\title{
OS MUROS DA CIDADE
}

Dissertação apresentada ao Departamento de Filosofia e Teoria Geral do Direito da Faculdade de Direito da Universidade de São Paulo, como requisito para a obtenção do título de Mestre em Filosofia do Direito, sob a orientação do Professor Doutor Ari Marcelo Solon.

UNIVERSIDADE DE SÃO PAULO

FACULDADE DE DIREITO

SÃO PAULO 


\section{Agradecimentos}

Agradeço a meus pais pelas oportunidades e suporte sem os quais este trabalho simplesmente não seria concretizado; ao Prof. Dr. Ari Marcelo Solon, por sua orientação inspiradora e pela confiança depositada em minha pesquisa; ao Prof. Dr. Samuel Rodrigues Barbosa e ao Prof. Dr. Guilherme Assis de Almeida, pelas valiosas sugestões dadas por ocasião da avaliação do projeto de qualificação; a Marlene Richter, que gentilmente providenciou cópias de obras às quais de outra maneira eu não teria acesso; a Wilma Lauer, por todo o incentivo, compreensão e admiração; a todo o corpo docente e equipe do I Curso de Especialização em Estudos Clássicos da Universidade de Brasília - Cátedra UNESCO/Archai, por sua importante contribuição para o meu aprofundamento nos estudos da Antiguidade; a Bruno Contini Soeira, pelo grande auxílio prestado nas atividades de monitoria ao longo do desenvolvimento da pesquisa e pelas entusiasmadas discussões filosóficas; e a todos os amigos que testemunharam o processo de desenvolvimento desta pesquisa. Koıvò $\tau \dot{\alpha}$ $\varphi \imath \lambda \omega \hat{\omega} v$. 
Não o interior desta esfera, que permanece oculta e sem o significado público, mas a sua aparência externa é importante também para a cidade, e surge na esfera da cidade sob a forma de limites entre uma casa e outra. A lei era originalmente identificada com esta linha divisória que, em tempos antigos, era ainda na verdade um espaço, uma espécie de terra de ninguém entre o privado e $o$ público, abrigando e protegendo ambas as esferas e ao mesmo tempo separando-as uma da outra. É verdade que a lei da polis transcendia esta antiga concepção da qual, no entanto, retinha a importância espacial original. A lei da cidade-estado não era nem o conteúdo da ação política (a ideia de que a atividade política é fundamentalmente o ato de legislar, embora de origem romana, é essencialmente moderna e encontrou sua mais alta expressão na filosofia política de Kant) nem um catálogo de proibições, baseado, como ainda o são todas as leis modernas, nos "Não Farás" do Decálogo. Era bem literalmente um muro, sem o qual poderia existir um aglomerado de casas, um povoado (asty), mas não uma cidade, uma comunidade política. Essa lei de caráter mural era sagrada, mas só o recinto delimitado pelo muro era político. Sem ela, tão impossível haver uma esfera política como existir uma propriedade sem uma cerca que a confinasse; a primeira resguardava e continha a vida política, enquanto a outra abrigava e protegia o processo biológico vital da família. 


\title{
Resumo
}

\begin{abstract}
A atividade legislativa na Antiguidade tem significado cósmico, uma vez que lida com a organização do espaço habitado pelo ser humano. A prática política foi situada sob a proteção concreta dos muros da cidade e da lei. Este trabalho pretende demonstrar a função da legislação e dos legisladores na conformação do espaço urbano grego e romano.
\end{abstract}




\begin{abstract}
Lawgiving in Antiquity has a cosmic meaning, since it deals with the organization of space inhabited by human being. Political practice has been put under concrete protection of the walls of the city and the law. This work aims to demonstrate the role of law and lawgivers on forming Greek and Roman urban space.
\end{abstract}




\section{Résumé}

L'activité législative dans l'Antiquité a sens cosmique, puisqu'elle traite de l'organisation de l'espace habité par l'être humain. La pratique politique a été placée sous la protection des murs de la cité et de la loi. Ce travail vise à démontrer la fonction de la loi et des législateurs dans la formation de l'espace urbain grec et romain. 


\section{Sumário}

RESUMO

ABSTRACT

RÉSUMÉ

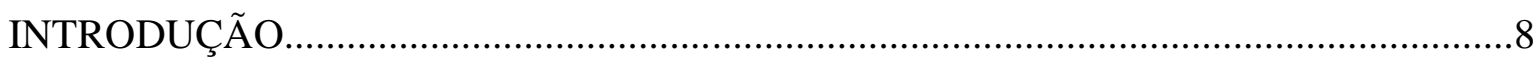

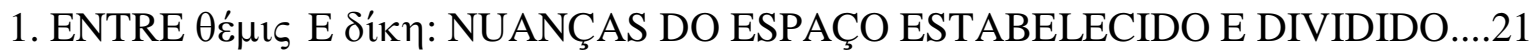

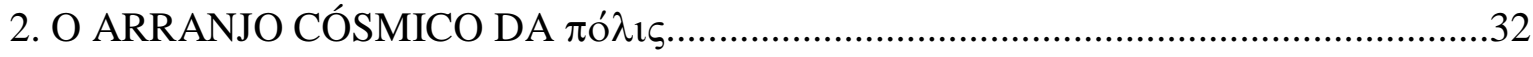

3. TRÊS RELATOS CÓSMICOS: COSMOLOGIA, ARQUITETURA E

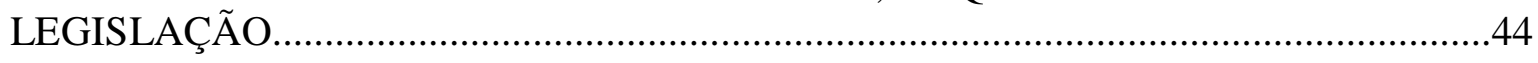

4. OS CENTROS DO COSMO: A ÁGORA E A ACRÓPOLE..........................................71

5. A CRIAÇÃO RELIGIOSA DO ESPAÇO NO DIREITO ROMANO............................91

CONCLUSÃO

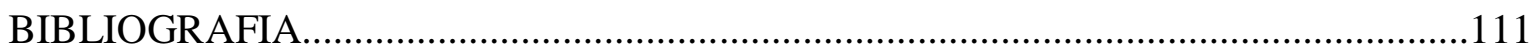




\section{Introdução}

Proferir palavras e realizar ações. Este foi o objetivo da educação do herói grego Aquiles, segundo nos informa o seu mentor, Fênix (Ilíada, 9, 443). Neste verso já se enuncia a dualidade da virtude guerreira, a $\alpha \rho \varepsilon \tau \eta \dot{n}$ que se manifesta como grandeza tanto no campo de batalha quanto na ágora, quando o guerreiro se levanta para falar no centro do $\lambda \alpha \alpha_{o}$, a assembleia de nobres reunida em círculo ao seu redor. Vir a público revela a ânsia de revelar-se digno de distinção em uma dimensão marcada justamente pelo caráter sublime, pela superioridade em relação a todos os aspectos ordinários da vida. A aparição e a convivência entre iguais não concerne às mesquinhas dificuldades da sobrevivência. ${ }^{1}$

Portanto, do ponto de vista da satisfação das necessidades humanas elementares, a política pode ser entendida como uma atividade fútil. Tal caráter de futilidade não significa que a política se trate de um capricho de homens desocupados - ao contrário, os gregos entendiam que apenas a aptidão para agir e falar entre iguais no espaço público conferia a verdadeira dignidade humana - mas que a vida política não dá conta das condições biológicas que constrangem o ser humano cotidianamente. Além de fútil, a atividade política se trata ainda de uma prática potencialmente perigosa, pois seus desdobramentos são imprevisíveis e ilimitados, sendo impossível traçar antecipadamente a forma como se desenvolverão os eventos no espaço público.

Considerada a política uma atividade fútil e perigosa, de início apenas um número bastante limitado de atores eram nela admitidos, de modo que a ascensão ao espaço privilegiado da discussão dos negócios públicos significava, implicitamente, a superação das preocupações relativas às necessidades materiais da sobrevivência. Isto se deve ao fato de que o indivíduo que agia politicamente, isto é, o cidadão, dispunha do controle sobre as atividades de outros, estes, sim, encarregados da produção dos bens necessários à manutenção da vida. Tais eram as pessoas compreendidas no âmbito da vida doméstica familiares e escravos - submetidas à necessidade, o que fazia da vida familiar (de famulus, "escravo") o lócus da vida privada - privada de cidadania e de discurso, apenas existentes

\footnotetext{
${ }^{1}$ ARENDT, Hannah. A condição humana. $10^{\mathrm{a}}$ ed. Rio de Janeiro: Forense. 2007, p. 34; JAEGER, Werner. Paidéia: a formação do homem grego. $3^{\text {a }}$ ed. São Paulo: Martins Fontes. 1994, pp. 30, 50-54.
} 


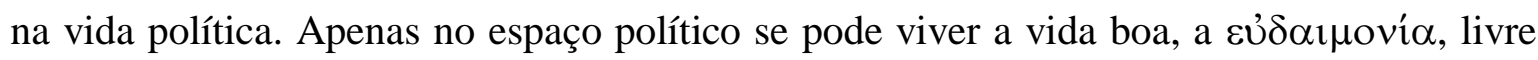
da violência que submete todos aqueles que, tolhidos da capacidade de deliberar e da possibilidade de fazer algo memorável, se ocupam precipuamente da sobrevivência. Por se tratar de um espaço de aparição entre iguais, a política não pode admitir em sua consideração os problemas decorrentes das necessidades humanas, pois sua satisfação se dá por meio de atividades fundadas na desigualdade entre as pessoas. ${ }^{2}$

O mando na vida doméstica, de maneira totalmente oposta à vida política, é baseado na desigualdade e nas necessidades da subsistência. Com efeito, Aristóteles, no primeiro livro da Política, argumenta que a vida doméstica está assentada em relações naturais: a união entre os sexos, para a satisfação do desejo natural de procriação; e a relação entre senhor e escravo, que o Estagirita pretende derivar, em sua essência, da natureza, embora admita que possa haver casos em que a escravidão se sustente exclusivamente em uma convenção legal. Tal relação de escravidão por força das leis ocasiona uma situação imperfeita, pois não propicia a realização da $\varphi \imath \lambda i ́ \alpha$ própria da relação de servidão, uma vez que o critério legal não leva em consideração o fato de a qualidade de senhor ou de escravo ser um atributo da alma do indivíduo.

Segue o filósofo, para aduzir que a propriedade integra a família na medida em que serve para garantir a manutenção da sobrevivência. Sob esse aspecto, o escravo se insere na propriedade como um instrumento, superior aos demais instrumentos, pois se trata de um instrumento capaz de agir por si, no que se diferencia da propriedade inanimada, que deve ser operada passivamente para os fins do uso ou da produção.

Com isso, Aristóteles quer demonstrar que, contrariamente ao que sustentavam muitos, entre a condução da família e do Estado não havia apenas uma diferença de grau, mas verdadeira distinção qualitativa, uma vez que em um caso se trata do governo sobre homens livres e iguais, enquanto no outro se tem o governo sobre aqueles que são, por natureza, escravos (Política, 1255b).

As atividades no âmbito da família, por mais penosas que fossem, destinavam-se à obtenção de produtos com a finalidade exclusiva de imediato consumo por meio dos processos biológicos. Voltados inteiramente à satisfação do metabolismo, os meios de

\footnotetext{
${ }^{2}$ ARENDT, p. 46; FerRAZ JR., Tércio Sampaio. Introdução ao estudo do direito: técnica, decisão, dominação. $4^{a}$ ed. São Paulo: Atlas. 2003, pp. 23-24.
} 
subsistência, uma vez utilizados, desaparecem. Nisso, a bem da verdade, a compreensão da vida privada se aproximava da concepção da atividade política, pois a ação no espaço público era notável por sua fugacidade, qualidade decorrente de seu caráter exclusivamente oral, do qual não deriva nenhuma evidência material direta, nenhum vestígio permanente. Nesse aspecto, à vida privada (fonte da subsistência humana) e à vida política (fonte da dignidade humana) se contrapõe a esfera da ars ou $\tau \dot{\varepsilon} \chi \nu \eta$, o conhecimento técnico, referente à manipulação dos elementos naturais com o escopo de obtenção de produtos de persistência mais ou menos perene. ${ }^{3}$

O mundo da técnica é o mundo da fabricação voltada a fins, da instrumentalização da natureza como fonte de bens, inclusive de outros instrumentos, ampliativos do alcance da própria técnica. Eis o espaço em que operam o carpinteiro, o oleiro, o ourives, o ferreiro, o arquiteto...

... E também o legislador, cuja atividade resulta em um produto permanente, que é a própria lei. Como atividade imprevisível, a política não é capaz de garantir o estabelecimento de diretrizes estáveis para o seu próprio desenvolvimento. Instados à contínua superação de seus pares e de si próprios, os homens tendem a se exceder e cometer atos desmedidos, a ư $\beta \rho ı \varsigma$, que fazem da política uma prática perigosa. Em muitos casos, a cidade atribuiu a prerrogativa de elaborar leis, em momentos de instabilidade política, a indivíduos eles próprios desprovidos de qualquer influência política, muitas vezes membros da classe média ascendente ou até mesmo estrangeiros, o que não deve ser visto como contraditório, em razão da natureza técnica, e não política, que se atribuía à atividade legislativa. Diante do quadro de potencial desestruturação da vida pública, a perenidade de produtos específicos da técnica - a lei, as fronteiras e muros do espaço público, os limites da propriedade privada - conferiam ao ambiente em que se desenrolava a atividade política condições para uma conformação relativamente estável, criavam um mundo comum que sobrevivia aos próprios homens e dava testemunho de suas ações e de sua aparição no espaço público. ${ }^{4}$

Contrariamente ao que se dá na esfera política, a produção no âmbito da $\tau \dot{\varepsilon} \chi v \eta$ é orientada segundo finalidades bem definidas. Os resultados da elaboração técnica podem ser, portanto, objeto de indagação quanto à sua finalidade e funcionalidade, o que seria

\footnotetext{
${ }^{3}$ FERRAZ JR., p. 24.

${ }^{4}$ ARENDT, pp. 201-205; GAGARIN, Michael. Early greek law. $1^{\text {st. }}$. ed. Berkeley: University of California. 1989, pp. 59-60.
} 
impensável de se procurar entre as motivações da ação política. Outra diferença entre a técnica e a política está no fato de que aquela se fundamenta precipuamente em um ato de violência contra a natureza, que precisa ser alterada para que o mundo das coisas humanas seja criado. ${ }^{5}$

A intencionalidade da atividade legislativa está em propiciar um substrato de condições minimamente estáveis ao exercício político. Essa é a razão de ser da $\pi$ ódı grega. Trata-se de assegurar um lugar definitivo, com uma estrutura adequada, para o desempenho da vida pública. A $\pi$ ó $\lambda ı \varsigma$ se acomoda entre seus muros e leis, que não são produtos políticos, mas elementos pré-políticos, condicionantes da atividade política propriamente dita, que não se realiza em construções e códigos legais, mas na aparição e na palavra proferida entre iguais. Enquanto o herói homérico precisava do aedo para continuamente reviver seus grandes feitos por meio da poesia - que é uma forma de $\tau \varepsilon \dot{\chi} \chi \eta$

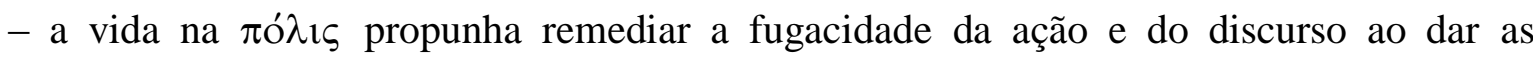
condições materiais para que os feitos dos indivíduos adquirissem a almejada imortalidade, por meio da $\tau \dot{\varepsilon} \chi \vee \eta$ do construtor e do legislador, eliminando a necessidade de continuamente se buscar realizar o extraordinário, que torna a vida em sociedade insustentável. $^{6}$

A tradição literária nos mostra, com a Ilíada, o estado de coisas predominante no período anterior ao surgimento daquele modelo de organização social, ao retratar o prevalecimento de um modo de vida essencialmente apolítico. Ao contrário do que se possa porventura imaginar, referido caráter apolítico da sociedade homérica não decorre, em essência, da situação de déficit democrático inerente a uma comunidade aristocrática de guerreiros. De acordo com Jaeger, os pressupostos da cultura da nobreza seriam a vida sedentária, a posse de bens e a tradição. Ora, tais características, por si sós, não constituem empecilho à instalação de algum grau de representatividade. ${ }^{7}$

Com efeito, há que se recordar a opinião segundo a qual as deliberações dos príncipes aqueus reunidos em conselho consistiriam o germe da democracia grega do séc. $\mathrm{V}$, com a qual, vale repisar, não contrastam os aspectos culturais aristocráticos enunciados por Jaeger. Pelo contrário, a democracia grega deve ser inserida, no plano deste autor, em um movimento maior de continuidade dos valores aristocráticos.

\footnotetext{
${ }^{5}$ ARENDT, pp. 152-157.

${ }^{6}$ ARENDT, pp. 205-211.

${ }^{7}$ JAEGER, pp. 37-60.
} 
Antes disso, a apolitia característica da cultura descrita por Homero é decorrente da falta de instituições que acomodassem firmemente a contínua busca pela confirmação da

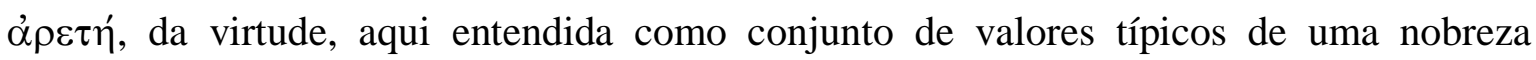
cavalheiresca. A contínua necessidade de busca do prêmio devido à excepcionalidade pessoal, à excelência guerreira, implicava a ânsia constante de reconhecimento social. Os nobres devem demonstrar a todo o momento, em tudo o que fizerem, sua condição de

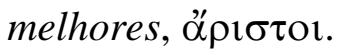

De fato, é notável que o grande evento digno da atenção do poeta da Ilíada seja a cólera desmedida de Aquiles em razão de se achar o herói privado de sua cativa, o butim

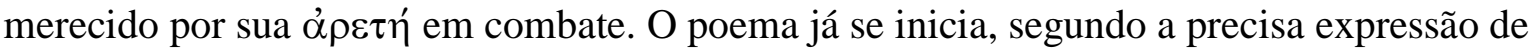
Horácio, in medias res. A guerra de Troia é apenas o pano de fundo para aquele problema, não se ocupando o poeta de suas causas nem de seu desfecho. ${ }^{8}$

Semelhante mentalidade realmente não pode prover meios para a obtenção de verdadeira estabilidade social. Os indivíduos se ocupam exclusivamente de atingir as possibilidades extremas da condição humana, o que não permite o desenvolvimento da vida política. Segundo ensina Cornelli, em suas aulas na Universidade de Brasília, a necessidade de busca de um parâmetro de estabilidade no mundo homérico pode ser vista como o fator fundamental para o surgimento da filosofia: a filosofia surgiu fora dos muros de Troia.

Nesse contexto, a $\tau \dot{\varepsilon} \chi \vee \eta$ propiciaria padrões operativos para a busca da excelência, fora de um quadro exclusivo de realização de feitos guerreiros. Talvez da mesma forma que a boa éris, por sua característica de fomentar o trabalho, seja apresentada por Hesíodo como uma motivação legítima do intento de superar a prosperidade do vizinho, a $\pi$ ó $\lambda \iota \varsigma$

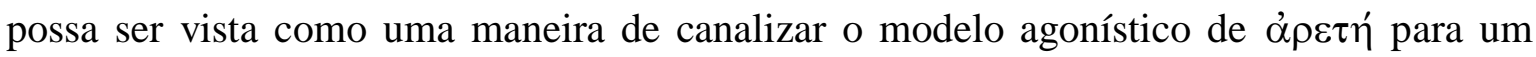
contexto não destrutivo.

Os gregos rivalizavam intensamente, a ponto de as referências às suas inclinações agonísticas se tornarem lugar-comum entre os modernos. A disputa por um mesmo cargo público ( $\tau \dot{\varepsilon} \lambda \mathrm{o}$ ) podia até mesmo prejudicar as relações de amizade, o que leva Aristóteles ao extremo de afirmar, nos Magna moralia, que a $\xi \varepsilon v \imath \kappa \eta ́$, o vínculo entre estrangeiros, pode ser o tipo mais duradouro de amizade, por se dar entre integrantes de corpos políticos

\footnotetext{
${ }^{8}$ JAEGER, pp. 73-76; PEREIRA, Maria Helena da Rocha. Estudos de História da Cultura Clássica. S. n. Lisboa: Calouste Gulbenkian. 1984, vol. I, p. 67.
} 
distintos. De qualquer modo, a $\pi$ ódıৎ logrou, no mais das vezes, manter a condição de normalidade de um conjunto estável de relações complexas, no qual se entretecem os vários laços e obrigações em face da família, dos vizinhos, da propriedade da terra e da cidadania.

Portanto, uma vez que se prestam à mesma finalidade de desenho estrutural do espaço ocupado pelo homem mediante atos de manipulação técnica da natureza, legislação e atividades como arquitetura, urbanismo e agrimensura podem ser analisadas conjuntamente, sob a categoria da $\tau \varepsilon^{\prime} \chi \nu \eta$, o que permite uma abordagem que evidencie a transcendência existente, tanto em relação aos métodos quanto no que se refere às finalidade e usos, entre tais atividade análogas.

Dessa forma, em termos arendtianos, se expressa Ferraz Jr. ${ }^{10}$ :

\begin{abstract}
Assim, na Antiguidade, pode-se dizer: a legislação enquanto trabalho do legislador não se confundia com o direito enquanto resultado da ação. Em outras palavras, havia diferença entre lex $e$ jus na proporção da diferença entre trabalho $e$ ação. Desse modo, o que condicionava o jus era a lex, mas o que conferia estabilidade ao jus era algo imanente à ação: a virtude do justo, a justiça.
\end{abstract}

Essa virtude da justiça aduzida por Ferraz Jr. não é, nesse sentido, a preocupação primordial do legislador. A lei, produto de seu ofício, representa um domínio originário sobre o espaço, demarcando-o, edificando-o. A preocupação ética sobrevém apenas em etapa muito posterior da evolução social antiga, como será apresentado ao longo da investigação.

O objetivo deste trabalho consiste em promover uma reflexão sobre o papel desempenhado pelas legislações como elementos de conformação do espaço habitado pelo homem, entre os antigos gregos e romanos. À luz da inclusão da lei entre as demais atividades consideradas pelos gregos como pertencentes à categoria da técnica, o fazer legislativo deve ser entendido, de um lado, em estreita consonância com as demais artes que regem a divisão e construção no espaço, notadamente a arquitetura e o urbanismo; e de outro, em função dos saberes religiosos e filosóficos que, ao discorrerem sobre a estrutura do espaço e o lugar do homem no cosmo, informaram a atividade legislativa. O mesmo se

\footnotetext{
${ }^{9}$ Konstan, David. A amizade no mundo clássico. $1^{\text {a }}$ ed. São Paulo: Odysseus. 2005, pp. 131-132.

${ }^{10}$ FERRAZ JR, p. 24.
} 
diga dos romanos, que, embora não tenham aparentemente sedimentado todas aquelas atividades segundo uma tipologia específica, desempenharam-nas de forma condizente com sua racionalidade conformadora do espaço construído e habitado pelos homens, tendo resolvido na religião o problema da violência inerente à manipulação da natureza.

Dito isso, esclareça-se desde já que o fragmento de Heráclito segundo o qual a lei deve ser defendida como se fossem os muros da cidade (fr. 44 DK) não deve ser entendido como um velho dito "metafórico" de um filósofo proverbialmente obscuro. O fragmento não encerra a figuração de um conceito abstrato, e sim a verdade da analogia entre a lei e os muros como instrumentos de conformação do espaço político. A legislação e a construção são tidas como gêmeas univitelinas, concebidas por força de uma compreensão bastante sofisticada e lúcida desenvolvida pelos antigos acerca do funcionamento das sociedades em que viveram. Qualquer interpretação que aceite menos do que isso, em favor de explicações que recorram à ideia de alegoria no pensamento primitivo traz consigo a marca de um esquematismo positivista-evolucionista.

Menos ainda se deve cair no pecado predileto da dogmática jurídica, que consiste em pretender enxergar em institutos da Antiguidade a genealogia de homônimos modernos. Uma investigação acerca das repercussões da lei sobre a disposição do traçado urbano na Antiguidade não pode ser vista como um antecedente de eventos tais como a adoção de legislação acerca do ordenamento urbano nas cidades contemporâneas, que de modo geral atentam meramente aos problemas de otimização das atividades econômicas e do fluxo de circulação nesses locais. A disposição dos elementos urbanos entre os antigos traduz, conforme se verá adiante, sua própria compreensão espacial do direito, ao passo que os aspectos comerciais, higiênicos e militares são muitas vezes deixados em segundo plano.

O espaço não parece ser uma categoria muito estudada em conexão com o fenômeno jurídico, e quando o é, geralmente se insere em alguma reflexão sobre o problema moderno da soberania estatal, do âmbito espacial de validade. Muito mais abundante é a atenção dispensada pela jusfilosofia e pela teoria geral do direito à experiência do tempo. Gostaria de recordar, a respeito disso, que os gregos compreenderam o tempo geometricamente. Desde a dialética de Zenão, pelo menos, até a física aristotélica, o tempo é muitas vezes experimentado como quanta espaciais, aspecto enxergado por Heidegger, à sua maneira, já em Anaximandro, conforme será exposto oportunamente. No momento adequado, serão expostas, ainda, as consequências temporais das reformas 
operadas por Clístenes no espaço geográfico de Atenas. Lembre-se, por fim, a gama de consequências jurídicas advindas do entendimento circular do tempo plasmado no eterno retorno da Moira nas tragédias, o que não poderá, evidentemente, constituir objeto de estudo pormenorizado neste trabalho.

É visível que muito da inspiração para este trabalho decorre do contato com a obra de Hannah Arendt, A condição humana, que tem por viga mestra o retrato das diversas atividades humanas em conformidade com a tipologia política - técnica - vida privada pouco antes apresentada. Contudo, optei por não reproduzir em minha argumentação a nomenclatura consagrada para esta classificação, que diz, respectivamente, da ação, do trabalho e do labor, uma vez que tais denominações não apenas não refletem o uso nas fontes literárias, como por vezes o contradizem.

Aristóteles, por exemplo, ao discorrer sobre a escravidão no primeiro livro da Política - trecho que mencionava pouco acima - chama a atividade do escravo de $\pi \rho \alpha ́ \xi ı \varsigma$, o que invalida a restrição vocabular rigorosa de ação às atividades políticas. Por seu turno, trabalho é proveniente de tripalium, termo que tem inteiramente outro sentido na Antiguidade. $\mathrm{Na}$ nomenclatura arendtiana, o trabalho corresponde de forma aproximadamente adequada àquilo que os gregos denominaram $\pi$ oínбıs.

A pesquisa ora apresentada trata daqueles a quem recorrentemente chamei "os antigos". Com esse termo, quis englobar as civilizações dos antigos gregos e os romanos. O recorte não se deveu a uma necessidade de permanecer fiel à tradição de estudos que abarca ambas as culturas sob o mesmo signo de uma "cultura clássica", "berço da civilização ocidental", que tantas vezes resultou na indevida romanização dos gregos, como já Nietzsche acusava. Não busco em momento algum aí rastrear as origens das instituições ocidentais contemporâneas, e sim evidenciar um seu sentido amplamente ignorado, partilhado por ambos os povos.

A evidência para esse sentido esquecido foi buscada no estudo linguístico. Não se trata do conhecimento das línguas latina e grega, mas da investigação sobre os sentidos subjacentes ao seu vocabulário, tendo-se como pressuposto de trabalho o pertencimento de ambos os povos à família linguística indo-europeia, da qual herdaram a essência de sua visão de mundo. O estudo lexical não é suficiente, mesmo porque em nada acrescentaria ao nosso conhecimento sobre a terminologia e o pensamento jurídico antigos discursar 
exaustivamente acerca das ocorrências da palavra lex, por exemplo, tendo como parâmetro nosso próprio entendimento de lei. Há que se ir até níveis mais profundos de análise, para apenas então encaminhar o estudo do léxico propriamente dito.

A base para a análise lexical das línguas indo-europeias é a raiz. Muito se tem discutido a respeito da sistematização dos aspectos estruturais e fonológicos envolvidos na reconstrução de tais raízes. Émile Benveniste, cuja obra forneceu a maior parte dos radicais apresentados neste trabalho, defende que todas as raízes originárias do proto-indo-europeu poderiam ser reduzidas à forma $* C e C$-, ou seja, um monossílabo composto de duas consoantes quaisquer, uma inicial e outra final, com uma vogal $e$, de modo que todos os desenvolvimentos posteriores a partir da raiz seriam devidos a processos de alargamento daquela sílaba primitiva ou à junção de afixos. ${ }^{11}$

Há muita controvérsia quanto à validade da hipótese aventada por Benveniste, especialmente no que diz respeito à sua tentativa de estabelecer a forma reconstituída dos radicais. De fato, há evidência de raízes que fogem à forma prevista pela sistemática do linguista francês. Ainda que, de acordo com Clackson, tais exceções constituam número bastante reduzido, devo asseverar que a reconstrução fonológica exata dessas formas é um problema que foge às diretrizes do trabalho. Uma vez identificada a procedência dos termos desde uma mesma raiz, importa muito mais a apresentação dos sentidos herdados do que a especulação morfológica. Já no primeiro capítulo é apresentada, entre outros exemplos possíveis, uma raiz rta discutida por Cornford - forma que contraria por completo o esquema de Benveniste. ${ }^{12}$

O que realmente tem interesse para a presente discussão, diga-se uma vez mais, é a compreensão dos aspectos semânticos que, desde a raiz comum, abarcam os grupos de palavras estudados. Nisso efetivamente avulta a importância de Benveniste, responsável pela elaboração de um minucioso catálogo de interpretações de termos das diversas línguas indo-europeias a partir do estudo de suas raízes. O elevado valor do trabalho de investigação semântica de Benveniste se deve à sua concepção contrária ao procedimento tradicional de reconstrução de sentidos pelos estudiosos modernos, os quais operavam mediante a abstração ou a simples acumulação dos significados encontrados para as palavras derivadas de cada raiz. Benveniste propôs outra abordagem metodológica, que

${ }^{11}$ ClaCKSON, James. Indo-European linguistics: an introduction. $1^{\text {st }}$. ed. Cambridge: Cambridge University. 2007, pp. 65-67.

${ }^{12}$ Clackson, pp. 67-68. 
enfatiza o exame detalhado das palavras derivadas no seu contexto textual e social específico, de modo a demonstrar não os desenvolvimentos semânticos paralelos dos termos, mas a presença contínua de um significado prototípico subjacente da raiz durante a criação dos termos derivados em cada língua. ${ }^{13}$

No dizer do próprio Benveniste ${ }^{14}$ :

\begin{abstract}
Les comparatistes pratiquent donc deux opérations dont la première est une abstraction consistant à évacuer des significations historiquement attestées ce qu'elles ont de concret, le résidu vague ainsi obtenu étant posé comme le sens premier - la seconde, une juxtaposition qui additionne tous les sens ultérieurs, mais qui n'est qu'une vue de l'esprit, sans appui dans la réalité des emplois. En fait un sens comme celui que nous cherchons ne peut être atteint que par une analyse en profondeur de chacune des valeurs historiquement constatées. Des notions simples et distinctes comme "juger", "guérir", "gouverner" ne font que transposer dans notre langue un système de signification autrement articulé. Ce sont toutes les composantes d'un sens global qu'il s'agit de faire apparaître en vue de restaurer l'unité fondamentale de la signification.
\end{abstract}

Com a orientação linguística conferida a este estudo, espero ter atingido dois importantes objetivos. Primeiramente, há que se reconhecer a necessidade de integração entre a reflexão histórica sobre o direito, como promovida no âmbito do próprio estudo acadêmico jurídico, e os estudos que abordam as fontes jurídicas antigas sob o aspecto linguístico e filológico, que muito têm ainda a revelar aos estudiosos da Filosofia do Direito, do Direito Romano e da História do Direito.

Em segundo lugar, a análise das raízes linguísticas propicia o estabelecimento de uma genealogia dos valores jurídicos que permite abordar os institutos estudados enquanto fenômenos, ao menos vislumbrando algo de sua vitalidade, tal como entendida por aqueles que viveram sua realidade. A apresentação dos valores semânticos do vocabulário usado por gregos e romanos é a forma mais rigorosa que pude encontrar para apresentar o objeto fenomenologicamente, por meio de uma construção dialógica de concepções hodiernamente subvertidas, olvidadas, sem que isso incorresse em petição de princípio ou acarretasse uma reconstrução teatralizada dos sentidos.

\footnotetext{
${ }^{13}$ CLACKSON, pp. 191-194.

${ }^{14}$ BenVEniste, Émile. Le vocabulaire des institutions indo-européennes. S. ed. Paris: Minuit. 1969, vol. 2, p. 127.
} 
Para isso seria inútil - além de impraticável - um catálogo exaustivo da ocorrência dos termos, com longas discussões sobre análise textual. Uma vez estabelecido o sentido geral do pensamento jurídico antigo a partir das análises do primeiro capítulo, pretendi o mais possível manter um tom ensaístico, recorrendo à evidência dos desenvolvimentos históricos das instituições mais do que à erudição.

A origem da linguagem não é um problema do qual tem se ocupado a linguística. ${ }^{15}$ Do mesmo modo, não me preocupei em oferecer uma conceituação prévia do que sejam instituições jurídicas para daí buscá-las no vocabulário, pois são as definições préconcebidas que no mais das vezes têm conduzido a equívocos de interpretação. Deixei que os próprios idiomas fornecessem, por meio da análise semântica de suas raízes, os sentidos do direito.

À vista disso, evidente que a análise dos radicais linguísticos que é propiciada pelo estudo comparativo do vocabulário das diversas línguas indo-europeias não se exaure em si mesma, mas proporciona a oportunidade para uma abordagem filológica dos problemas. Se a linguística consiste no estudo científico da linguagem, para o qual a análise literária se apresenta como um valioso instrumental, a filologia trata do estudo global do texto, permitindo, por meio de sua literatura, uma melhor compreensão da civilização em seu contexto. A análise linguística e suas aplicações filológicas são o que mais se aproxima de uma metodologia para este trabalho. ${ }^{16}$

A pesquisa não se encerra na análise da língua e da literatura, uma vez que permitirá desenvolver debates próprios da Filosofia do Direito, concernentes ao problema da lei e de sua dualidade técnico-política; bem como do lugar da justiça no pensamento e na prática jurídicos. Ademais, a discussão desenvolvida confere o ferramental para a abordagem de filósofos do direito contemporâneos que se dedicaram em sua obra à compreensão do direito antigo.

Nesse sentido, outra elaboração teórica que, se não chega a constituir uma diretriz metodológica, em muito inspirou a condução da presente investigação, é aquela enunciada pela vertente escandinava do realismo jurídico, conforme os desenvolvimentos realizados por Axel Hägerström, o pensador sueco que tanto se bateu contra o entendimento

${ }^{15}$ Perrot, Jean. La linguistique. $2^{\text {ème }}$. éd. Paris: Presses universitaires de France. 1957, pp. 95-97.

${ }^{16}$ CAmbraiA, César Nardelli. Introdução à crítica textual. $1^{\mathrm{a}}$ ed. São Paulo: Martins Fontes. 2005, pp. 13-18. 
modernizante - portanto, artificializado - conferido pelo pensamento jurídico tradicional às instituições do direito na Antiguidade, para as quais os modernos não raro se arrogam a condição de herdeiros e continuadores.

A investigação é principiada com o capítulo intitulado Entre $\theta \dot{\varepsilon} \mu \iota \varsigma$ e $\delta i ́ \kappa \eta:$ nuanças do espaço estabelecido e dividido, que se ocupa do estudo das raízes vocabulares que compõem os termos indo-europeus que se aproximam da noção de instituições jurídicas. Estudo intrigante por seus resultados, já que conduz à percepção de que todos aqueles radicais apresentam significados referentes à divisão e construção do mundo físico, enquanto não existe qualquer raiz que corresponda à noção abstrata de direito ou justiça.

O segundo capítulo, $O$ arranjo cósmico da $\pi o ́ \lambda \iota \varsigma$, retoma o estudo do vocabulário indo-europeu no ponto em que se encerra a discussão do capítulo precedente, para acompanhar, a partir de um fragmento atribuído ao filósofo pré-socrático Pitágoras, o desenvolvimento do sentido espacial de ordem subjacente às instituições jurídicas,

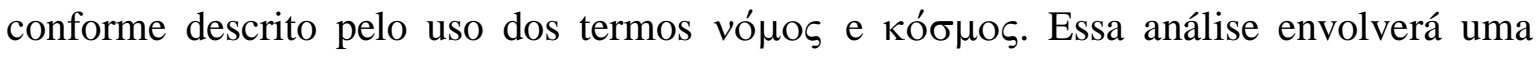
incursão pelo pensamento jusfilosófico do século XX, para apresentar a compreensão do termo vónos na obra de Carl Schmitt, autor que corrobora o significado espacial ora indicado.

Sobrevém o terceiro capítulo, Três relatos cósmicos: cosmologia, arquitetura e

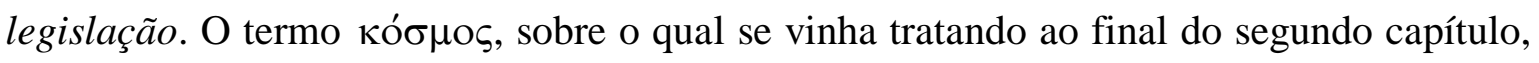
tornar-se-ia a expressão do primeiro grande problema tradicionalmente reconhecido como filosófico, no que cabe indagar sobre o componente cosmológico - no sentido filosófico do termo - da criação do espaço urbano. Apresento a instigante tese de Robert Hahn, autor que sustenta que a cosmologia dos primeiros filósofos milésios ascende em razão dos movimentos em curso na sociedade urbana da Jônia, sendo diretamente influenciada em sua linguagem e proposições pela racionalidade das práticas arquitetônicas introduzidas na região. Procuro demonstrar que a elaboração da cosmologia milésia sofre a influência não

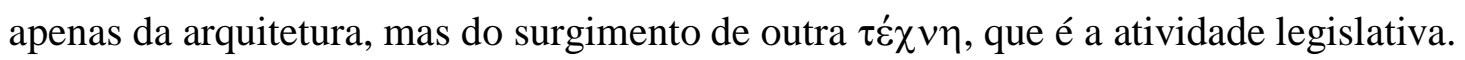

O quarto capítulo, Os centros do cosmo: a ágora e a acrópole, é aberto com a discussão dos sentidos cósmicos da legislação de Sólon. Partindo-se deste substrato, a principal consequência da investigação é o surgimento da proposta platônica de reformulação da cidade, que não deve ser compreendida como uma utopia de evasão, mas 
como um projeto sério em função de eventos históricos que sugerem a viabilidade de uma reforma política informada por doutrinas filosóficas, nomeadamente, os governos de inspiração pitagórica instalados na Magna Grécia e a reforma operada por Clístenes, em relação à qual o planejamento urbano platônico se coloca como um antípoda.

Finalmente, A criação religiosa do espaço no direito romano destoa dos demais capítulos em razão de ser a única parte do trabalho majoritariamente devotada à experiência romana da lei como organizadora do espaço. Essa assimetria se deve ao corte temporal realizado, pois tentei me ater aos primórdios da evolução da iurisprudentia, ao passo que o desenvolvimento do problema entre os gregos exigiu considerar período mais largo; mas também à peculiaridade dos romanos em face dos gregos, pois aqueles claramente experimentaram suas instituições, inclusive o direito, no sentido de uma forte religiosidade, muito mais inconstante entre estes, o que conduz a argumentação para um caminho mais afastado da identificação filosófica da lei como um elemento da técnica. A organização espacial visada pelos romanos atende à racionalidade própria da religião.

A religiosidade traduzida na consagração do espaço e o caráter mágico em que se envolvem as práticas jurídicas ritualísticas de Roma são aspectos que devem ser continuamente realçados, a fim de se combater os equívocos e anacronismos a que nos expomos hodiernamente com nossa tradição de estudos romanísticos. 


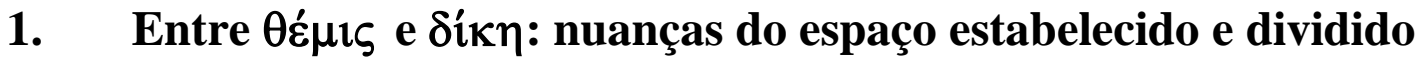

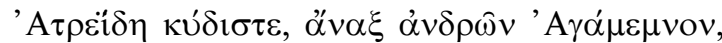

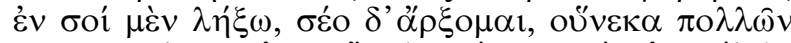

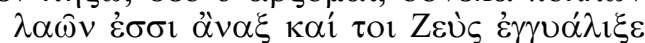

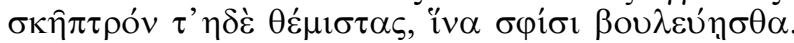 \\ Poderosíssimo filho de Atreu, Agamêmnon, rei dos homens, \\ Principiarei a falar por ti, pois de muitos \\ Rebanhos és rei, e Zeus te dotou de \\ Cetro e leis, a fim de que sobre eles exerças conselho.
}

Ilíada, 9,97 e ss.

Sob o nome de indo-europeus são agrupados povos dos mais diversos matizes étnicos, historicamente espalhados entre Gibraltar e os confins ocidentais da China, para não mencionar sua posterior ocupação nas Américas, na Oceania e em África. Não obstante, não são poucos os exemplos de paralelismo vocabular que evidenciam a comunhão linguística subjacente àquelas culturas. Essas inúmeras semelhanças estruturais e de léxico propiciaram um esforço científico de reconstituição de um idioma originário, matriz de todas as demais línguas do tronco, o proto-indo-europeu, cujo vocabulário é determinado conjecturalmente, mediante o recurso à noção, a um só tempo morfológica e semântica, de raízes ou radicais vocabulares.

Atualmente, tanto por sua representatividade em termos históricos quanto pelo volume de estudos realizados a seu respeito, o indo-europeu se inscreve entre as mais importantes famílias linguísticas conhecidas. Todos aqueles povos notavelmente apresentam elementos que demonstram a complexidade e variedade de seus modos de organização social, aspectos patentes em função da extensão e profundidade da projeção das instituições de suas culturas nos rumos da história da própria humanidade.

Curiosamente, no entanto, verifica-se a inocorrência de uma raiz indo-europeia que se preste, de maneira generalizada entre as línguas do grupo, à expressão da categoria do jurídico, enquanto uma instituição socialmente delimitada. Mesmo o bem conhecido termo latino ius ocorre apenas isoladamente, não se conhecendo palavras de mesma raiz em outros idiomas antigos deste grupo que sejam usadas no mesmo sentido atestado em latim. 
Ius provém de uma raiz que encerra a ideia de pronunciamento oral solene, verbalização sagrada, conforme outro termo daí proveniente, que se conservou entre nós: iurare, "jurar". $\mathrm{O}$ direito como ius surge da palavra proferida, por meio da fórmula, per concepta verba. $\mathrm{O}$ dicionarista extrai a etimologia de ius a partir de outra prática eminentemente oral: iubere, "ordenar", "dar ordem", "mandar". ${ }^{17}$

Mesmo entre as demais línguas itálicas, o termo ius é desconhecido no que toca à designação de instituições jurídicas: o osco, o úmbrio e o etrusco, em consonância com o que se dá também entre as línguas do ramo indo-iraniano, se valem da raiz *med- aí onde os romanos dizem ius. Termos derivados de *med- também se encontram no latim e, por consequência, entre nós; sempre, no entanto, com o sentido bem delimitado de um enunciado de autoridade acerca da medida das coisas: medida, medição, modo, moderação, modéstia, remédio, medicina. ${ }^{18}$

Ao passo que a raiz comum específica da noção do jurídico está ausente, é digna de nota a persistente associação entre as ideias de lei ou norma e de algo como uma percepção geral da ordem física ou do arranjo espacial, que se exprime por intermédio dos termos derivados da raiz ar, com a qual está relacionado o termo védico rta e o seu equivalente iraniano arta, cuja personificação resultou na divindade Arta, o deus védico da ordem cósmica. Segundo Cornford, trata-se de Asha, o princípio de disposição da boa ordem do universo. Posteriormente, no sânscrito clássico, essa raiz dará o termo ratu, que designa a ordem das estações, o ciclo do tempo, mas também a noção geral de regra ou norma. A família de palavras composta por rta - arta - ratu denota, portanto, a harmonia inerente ao cosmo, à relação entre deuses e homens; e aos homens entre si. ${ }^{19}$

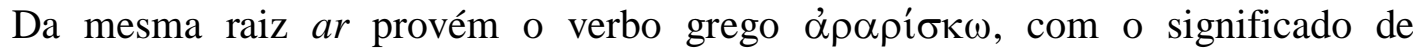
"ajuntar", "adaptar" ou "harmonizar". Em latim, por sua vez, há o notório termo ars, com o significado originário de "disposição natural", "qualificação", "talento". Veja-se, ainda, os vocábulos diversos que exprimem a noção de conjuntura, como as palavras para

\footnotetext{
${ }^{17}$ Benveniste, vol. 2, pp. 111-122; Saraiva, F. R. dos Santos. Dicionário latino-português. $11^{\mathrm{a}}$ ed. Rio de Janeiro: Garnier. 2000, vocábulos Jǔběǒ, ēs, jūssī, jūssǔm, bērě; Jūrō̄, ās, āvī, ātǔm, ārě; e Jūs, ūrǐs.

${ }^{18}$ Benveniste, vol. 2, pp. 123-132.

${ }^{19}$ Benveniste, vol. 2, pp. 99-100; CORNFORD, F. M.. From religion to philosophy: a study in the origins of Western speculation. $1^{\text {st }}$. ed. Princeton: Princeton University. 1991, pp. 172-177.
} 


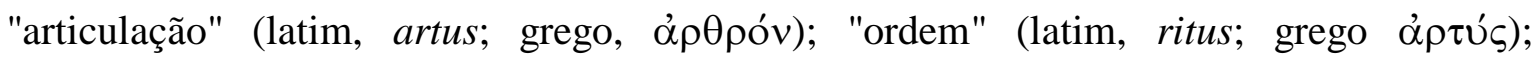

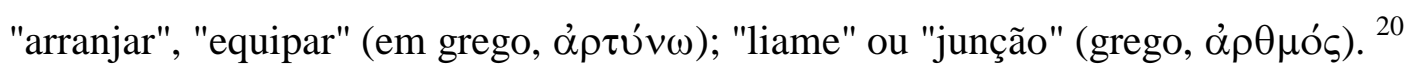

A ideia de harmonia presente na raiz ar, conforme o atestam os diversos exemplos apresentados, não remete de maneira específica à norma jurídica, encontrando-se esta contida em um conjunto muito mais extenso de experiências da ordem. Desse modo, cabe indagar se há termos que sirvam à designação mais específica da elaboração de normas de conduta, o que encontramos nos vocábulos que decorrem dos desdobramentos de determinadas raízes, a saber: *dhar-e *dhē, além daquele já mencionado, ius, que apresenta desenvolvimentos particulares, restritos ao latim.

Da raiz *dhar- se originou o dharma hindu, que deve ser compreendido à luz da religião védica original, cujos textos regulavam todos os atos sacrificiais do ministério dos sacerdotes brâmanes. Tal codificação aponta para o sentido do dharma enquanto conjunto de deveres ou obrigações. Não se trata de uma normatividade posta por um ato de vontade com o fito de realizar ou distribuir justiça e direitos, mas de determinação das obrigações correspondentes aos diversos nichos sociais: cada casta detinha seu próprio dharma. Mesmo o rei estava submetivo a um dharma próprio de sua condição, o qual não poderia transgredir. ${ }^{21}$

Originariamente, a raiz *dhar- significa "pegar com firmeza", tendo dela provavelmente resultado ainda as palavras latinas firmus e firmamentum (atente-se para a formação paralela em $m$ de firmus e dharma). Essa raiz guarda, portanto, a noção de "fixidez", "mantença".

Contudo, muito mais significativa para o problema em comento será a análise da evolução do radical *dhē-. Essa raiz tem o sentido originário de "pôr", ação que não se confunde com o mero colocar, deixar-se algo solto em algum ponto do espaço em determinada posição, mas de algo que é "estabelecido" de determinada maneira e com a marca da perenidade e da criatividade. ${ }^{22}$

Dessa raiz se origina a palavra dhāmman, que designa as regras do culto familiar de Mitra-Varuna, normas cúlticas efetivamente estabelecidas pela divindade. Veja-se o par de verbos facio e $\tau i \dot{\theta} \eta \mu \mathrm{l}$, ambos oriundos do radical em questão, que expressam as ações de

\footnotetext{
${ }^{20}$ BenVENiste, vol. 2, pp. 100-101.

${ }^{21}$ BeNVENisTe, vol. 2, p. 101

${ }^{22}$ Benveniste, vol. 2, pp. 101-102.
} 
"estabelecer", "fixar", "determinar", "instituir", "organizar", entre outras atestadas pertencentes ao mesmo campo semântico. Ora, aquele que estabelece algo é seu fundador, criador e, por consequência, seu dominador. Nesse sentido, o termo avéstico dāmi, "criador".

A variante dialetal dórica do grego antigo registra o termo $\theta \varepsilon \sigma \mu$ ó $\varsigma$, que quer dizer justamente "lei". Da mesma família terminológica, a palavra $\theta \varepsilon \dot{\varepsilon} \mu \varepsilon \theta \lambda \alpha$, oriunda do vocabulário da construção de edificações, a designar a "base", o "fundamento" do prédio. Esse é um termo já muito próximo à importante palavra $\theta \dot{\varepsilon} \mu \iota \varsigma$, o principal vocábulo para o fundamento homérico do direito.

Benveniste defende que a análise da relação estreita entre $\theta \varepsilon ́ \mu ı \varsigma$ e o já mencionado dhāmman permitiria delimitar o alcance da concepção de direito expressa por aquela palavra grega: tratar-se-ia de uma normatividade de âmbito intrafamiliar e de origem divina. Em favor dessa delimitação colocada por Benveniste a partir da análise comparativa dos termos, conte-se o exemplo aduzido pelo autor a respeito da descrição dos Ciclopes na Odisseia: desprovidos de qualquer forma de governo e de organização familiar extensa, nos moldes do $\gamma \varepsilon ́ v o s$ grego, tais monstros são chamados por Homero de

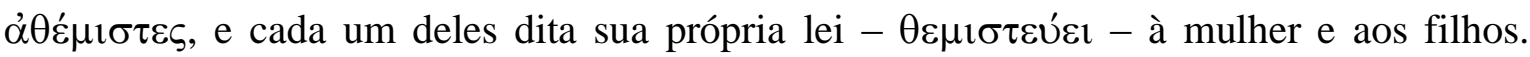
Desprovidos de $\theta \dot{\varepsilon} \mu \iota \varsigma$, esses Ciclopes realmente nada mais seriam do que uma horda de trogloditas. ${ }^{23}$

Aristóteles (Política, 1252b) cita essa passagem de Homero acerca dos Ciclopes para reforçar seu argumento de que a monarquia fora a forma de governo originária entre os gregos, decorrente do domínio natural do mais idoso sobre a família extensa. A primeira organização social se teria baseado na família.

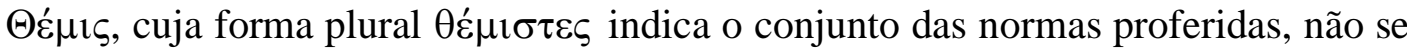
trata de regra arbitrariamente elaborada por um mortal, positivada, mas de uma prerrogativa da realeza, conferida diretamente pela divindade. A atribuição a Zeus não implica o reconhecimento de uma determinação divina do conteúdo das normas, mas tão somente a legitimação das disposições decorrentes da autoridade real, que se funda na própria divindade, o que resta sintetizado com meridiana clareza no trecho que serve de epigrafe a este capítulo, Ilíada, 9, 97. Gagarin sustenta que $\theta \dot{\mu} \mu 1 \sigma \tau \varepsilon \varsigma$ são "normas de

\footnotetext{
${ }^{23}$ Benveniste, vol. 2, pp. 102-105; GAGARIN, p. 106.
} 
comportamento", para em seguida discutir a atividade julgadora dos reis com apoio em um passo de Hesíodo (Teogonia, 85-86), que diz dos senhores exercerem o dom das musas,

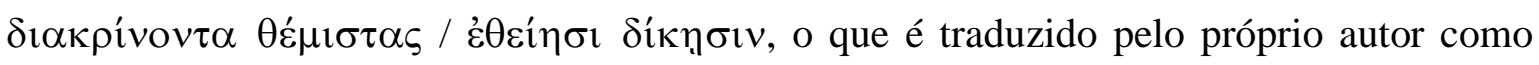
"deciding the proprieties with straight settlements". Para Gagarin, o dom das musas seria a capacidade de o rei falar de maneira criativa e persuasiva, o que denotaria o caráter de procedimento voluntário que este autor acredita se encontrar na origem do direito grego. Tudo isso soa contraditório, pois a resolução de controvérsias com base na intermediação voluntária de um julgador criativo, apto a persuadir os contendedores por meio do mútuo benefício decorrente de uma decisão engenhosa, deveria se basear essencialmente no consenso, e não na legitimidade conferida pela divindade. ${ }^{24}$

Embora erre ao se encaminhar para um entendimento não literal, mas metafórico, da ideia de fundamento subjacente à palavra em análise, vale assinalar que a literatura jurídica moderna tem oferecido suas próprias respostas à questão da etimologia de $\theta \varepsilon \dot{\varepsilon} \mu \iota \varsigma$.

Ehrenberg sustenta que a palavra tem sua origem remota na tradição cúltica dos deuses ctônios, pois $\theta \dot{\varepsilon} \mu ı \varsigma$ designaria, originariamente, o amontoado de pedras, a montanha oracular sagrada. Por sua vez, Ruipérez se opõe a essa explicação, ao afirmar que o termo em comento remeteria, na verdade, às pedras fixadas na ágora para servirem de assento aos anciãos reunidos em assembleia, onde proferiam decisões. ${ }^{25}$

A partir dessa breve síntese das posições, parece-me que Ehrenberg teve uma intuição acertada ao frisar a natureza religiosa de $\theta \varepsilon ́ \mu ı \varsigma$, fato que, além de estar completamente evidenciado em passos literários tais como aquele em epígrafe, harmonizase com aquele outro termo da mesma raiz, cuja comparação ensejou minha apresentação do problema, dhāmman, enquanto vocábulo de alta significação religiosa.

No entanto, a evolução etimológica proposta por Ruipérez vai além, ao deixar ver em $\theta \varepsilon ́ \mu ı \varsigma$ o significado da raiz originária, o seu entendimento como ato de criação, de estabelecimento duradouro em um lugar e de fundação de uma edificação.

Ironicamente, se a figura da ágora serve à reflexão sobre a essência de $\theta \varepsilon ́ \mu t \varsigma$, será justamente por meio da descrição da ágora, no passo da Ilíada em que o poeta descreve o desenho do escudo de Aquiles, que se encontrará o termo que, sempre de acordo com a

\footnotetext{
${ }^{24}$ Gagarin, pp. 24, 133.

${ }^{25}$ Solon, Ari Marcelo. Direito e tradição: o legado grego, romano e bíblico. S. ed. Rio de Janeiro: Elservier. 2009, pp. 75-78.
} 
interpretação de Benveniste, designa o direito que vige no âmbito contraposto a $\theta \dot{\varepsilon} \mu \imath \varsigma$, isto

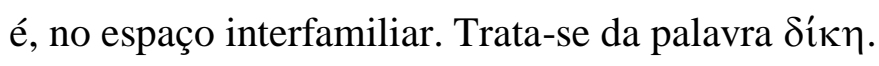

A passagem em questão (Ilíada, 18, vv. 497 e ss.) descreve o escudo no qual está representado o mundo e, em seu centro, a ágora, onde se desenrola um julgamento

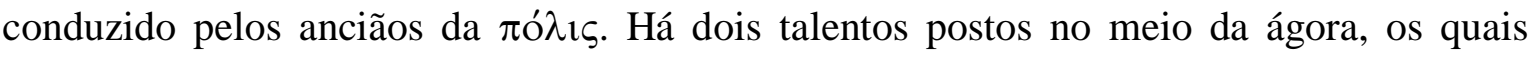

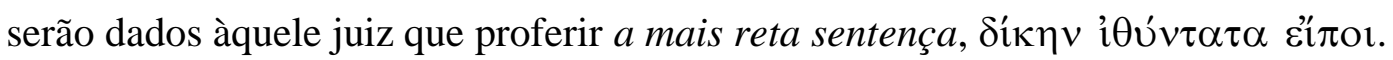

$\Delta i ́ \kappa \eta$ provém da raiz *deik-, que está relacionada ao verbo latino dico, o qual

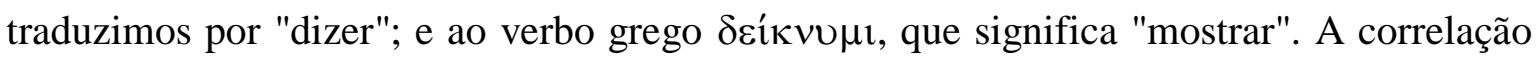
entre dizer e mostrar não pode se afigurar evidente à primeira vista, exigindo certo esforço de reconstrução dos sentidos. Para tanto, revela-se de grande utilidade refletir sobre a passagem homérica que se acaba de apresentar, em sua expressiva menção a uma sentença que seja a mais reta. Ora, a intuição plástica proporcionada por essa locução sugere que a sentença em questão não é avaliada em termos de uma solução intelectualmente construída para um dado problema, e sim em função de sua retidão - vale dizer, de sua conformidade a um padrão observável. Nesse sentido, o que se traduziu como sentença é, especificamente, uma fórmula: algo que se diz com um conteúdo necessariamente fixo, pois aponta para uma realidade objetiva, externa àquele que a profere. ${ }^{26}$

Veja-se, a esse respeito, a denominação do julgador nas línguas itálicas: de um lado, o iudex romano; de outro, o meddix osco, entre outras variações. Em ambos os termos se encontra a raiz *deik- para especificar a função do julgador. Tal função, em latim, assume caráter formular explícito por sua ligação a ius, que se refere a um modo de falar solene, pois relacionado a iurare, "jurar". Por sua vez, em osco, sobressai a ação de verificação de uma conformação segundo critérios objetivos, de acordo com o sentido da raiz *med-, anteriormente exposto.

No grego homérico, por sua vez, o juiz é dito $\delta \imath \kappa \alpha \sigma \pi$ ó̉os. Essa palavra tem

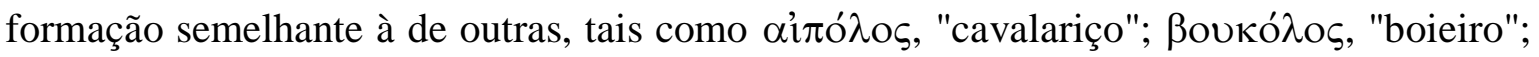

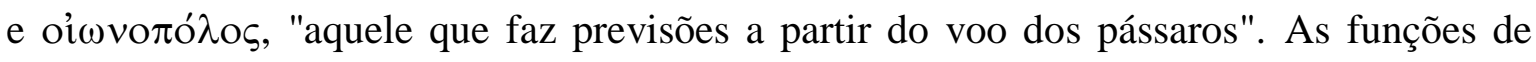
guarda designadas por esses termos valem para o $\delta 1 \kappa \alpha \sigma \pi \cos _{\mathrm{s}}$, aquele que vela pelas

$\overline{{ }^{26} \text { Benveniste, vol. 2, pp. 104-109. }}$ 
$\delta \imath \kappa \alpha \hat{\imath}$. A sentença equivale a uma fórmula indicativa dos limites, cuja guarda era atribuída ao julgador. ${ }^{27}$

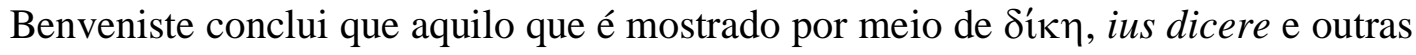
expressões de mesma raiz é aquilo que deve ser, uma prescrição ou uma determinação judicial. Contudo, acrescente-se tratar-se daquilo que deve ser em função do apontamento dos limites religiosos e naturais objetivos. Veja-se outro exemplo aduzido por Benveniste (Odisseia, 11, v. 218), no qual se lê que Odisseu, ao visitar o Hades, aí encontra sua mãe, a quem tenta abraçar, sem sucesso, sendo-lhe então esclarecido pela sombra materna que

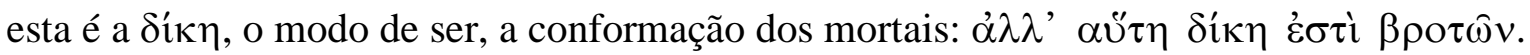

De qualquer maneira, há autores que se contrapõem à etimologia proposta por

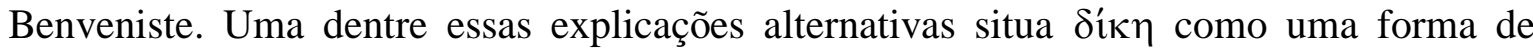
solução ritualística de disputas entre os gregos, em semelhança à ordália de seus primos indo-europeus, os povos germânicos. Essa interpretação se apoia na compreensão do

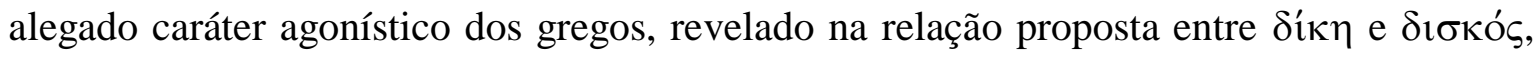
artefato cujo lançamento e queda mais aquém ou mais além do ponto previamente determinado definiria a solução do litígio. Jaeger, sem pôr em questão o espírito agonístico,

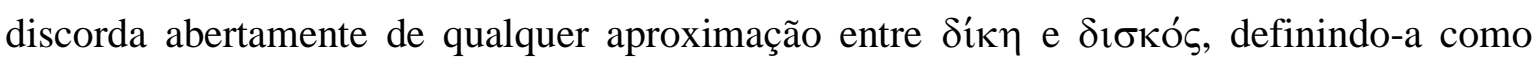
uma antiga palavra para a justiça, de natureza eminentemente processual. ${ }^{28}$

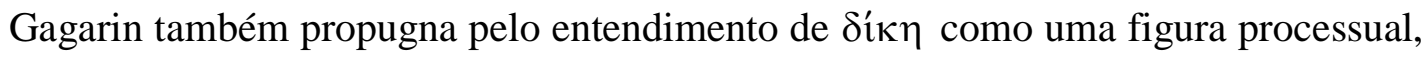
ao mesmo tempo em que afasta a sua correlação com métodos "irracionais" como o

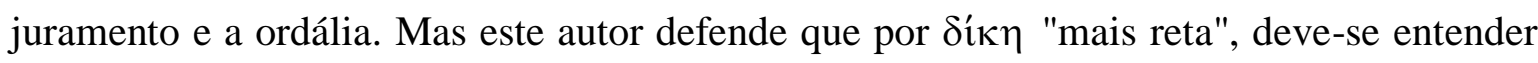
aquela que seja a mais aceitável para ambos os litigantes e para a comunidade, interessada na pacificação social. ${ }^{29}$ Como se vê, Gagarin insiste em defender que a origem da prática da solução de controvérsias entre os gregos está na ideia de acordo voluntário entre as

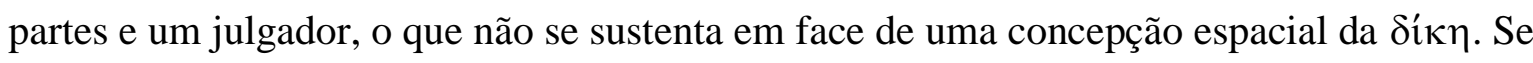
for verdade que a efetividade da sentença proferida está sujeita à sua aceitação por ambas as partes, não se vê razão para Hesíodo ter composto todo um poema para reclamar da falta de isenção dos juízes na querela entre o poeta e seu irmão. Bastaria a Hesíodo ter recusado

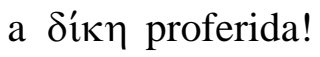

\footnotetext{
${ }^{27}$ BENVENISTE, vol. 2, p. 110.

${ }^{28}$ JAEGER, pp. 134-135; SOLON (2009), pp. 78-80.

${ }^{29}$ GAGARIN, pp. 28-32.
} 


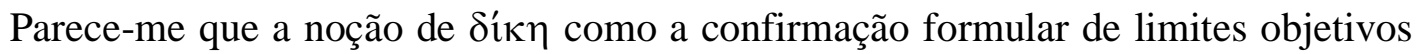
da realidade efetivamente encontra sua demonstração em Os trabalhos e os dias, poema que faz de Hesíodo o primeiro grande arauto de $\delta^{i ́ \kappa} \eta$. O suposto ideal agonístico de

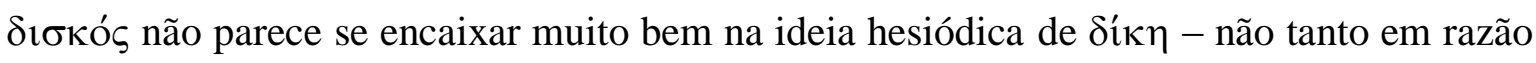
de se tratar o beócio de uma figura alheia à aristocracia, por sua notável redefinição da ideia de "̌pıs, "discórdia", em prol de uma ética do trabalho - quanto pelo fato de que Hesíodo não parece interessado no "jogo", na "disputa" em si, mas em efetivamente fazer valer o limite estabelecido. O ideal agonístico aristocrático não parece, portanto, ser da essência do problema em Hesíodo, sendo retomado, de forma reativa, com Teógnis e Píndaro.

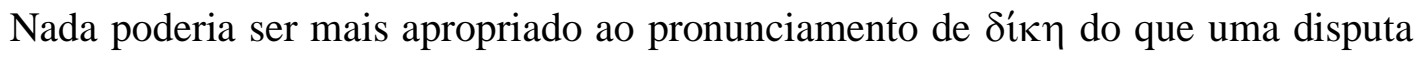
fundiária. O estudo filológico demonstra que o sentido objetivo de distribuição permaneceu

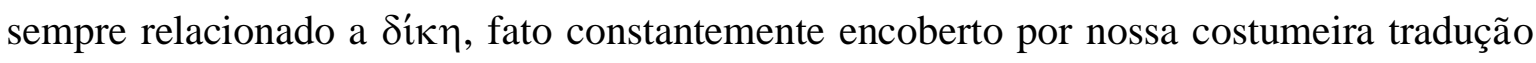

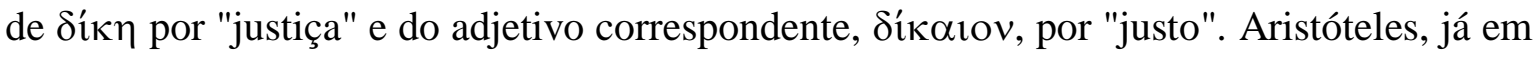
período muito mais recente da evolução da língua, reafirma o caráter objetivo e atributivo

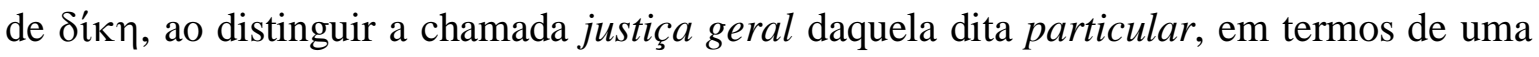

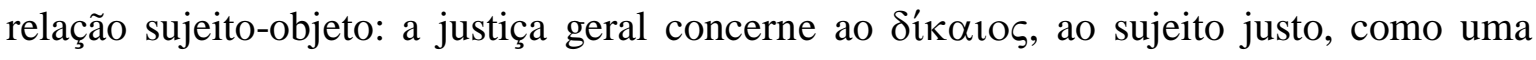
espécie de metavirtude que se reconhece em todo agente que sabe desempenhar suas diversas atividades de acordo com a medida equilibrada; ao passo que a justiça particular não se encontra no sujeito, como uma virtude, mas nas próprias coisas, de modo que competirá ao indivíduo reconhecer o justo, díkaıov. ${ }^{30}$

Trata-se a justiça particular aristotélica, portanto, do ofício de reconhecimento e

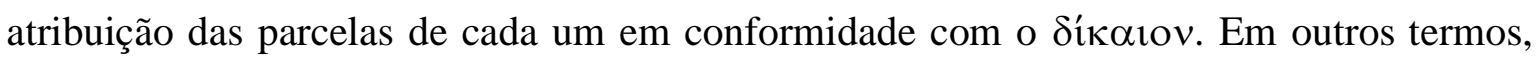
trata-se do ofício do juiz, dar a cada um o que é seu.

Com tal distinção, Aristóteles inaugura a província da ciência do Direito, como lembra Villey, pois separa o problema da justiça, como padrão de orientação das condutas humanas, do problema da aplicação do direcionamento justo na concretude. Com efeito, penso que a importância da distinção estabelecida pelo Estagirita é ainda muito maior, ao

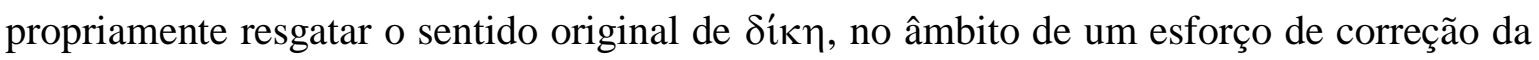
filosofia platônica.

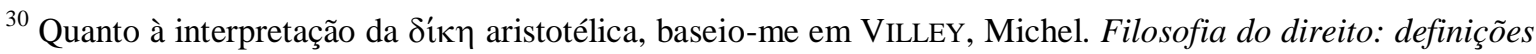
e fins do direito: os meios do direito. $2^{\mathrm{a}}$ ed. Martins Fontes: São Paulo. 2008, pp. 51-85.
} 
Digo correção porque o discurso do Sócrates de Platão promove a conjugação da justiça necessariamente com o desempenho de todas as demais virtudes, conforme o bem conhecido paradoxo da inseparabilidade das virtudes, o que melhor se coaduna com a noção de justiça geral, mas que dá azo a uma rigorosa ética de princípios que não se verifica cotidianamente no pensamento e no procedimento jurídico. Embora o conceito de justiça geral revele uma virtude eminentemente relacional, vinculada ao convívio social, não se confunde com o âmbito específico de atuação do Direito, afeito à justiça particular.

A justiça particular, já se apontou, diz respeito à distribuição dos lotes individuais por meio de uma declaração distributiva, o que conduz a casos limítrofes, nos quais se faz necessário maior esforço para a identificação de um lote cabível a cada um. Um desses casos é o das relações internacionais. Outro é o do ambiente familiar, no qual não haveria

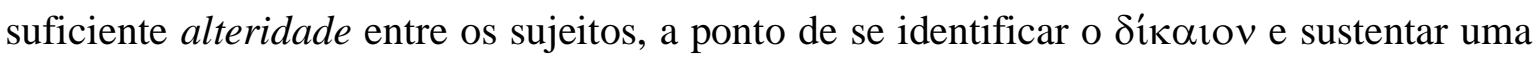
divisão do lote comum. Nisto se vê mais uma vez reafirmada a natureza interfamiliar primordial de $\delta \dot{\kappa} \kappa \eta$, essencialmente diversa, repise-se, do caráter familiar e divino inerente a $\theta \dot{\varepsilon} \mu 1 \varsigma$.

A respeito disso, há uma interessante passagem de Odisseia, 15, frisada por Benveniste, na qual Odisseu, recém-chegado a Ítaca após longa ausência, vestindo meros andrajos, é recebido por seu antigo porqueiro Eumeu, sem que este o reconheça. Em resposta ao agradecimento de Odisseu pela acolhida hospitaleira, Eumeu esclarece que a $\theta \dot{\varepsilon} \mu 1 \varsigma$ não permite destratar um hóspede, pois é de Zeus que provêm todos os hóspedes e todos os pobres. A mesma $\theta \dot{\varepsilon} \mu \iota \varsigma$ que rege a família determina que esta se abra ao estrangeiro. $^{31}$

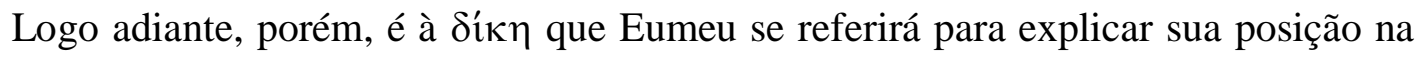
dinâmica do mundo exterior ao espaço da família, ao dizer que sua vida modesta se deve à

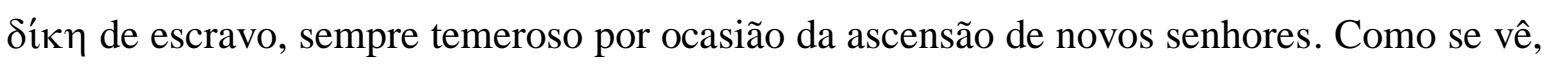

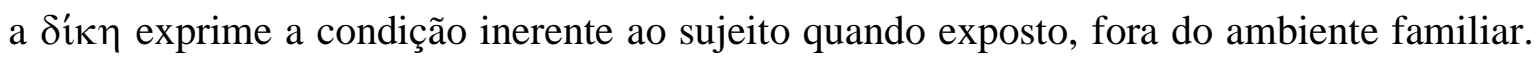
Na sociedade homérica, Eumeu não é marido, pai, fillho ou irmão, mas escravo, razão pela qual teme o domínio tirânico dos pretendentes.

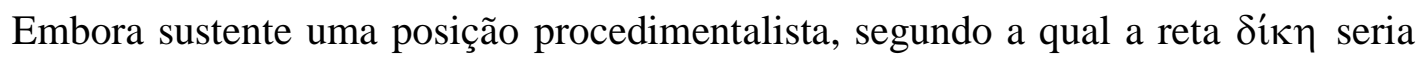
aquela que se equilibra adequadamente entre os reclamos de ambas as partes, de modo a

${ }^{31}$ Benveniste, vol. 2, p. 104. 
ser aceita pelos adversários por ser mutuamente satisfatória ou por força da persuasão ou da pressão social, nem mesmo Gagarin pode deixar de notar que a "straight" dikè may originally have been a boundary mark evenly dividing two pieces of property. Em favor da

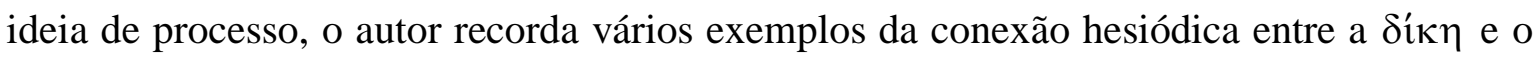

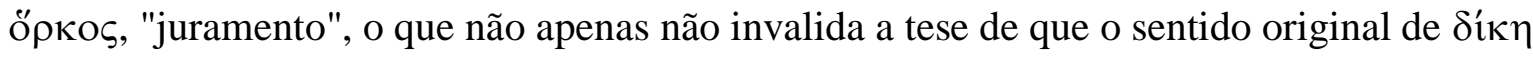
se liga ao espaço organizado como, na verdade, pode mesmo ajudar a corroborar tal posicionamento, uma vez que öpкos tem ele próprio natureza espacial, pois está

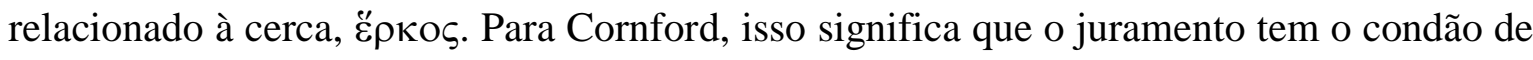

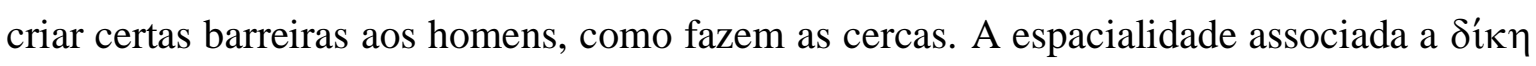
ganha plasticidade com a admoestação de Hesíodo a Perses, na qual o poeta lembra

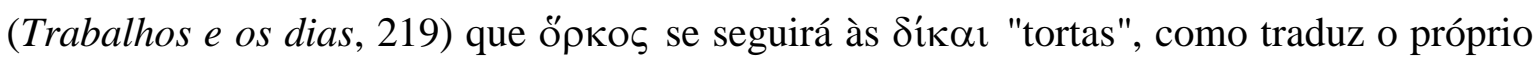
Gagarin. $^{32}$

O escopo deste capítulo foi demonstrar, a partir da análise dos radicais indoeuropeus, que o Direito antigo pode ser entendido como o estabelecimento e preservação de uma ordem cósmica objetiva e tangível, cujo conhecimento é acessível ao ser humano.

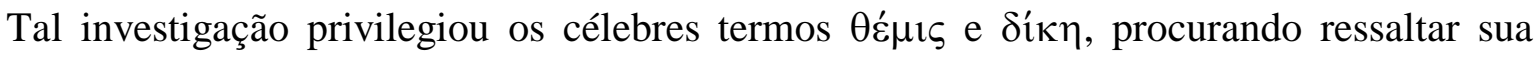
natureza cósmica, bem delimitados seus caracteres distintivos.

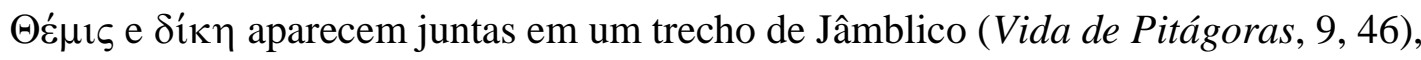
no qual se atribui a Pitágoras a correlação entre

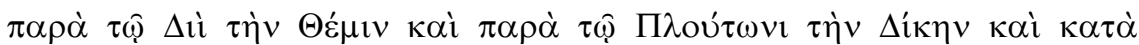

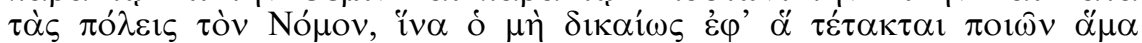

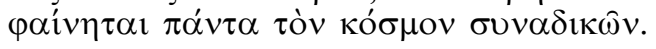

Themis no domínio de Zeus, díke no Hades e o nomos nas cidades, de modo que o que não cumpre retamente seu dever aparece como violador de todo o cosmo.
}

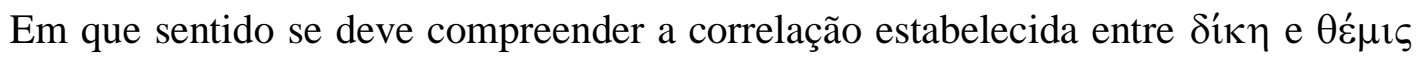

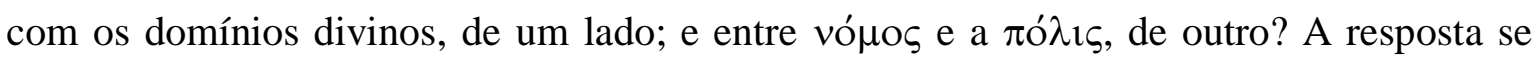
encontra na espacialidade do conceito de vópos, explorada no próximo capítulo, que conduzirá à discussão subsequente, acerca da ascensão da $\pi$ ó̉ı como o cosmo humano

\footnotetext{
${ }^{32}$ CORNFORD, pp. 24, 237; GAGARIN, pp. 23, 46-50.

${ }^{33}$ Apud CORNFORD, p. 54.
} 
conformado pela lei e por outras $\tau \dot{\varepsilon} \chi v \alpha \imath$ também igualmente relacionadas de maneira direta à ordenação do espaço. 


\title{
2. O arranjo cósmico da $\pi o ́ \lambda ı s$
}

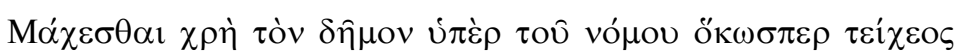

Lute o povo pela lei como pelos muros da cidade. Heráclito, fr. 44 DK.

O fragmento que encerra o capítulo anterior, atribuído a Pitágoras, traz novos elementos à nossa consideração, por conta do evidente paralelismo estabelecido entre

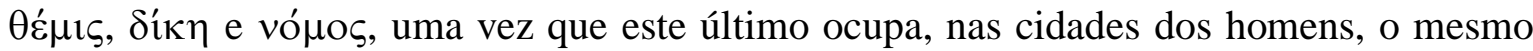
lugar que aquelas ocupam nos domínios de Zeus e do Hades, respectivamente.

Para Cornford ${ }^{34}$, tal correlação permite concluir que:

\begin{abstract}
Primitive beliefs about the nature of the world were sacred (religious or moral) beliefs, and the structure of the world was itself a moral or sacred order, because, in certain early phases of social development, the structure and behaviour of the world were held to be continuous with - a mere extension or projection of - the structure and behaviour of human society. The human group and the departments of Nature surrounding it were unified in one solid fabric of moirai - one comprehensive system of custom and taboo. The divisions of Nature were limited by moral boundaries, because they were actually the same as the divisions of society.
\end{abstract}

Em decorrência da discussão anterior, parece-me que Cornford se equivoca ao identificar a natureza da ordem total a partir das instituições humanas. Nesse particular, creio que se dê exatamente em sentido oposto, a saber, que as instituições humanas seriam percebidas como parte da ordem natural, e não a ordem natural como subordinada a uma moralidade projetada desde a sociedade.

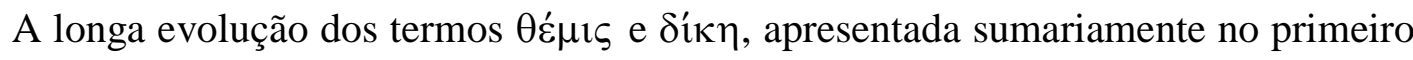
capítulo, aponta para a precedência de sentidos físico-espaciais desde os radicais linguísticos, de modo que apenas em momento posterior se atingiria uma noção moral do

${ }^{34}$ CORnFORD, p. 55. 
justo. Em nenhum momento se enuncia, no âmbito do sentido originário daquelas palavras, a defesa das determinações normativas sem que se leve em consideração a ordem objetiva das coisas, para além do humano. Ora, é a vida humana que é condicionada pelos limites que regem o todo, e não o contrário.

Com efeito, já em Homero se verifica uma concepção integrada dos planos divino e humano, cuja consequência necessariamente seria a construção de uma narrativa holística do mundo, pois o poeta concebe uma realidade em que há interações e repercussões recíprocas entre o movimento dos deuses e os feitos humanos, de maneira que a compreensão dos eventos demanda a consideração de sua totalidade cósmica e das diversas forças que aí operam. Tais forças encontram na soberania de Zeus um princípio de racionalização do universo. Em todo caso, a constatação da realidade descrita por Homero só pode se dar a partir de uma perspectiva onisciente, que explique todos os eventos da epopeia de maneira a desvelar o que está além do alcance parcial da visão humana. ${ }^{35}$

O entendimento correto da opinião de Pitágoras, em consonância com a tradição

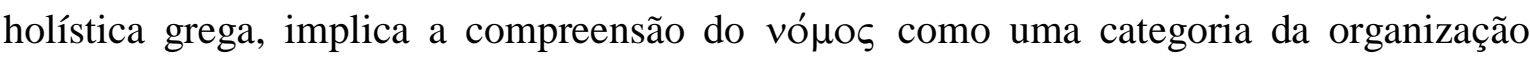

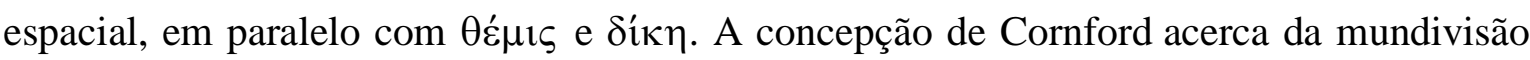
grega como uma compreensão moralizante da natureza, muito embora decorrente da percepção de um movimento histórico em sentido oposto àquela que orienta este trabalho, não deixa de ser uma afirmação do caráter espacial daquelas categorias.

De fato, dirá a respeito do vó o $_{\text {o }}$ professor de Cambridge ${ }^{36}$ :

We have dwelt upon these details in order to bring out the fact that behind the familiar sense of Nomos, 'custom,' 'use,' 'law,' lie traces of an older spatial significance - the notion of a range or province, within which defined powers may be legitimately exercised - what the Romans meant by a Provincia. This aspect of the idea has become obscured to us owing to the prevalence of the scientific notion of Law, which has become associated with causal sequences in time and has lost its old connection with space. For the understanding of the Greek word, it is necessary to grasp that Nomos does not suggest uniformity of temporal sequence, but exercise of power within spatial or departmental boundaries. We must think of Law as a dispensation or system of provinces, within which all the activities of a community are parcelled out and coordinated.

\footnotetext{
35 JAEGER, pp. 76-84.

${ }^{36}$ CORNFORD, p. 58.
} 
Os detalhes a que Cornford se refere são os desdobramentos semânticos de vópos, enquanto termo relacionado ao verbo vé $\mu \varepsilon \iota v$, que o autor traduz por "distribuir". Pode-se, por exemplo, distribuir as pastagens para a alimentação dos animais, bem como se tornar

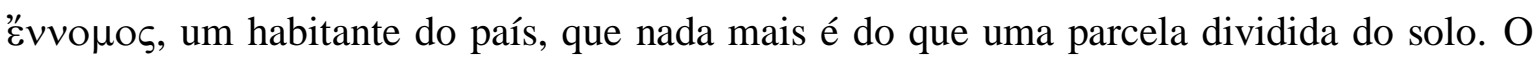
solo dividido e atribuído ao seu senhor também é referido pela antiga palavra $\eta \hat{\theta} \theta$ os. Esta

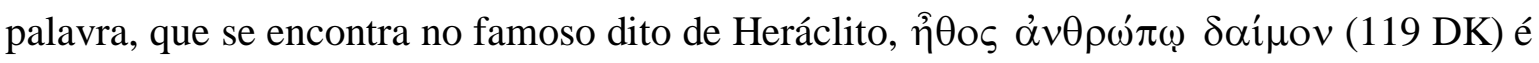
um termo geralmente traduzido como "caráter", mas que designa em sentido mais

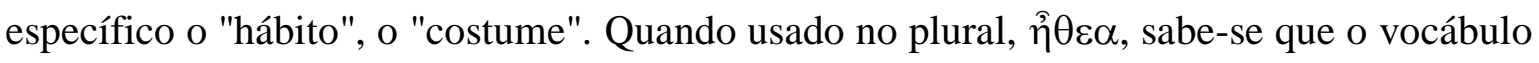
diz respeito não somente a "costumes", mas aos "lugares costumeiros", da mesma forma como estão relacionadas as palavras latinas "habitar" e "habitação". ${ }^{37}$

De fato, os diversos significados atribuídos pelo dicionarista ao verbete vé $\mu \varepsilon ı v$ oferecem em seu inusitado conjunto uma interessante gradação semântica, que quase poderia servir de sumário das relações entre os grupos humanos e dos processos históricos, pois a esse verbo corresponde: distribuir, dividir, determinar ao rebanho a parte do pastio que lhe toca, apascentar || alimentar || possuir, ocupar || dirigir, governar. ${ }^{38}$

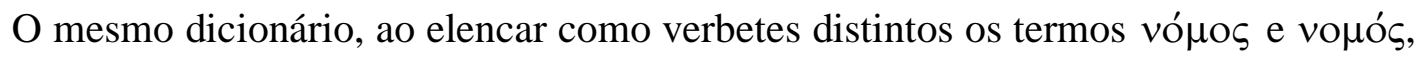
quase nos faz esquecer que o grego antigo não fazia uso de acentuação gráfica, apenas introduzida na escrita durante o período helenístico. Portanto, para a grafia clássica $\operatorname{NOMO} \Sigma$, tem-se vouós - parte || divisão de território, província, região || sítio para o pasto, alimento - e vó $\mathrm{oos}$ - uso, costume || opinião geral, máxima || lei || modo de música, canto. $^{39}$

Carl Schmitt está plenamente consciente de todas essas acepções atribuídas à palavra vó $\mu \mathrm{o}$, as quais são por ele suscitadas em sua obra Die Nomos der Erde. O entendimento do autor alemão sobre essa palavra merece atenção mais detida de nossa parte. $^{40}$

Para Schmitt, vó $\mu$ os não é, originariamente, um equivalente do termo alemão Gesetz ou de nosso conceito de lei, enquanto um qualificativo geral e abstrato para atos de

\footnotetext{
${ }^{37}$ ConnFord, pp. 29-30, 34, 64. Kahn, Charles H., A arte e o pensamento de Heráclito. S. ed. São Paulo: Paulus. 2009, pp. 408-410.

${ }^{38}$ PEREIRA, Isidro. Dicionário grego-português e português-grego. $8^{\mathrm{a}}$ ed. Apostolado da Imprensa: Braga.

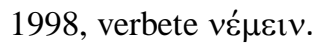

${ }^{39}$ Pereira I., verbetes vó $\mu$ os e vouóc.

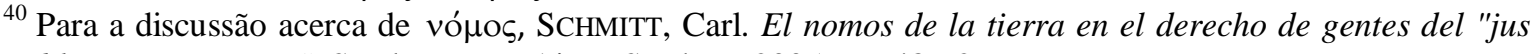
publicum europaeum". S. ed. Buenos Aires: Struhart. 2005, pp. 48-62.
} 
regulação ou de comando. O sentido primordial de vó $\mu$ os aponta para a primeira partição, divisão e distribuição do espaço. Nesse sentido espacial originário, vó $\mu$ os é a palavra mais adequada para expressar de maneira consciente o acontecimento fundamental do assentamento e ordenação comunitários.

Tal ato de ordenação adquire caráter crescentemente abstrato, em um movimento de anulação do sentido primitivo que remontaria aos sofistas, iniciado com uma série de distinções e antíteses conceituais, das quais a mais importante é aquela que se estabelece

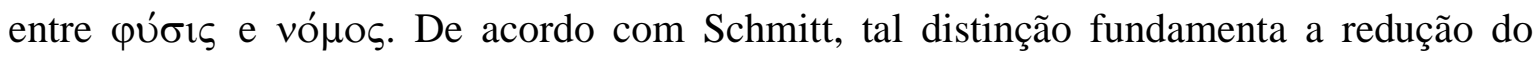
conteúdo do vó $\mu$ o̧ a um sollen esvaziado do sein primordial. Ao não mais se referir a um ato de tomada e distribuição do espaço, mas apenas a enunciados de implementação de disposições com a possibilidade de imposição coercitiva da obediência, vó $\mu \mathrm{o} s$ se incorpora à linguagem de uma época decadente, que já não consegue distinguir entre o direito fundamental de uma comunidade e meros regramentos decorrentes dos atos de governo.

Mesmo modernamente, a prevalência de uma compreensão deturpada do vó estaria relacionada à função hodierna da ideia de legalidade, que se resumiria a um padrão de funcionamento da burocracia estatal. A redução da legalidade a um parâmetro funcional de normalidade é patente no uso do conceito de "lei" no âmbito das ciências naturais. No primado do estado jurídico centralista, apenas a noção de legitimidade ofereceria um contraponto, já insuficiente, segundo Schmitt, à legalidade estéril, oposição à qual tampouco servem noções como uso, costume ou contrato, todas apresentadas pela dogmática a partir de relações dialéticas com a lei.

Ainda ao tempo do império dos Ptolomeus, já no período helenístico, as províncias recebiam a denominação de vópor. Entretanto, remonta à época clássica a ascensão das interpretações normativistas e positivistas dos sofistas. Essa ideia de vó $\mu$ o disposição ou preceito necessariamente viria a prevalecer em consequência da dissolução da $\pi$ ó $\imath_{\varsigma}$, encaminhando-se posteriormente para a instituição do culto do governante. Aqui, Schmitt acusa o positivismo do séc. 19 de ser um movimento de natureza contrária à do positivismo dos antigos, por ser aquele essencialmente ateu desde suas origens no niilismo por parte dos juristas, que teria sido motivado pelas pretensões de primazia científica das ciências naturais; pelas exigências técnicas da revolução industrial; e pelos reclamos de legitimidade dos revolucionários políticos da época. A lei se consolida como uma 
disposição dirigida à autoridade para a aplicação de sanções. Pior do que isso, a lei teria sido funcionalizada até o ponto de se converter a legalidade em um aparato a serviço do partido legislador, contra o partido excluído da legislação.

Indiscutivelmente, o vó $\mathrm{o}$ os original é muito mais interessante e rico em desdobramentos do que o quadro da modernidade apresentado por Schmitt. Tal sensação de descompasso é um efeito intencional de seu relato. O autor está ciente da relação de

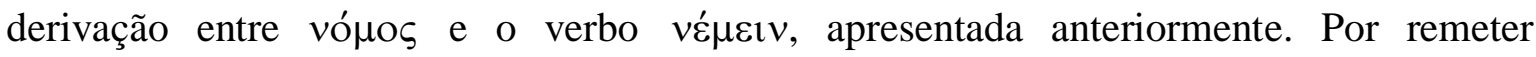
concomitantemente aos atos de dividir e de apascentar, trata-se da forma imediata por meio da qual se faz visível quanto ao espaço a ordenação política e social de um povo: a primeira medição e partição dos campos de pastoreio. Na tomada da terra se revela o vó $\mathrm{oos}$ por meio do qual determinado grupo se torna sedentário, vale dizer, se estabelece historicamente. O vómos pode ser considerado, sobretudo, a muralha, pois esta é traçada em conformidade com o assentamento sagrado. O vó $\mathrm{Oos}$ pode crescer e se multiplicar como a terra e a propriedade, pois de um único vó $\mu$ os divino se nutrem todos os vó $\mu$ or humanos. Schmitt assevera que "muralha" e "nutrição" não são noções mais anticientíficas do que a de "fonte" do direito, que Savigny ainda levava a sério, não obstante tenha já havia muito se tornado apenas uma metáfora.

Schmitt observa que, embora seu contexto de surgimento se relacione com a ordem espacial, é também significativo o fato de vó $\mu$ os se referir ainda à sucessão de tons, à ordem musical. Nesse ponto, devo observar que o qualificativo de vó $\mu$ o música não se exclui da realidade espacial. Ao contrário, os pitagóricos, que foram os descobridores das proporções matemáticas relativas à escala musical, compreenderam tais relações em termos espaciais. De acordo com o comentário esclarecedor de Copleston a

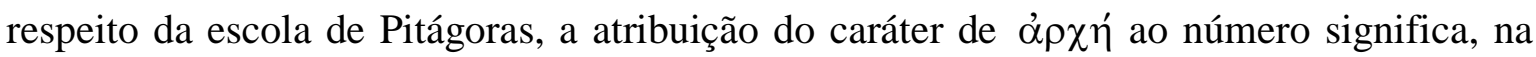
verdade, o entendimento de que o mundo se estrutura de conformidade a relações geométricas. O número pitagórico é uma posição geométrica, concepção formada com a

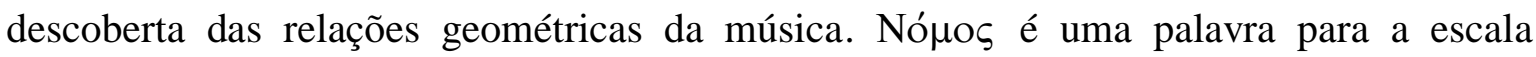
musical. Jaeger chama a atenção para a ilusória etimologia que quer ver no $\rho \cup ́ \theta \mu o \varsigma$ musical a derivação de $\rho \dot{\varepsilon ́} \omega$, do fluir desordenado. ${ }^{41}$

${ }^{41}$ COPLESTON, Frederick. Historia de la filosofía. $1^{\text {a }}$ ed. Barcelona: Ariel. 2007. Vol. 1, pp. 46-48; JAEGER, p. 161 . 
O ritmo está relacionado justamente com a imposição de limites à subjetividade, o que está na essência da poesia lírica dos tempos da formação da $\pi$ ó $\lambda \iota \varsigma$, sobretudo com Arquíloco. Esse gênero poético, ao conformar as emoções do $e u$ a um conjunto de limites, a uma forma, sem que a subjetividade vagueie solta, à maneira dos românticos, representará para o mundo da $\pi$ ó $\lambda ı \varsigma_{\varsigma}$ o que fora a epopeia para o mundo apolítico de Homero e Hesíodo: modelo e registro de um modo de vida e de uma mentalidade. ${ }^{42}$

Sobre Homero, especificamente, Schmitt afirma que a passagem inicial da Odisseia, na qual se diz que Odisseu muito navegou e conheceu o voós de diversas cidades e fortalezas, se trata na verdade de uma interpolação. Segundo o autor, a versão correta deveria trazer vó $\mu$ os em lugar de vóos. Sustenta sua opinião no fato de que o trecho em comento estabelece uma oposição em relação ao mar, o que faz sentido se o elemento contraposto é o vó $\mu$ os, uma vez que este tem clara ligação com a terra. Ademais, seria absurdo dizer que Odisseu tenha efetivamente conhecido os vóor de diversas fortalezas,

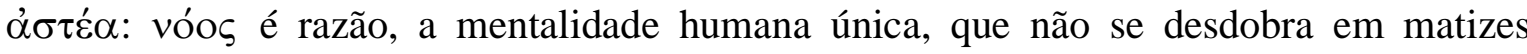
particulares em cada região, não está sujeita a relativismos culturais. Fortalezas não têm vóos; portanto, este não poderia ser conhecido pelo navegante em suas andanças, menos ainda com variações de cidade a cidade. A cerca, o fosso, o solo sagrado - esses são percebidos pelo viajante, são elementos que compõem o vó $\mu$ os, não o vóos. São ordenações divisoras e diferenciadoras do espaço, e não categorias psicológicas.

O sentido verdadeiro de vó $\mathrm{O}$ os para Schmitt implica constatar que todas as regulações ulteriores, escritas ou não, tomam sua força da medida interna de um ato primitivo construtivo de ordenação do espaço. Tudo o que a esse ato se segue é consequência, ampliação ou novas distribuições. Uma continuação sobre as mesas bases, ou então, modificações dissolutivas do ato constitutivo de ordenação do espaço representado pela tomada da terra, pela fundação da cidade e pela colonização. Atos inerentes à dinâmica de toda a história, de todos os tempos e povos.

A subjetividade conformada a limites é uma grande contribuição dos jônios para a cultura grega. A percepção de um plano cósmico integrado que sustenta expressões conscientes do eu e de seus limites explica a razão de o vó ser também a vontade de um só. Essa frase não deve ser mal compreendida, pois não se trata de uma justificação dos regimes tirânicos, mas da fundamentação da liderança

${ }^{42}$ JAEGER, pp. 150-164. 
esclarecida na legalidade do cosmo, que é unitária. Desamparada da lei, mergulhada na violência, a comunidade está entregue à úßpıs. O desastre público é evitado pelo comprometimento do povo com os seus próprios interesses vitais, de modo que lutar pela lei tem, assim como lutar pelas muralhas, o condão de evitar a pilhagem e o massacre. ${ }^{43}$

A lei e a partição do solo são um só evento, recebem um mesmo nome, vópos. Sentido único do $\lambda$ ó ${ }^{\circ}$, a lei deve ser o parâmetro em um regime político virtuoso. Não à toa, Aristóteles sustenta (Política, 1292a) a supremacia da lei como uma das notas diferenciadoras entre o governo da $\pi$ o $\lambda \imath \tau \varepsilon i \alpha$, dito "constitucional", e sua forma degenerada, a democracia. Nesta, a lei é deixada em segundo plano, pois o supremo poder está nas mãos das multidões, não raro manipuladas por dirigentes bajuladores. Soltas as amarras das leis, a atividade política segue descontrolada e se desorganiza.

Zarmanian resume precisamente a concepção do vó $\mu$ o $̧$ na obra de $\mathrm{Schmitt}^{44}$ :

\begin{abstract}
In The Nomos of the Earth Schmitt describes the emergence of any order, domestic or international, as a unitary process consisting of three fundamental actions: appropriating (nehmen), i.e. defining a determined space as the sphere of action of a particular legal-political principle; distributing (teilen), i.e. further organizing space by defining the terms of use and a system to securely determine the property (or any alternative system of resource distribution) of each area and resource within the common space; and exploiting (weiden), i.e. defining the rules of use and circulation of generated resources. Appropriation, distribution and exploitation are the earliest meanings of the Greek word 'nomos', which Schmitt therefore uses to convey the concrete profound co-implication of sovereignty and space and to extend it to the 'international' level.
\end{abstract}

Schmitt entende que a ordem concreta do vó $\mu$ os da Terra não é um arranjo totalmente artificial, baseado em elementos puramente normativos, e tampouco uma ordem natural, no sentido de ser um produto necessário das condições materiais. Tal ordem natural é o que Schmitt chama de kosmos. ${ }^{45}$ Kó $\sigma \mu$ os, com seu correspondente latino, mundus, é o nome por excelência da ordem espacial. Como a noção de ordenamento espacial tem sido enfocada, até este ponto, como o substrato etimológico e semântico das ideias jurídicas dos povos indo-europeus, é chegado o momento de analisar de maneira mais detida este que é o segundo termo equívoco do fragmento de Pitágoras.

\footnotetext{
${ }^{43}$ KAHN (2009), pp. 274-277.

44 ZARMAnIAN, Thalin. Ordnung und Ortung/order and localization. In: LEGG, Stephen (ed.). Spatiality, sovereignty and Carl Schmitt: geographies of the nomos. ${ }^{\text {st }}$. ed. London: Routledge. 2011, p. 292.

${ }^{45}$ ZARMANIAN, p. 295.
} 


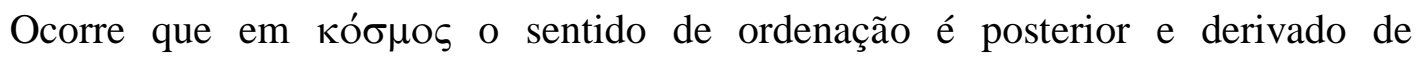
ampliações semânticas sofridas pelo uso da palavra, que surge de forma muito mais singela do que a carga de significação posteriormente assumida pelo termo poderia denotar. Em

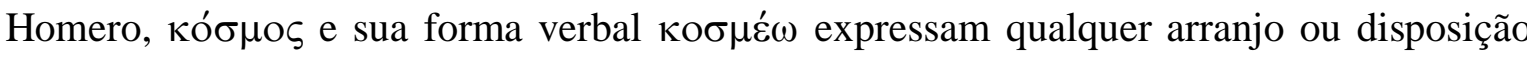
apropriada das partes de um todo, em função de sua forma e efetividade, e não segundo algum critério de adequação moral ou social. ${ }^{46}$

Exemplos homéricos colacionados por Charles H. Kahn e Maria Helena da Rocha

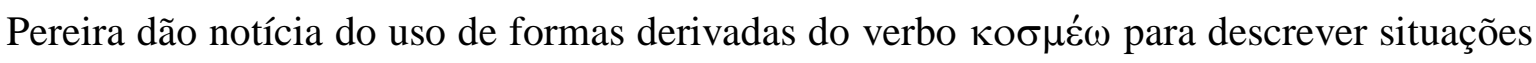
tais como a da tropa que se mantém em formação durante a marcha (tal qualificação de $\kappa o ́ \sigma \mu \mathrm{s}$ aplicada à disciplina de um exército também é atestada em Tucídides), do ajuste adequado da flecha ao arco, da preparação de uma refeição ou do ato de limpeza do recinto

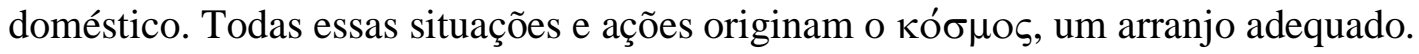

Este sentido geral de alguma forma perdura ainda muito tempo depois da composição dos poemas homéricos. Veja-se Heródoto, que ao descrever a ponte sobre o Helesponto que propiciaria o acesso dos persas à Grécia, informa que as peças de madeira

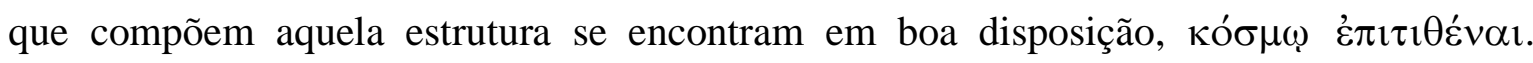
Interessante observar que o verbo utilizado, $\dot{\varepsilon} \pi \imath \imath \theta \varepsilon \dot{\varepsilon} \mu$, é uma forma composta pela

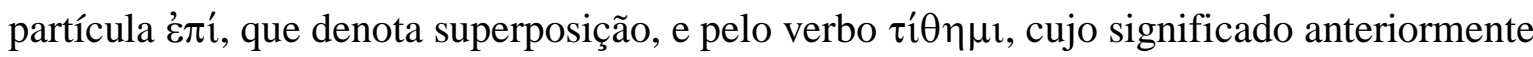

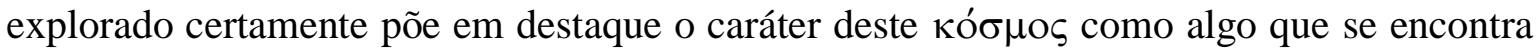
organizado de maneira adequada e eficiente.

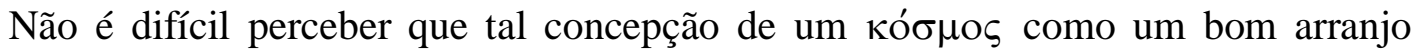
físico não tardaria a se aplicar também como um juízo de valoração estética desvinculado do aspecto da eficiência da disposição segundo uma finalidade qualquer, assumindo, portanto, uma dimensão que se pode dizer propriamente cosmética. Assim passa-se a

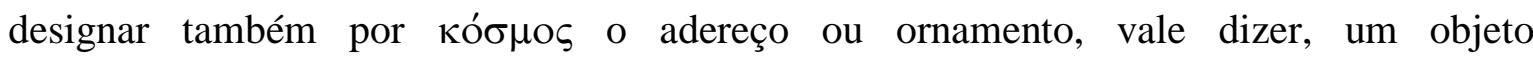
artisticamente trabalhado com a finalidade de servir de adorno, dotado da marca de preciosidade. Em Homero, vê-se que ao saquear Troia os aqueus arrebataram incontáveis кó $\mu_{\mu o}$ do palácio da cidade.

Neste sentido, mesmo a poesia pode ser definida como um trabalho elaborado de adorno, definida respectivamente por Sólon e por Orfeu como algo belamente dito ou

\footnotetext{
${ }^{46}$ Sobre a evolução do termo, KAHN, Charles H. Anaximander and the origins of Greek cosmology, pp. 219230; PEREIRA, Maria Helena da Rocha. Estudos de história da cultura clássica, vol. 1, pp. 236-238.
} 


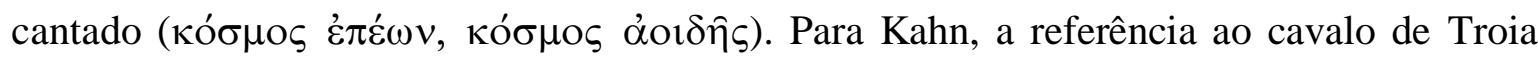
como i $\pi \pi \mathrm{o} \varsigma$ кó $\sigma \mu \mathrm{o}$ deve ser entendida neste sentido de obra artística elaborada. No entanto, penso que neste passo o cavalo de madeira também pode ser compreendido como

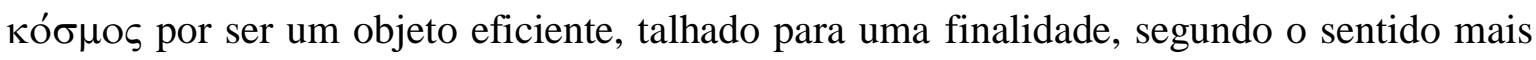
primitivo.

Aplicada de forma gradativamente crescente a grupos humanos, embora sem que se

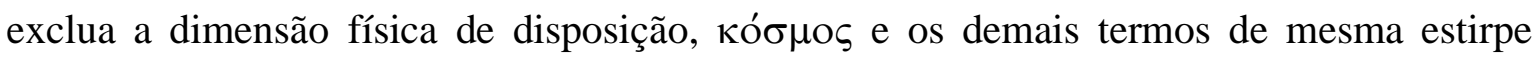
assumem explicitamente uma conotação de arranjo social. Ainda em Homero, o mesmo $\lambda \alpha$ ó $\varsigma$ que se dispõe de maneira disciplinada para a guerra também assume forma de um $\kappa o ́ \sigma \mu o \zeta$ ao se dispor em círculo em torno de Telêmaco, para deliberar em assembleia.

Do mesmo modo, ao se dizer de determinada ilha, cujo povo se divide em três

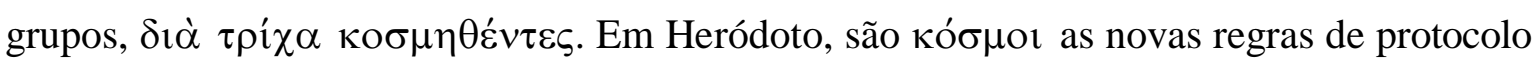

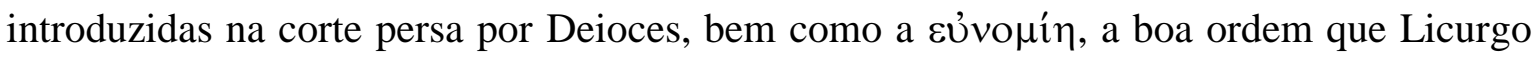
aprendeu do Oráculo de Delfos e implantou em Esparta.

Importante exemplo não literário da importância social desta palavra no âmbito social é extraído do texto das leis da cidade cretense de Górtina, que denomina кó magistrados de amplos poderes, que elaboravam as leis submetidas à votação pela assembleia, lideravam as tropas em guerra, presidiam os deveres religiosos e arbitravam

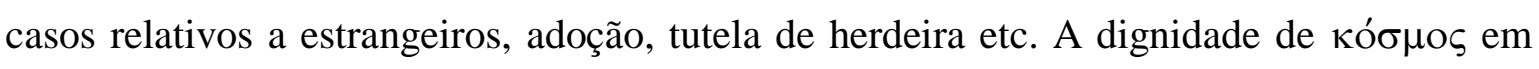
Górtina não permitia a recondução, a fim de que seus detentores não se tornassem descurados ou corruptos, exatamente como se dera com o juiz que presidiu a querela entre Hesíodo e Perses ${ }^{47}$.

Já se vislumbra aqui o sentido daquilo que chamaríamos aristotelicamente de

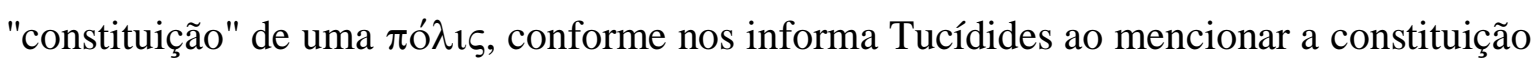

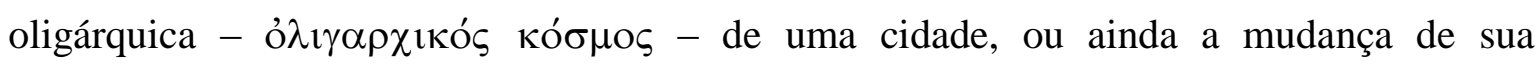

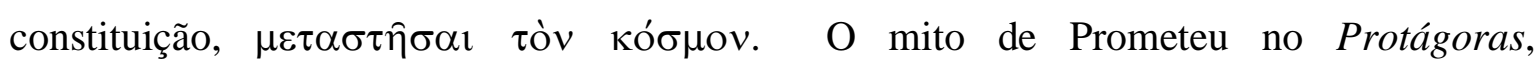

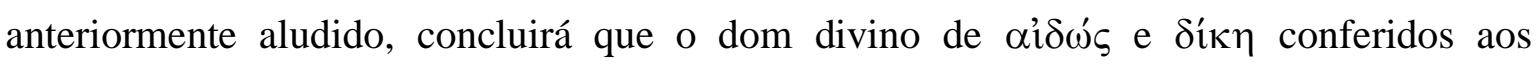

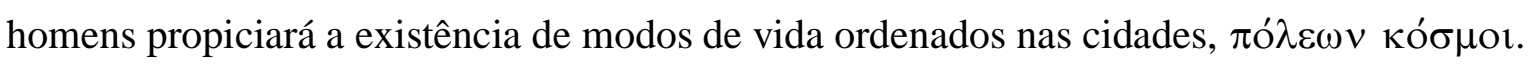

Há ainda outra frase de Heródoto que permitirá que se avance na análise da

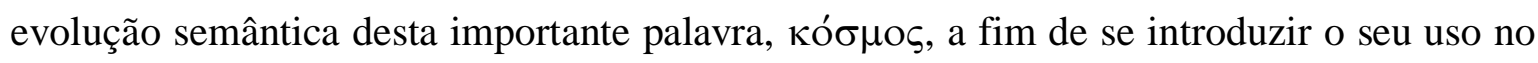

${ }^{47}$ Gagarin, pp. 93-94; ArnaOUtOGlou, Ilias. Leis da Grécia antiga, $1^{\text {a }}$ ed. São Paulo: Odysseus. 2003, p. 172. 
pensamento filosófico desenvolvido na Jônia do século VI a.C., ao mesmo tempo em que a conectará com o sentido primitivo de vó $\mu$ os.

Heródoto (História, 2.52.1) oferece uma etimologia da palavra $\theta \varepsilon o ́ c$, que, embora possivelmente não seja a mais acertada, é de interesse para a argumentação presente por conectar $\theta \varepsilon$ ó $\varsigma$ com o ato de dominação fundado na criação expresso pela raiz já discutida de $\theta \varepsilon \dot{\mu} \mu 1 \varsigma, * d h \hat{e}-$, ao dizer que os deuses ( $\theta \varepsilon o i ́)$ são assim denominados porque "tendo disposto $(\theta \dot{\varepsilon} \nu \tau \varepsilon \zeta)$ todas as coisas em ordem, eles também tiveram a posse de todos os

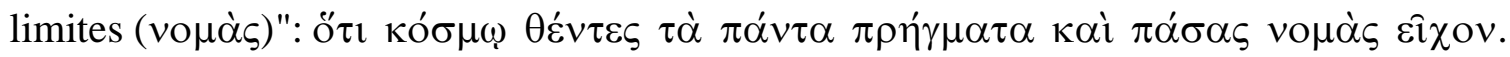

Apenas o conhecimento do radical ligado a $\theta \dot{\varepsilon} \mu \iota \varsigma$ e de seu significado, conforme aclarados por Benveniste, permite enxergar sua conexão com a frase de Heródoto. Kahn,

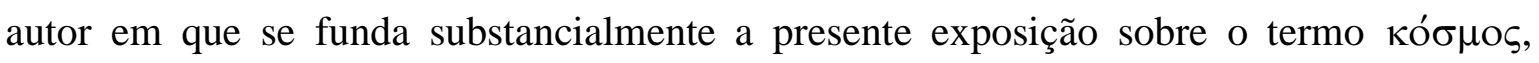
silencia sobre tal relação, que, bem se diga, não se comunica com o seu objetivo pontual ao

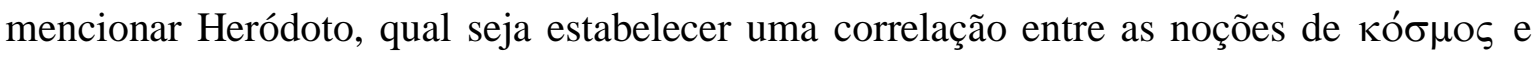
$\delta \alpha \sigma \mu o ́ s$.

O tema do $\delta \alpha \sigma \mu o ́ \varsigma$ diz respeito à ideia de uma pluralidade de deuses que partilham entre si as diversas regiões do universo. Sua primeira expressão literária entre os gregos se dá com a Teogonia de Hesíodo. Contudo, este poeta não menciona a palavra кó $\sigma \mu \mathrm{o}$ ao descrever o mesmo processo narrado por Heródoto. Hesíodo diz (Teogonia, vv. 73 e ss.) que Zeus "dispôs de maneira apropriada [trata-se de outra raiz] as porções para os imortais,

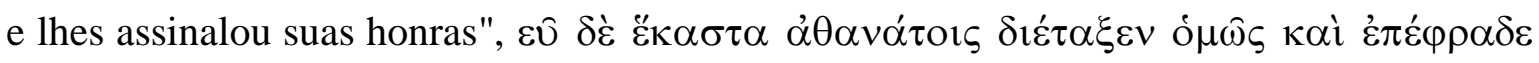

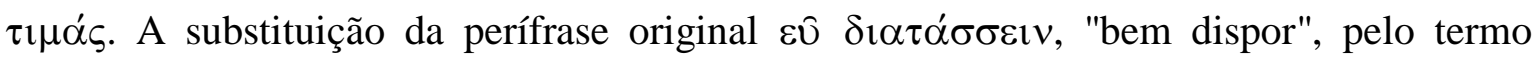

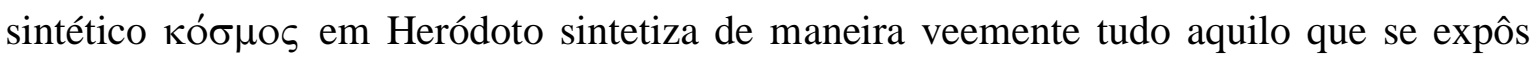
quanto ao significado desta palavra até o momento.

Há que se asseverar, contudo, que Kahn se mantém em um nível superficial de

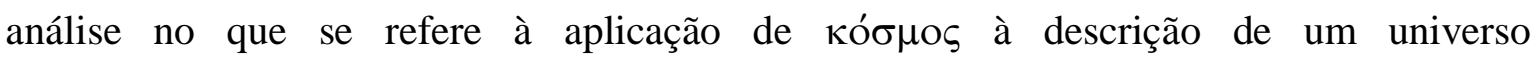
harmoniosamente engendrado. $\mathrm{O}$ autor sustenta que o uso desse termo é introduzido na filosofia pré-socrática de maneira semelhante ao ocorrido em Heródoto, isto é, como uma reinterpretação consciente do tema hesiódico do $\delta \alpha \sigma \mu$ ó $\zeta$, de modo que a repartição outrora atribuída às divindades teria sofrido um processo de racionalização, por meio do qual as figuras míticas seriam substituídas pelas forças da natureza, que têm suas funções e limites bem definidos pelo arranjo cósmico. Ao mesmo tempo, o sentido intermediário de arranjo social teria continuado no uso corrente, o que teria justificado a adoção analógica 
consciente de uma terminologia moral e política na cosmologia grega, por meio de

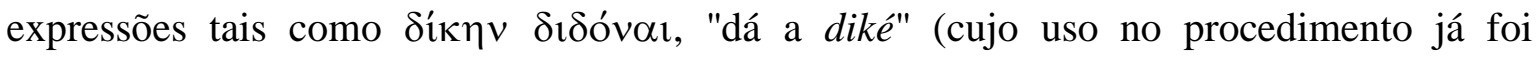
mencionado), de Anaximandro; ou o vó $\mu$ os de Heráclito.

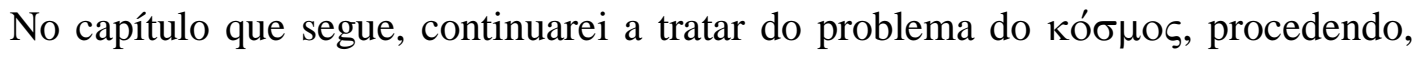
contudo, ao esclarecimento sobre a nova expressão física da igualdade jurídica, que propiciou diretamente o surgimento da cosmologia milésia: a arquitetura da $\pi$ ó $\lambda$ เs.

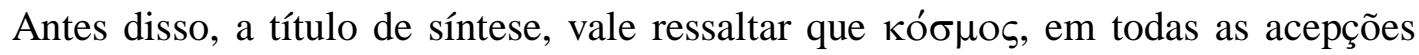
verificadas em grego, encontra no termo romano mundus o seu equivalente. A esse respeito, os exemplos colacionados da literatura pelo Dicionário latino-português de Saraiva, que traz quatro entradas diferentes para referido vocábulo. Excluída a quarta e última, referente ao nome próprio masculino Mundus, desprovida de importância para os propósitos atuais, são as seguintes as acepções do termo, que ora se apresenta em forma adjetiva, ora substantiva:

\footnotetext{
1 Mūndŭs, $\breve{a}$, ŭm, adj. HOR. COLUM. Limpo. Homo mundus. HIER. Homem são (limpo de lepra). § CIC. LIV. Elegante, apurado, pichoso (com respeito ás pessôas e ás coisas). § HIER. Limpo, purificado, puro. Mundus sum a sanguine. HIER. Não estou manchado de sangue. § LAMPR. Que é da primeira qualidade (o pão). § ENN. Provido, fornecido de. (...).
}

2 Mūndŭs, ī, s. ap. m. CIC. VIRG. FEST. O ceu, a abobada celeste, o firmamento. $\S$ CIC. OV. Mundo, universo, a creação. $\S$ HOR. STAT. Globo terrestre, o mundo, a terra, as nações. In mundo. ENN. PLAUT. N'este mundo, sobre a terra; em publico, claramente, abertamente, á mão. $\S$ ALCIM. PROSP. O mundo; o seculo. $\S$ LUC. O imperio Romano. § MACR. FEST. Mundo subterraneo, os infernos. §SEN. O mundo considerado como Deus. $\S$ Plur. PLIN.

3 Mūndŭs, ī, s. ap. m. FEST. APUL. Objectos de toucador, adornos, atavios, enfeites (das mulheres). Mundus mulieoris. LIV. PHAED. A m. signif. \& ULP. Enxoval. § Fig. APUL. Utensilios, instrumentos. Mundus Cereris. APUL. Cabazes sagrados de Ceres (com todos os objectos que conteem).

Observa-se, em resumo, que a raiz latina deu origem aos seguintes significados principais: 1) aquilo que é imaculado, dotado de pureza; 2) o universo e o conjunto de suas partes; e 3) adorno, enfeite. Interessante notar como até mesmo a noção de sensação de pureza se mantém presente entre nós, ao menos pela via negativa, conforme atestam as formas portuguesas imundo, imundície.

Segundo certas fontes, mundus provém de movere, o que justificaria ser o termo usado para designar o firmamento, com seu movimento peculiar. Descrito como uma 
lareira situada em uma cavidade no solo, o mundus deve ter sido, no âmbito de um esquema hierogâmico, a contraparte simbólica feminina do arado usado para traçar os limites da cidade fundada ${ }^{48}$.

O mundus mulieoris a que se refere a terceira acepção era uma espécie de bolsa feminina, a cista, em que se carregava cosméticos e demais produtos de higiene e adorno. Seu nome está associado ao verbo mundere, "limpar", "arrumar". Na mesma entrada há a referência a Ceres. Embora muito se discuta sobre qual seria o aspecto da construção a que os romanos chamavam mundus - se um simples fosso ou uma câmara subterrânea abobadada - é certo que em sua cavidade eram anualmente depositados, como primícias da terra, os cereais, dedicados à deusa que lhes dá nome. Como assinala Fustel de Coulanges, o mundus era também receptáculo dos torrões de terra trazidos pelos habitantes da nova cidade, que deste modo asseguravam a continuidade de sua ligação ao solo de sua linhagem familiar. Também eram jogados ali os torrões da terra que circundava a cidade, a fim de ligar a esta a produção agrícola. Símbolo de fertilidade e morte, considera-se atualmente que o nome do mundus possa provir da divindade infernal etrusca, $\mu \nu v \theta v$ ou $\mu \nu v \theta v \chi$. Seja qual for a origem morfológica da palavra, sua conexão semântica com

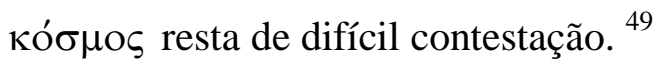

\footnotetext{
${ }^{48}$ Sobre a simbologia da lareira, veja-se o exposto no próximo capítulo; para o uso do arado, o capítulo final, sobre os ritos romanos.

${ }^{49}$ RYKWERT, Joseph. A ideia de cidade. S. ed. São Paulo: Perspectiva. 2006, pp. 134-145.
} 


\section{Três relatos cósmicos: cosmologia, arquitetura e legislação}

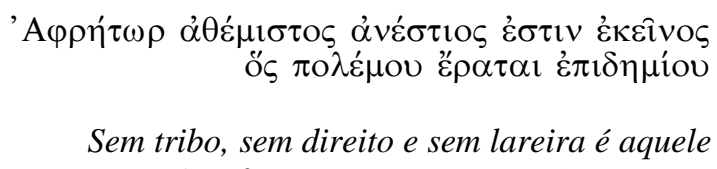
Que faz a guerra entre o próprio povo.

Ilíada, 9, 63 e s.

Vimos acompanhando o desenvolvimento das concepções relativas a certos termos

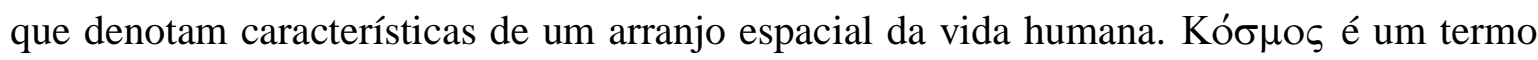
muito importante, pois, como expressão sucinta da noção de ordem ou disposição, da harmonia física engendrada, adquire gradativamente o vulto de um problema filosófico, ao se vislumbrar no próprio universo a expressão maior de um arranjo harmonioso. Contudo, conforme visto, antes de ter esse uso disseminado na literatura filosófica, o primeiro grande alargamento do campo semântico de кó $\sigma \mu$ os se deu com o crescente uso do termo para designar a organização da $\pi$ ó $\lambda ı$ c . Ao contrário do uso em suas acepções estéticas e

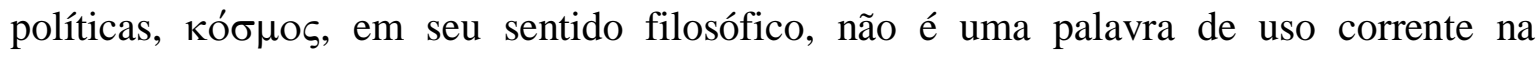
linguagem popular do século IV a. C., permanecendo aparentemente restrita aos meios acostumados à especulação cosmológica. ${ }^{50}$

Natural, portanto, que se busque em medida variável estabelecer uma correlação entre as origens do problema cosmológico da filosofia e as ocorrências políticas do período. No entanto, as explicações oferecidas são insuficientes, pois os historiadores se contentam em demonstrar os processos políticos que teriam propiciado o advento do pensamento filosófico, o que lhes permite identificar analogias entre a organização da sociedade e o modelo cosmológico proposto pelos filósofos. Feito isso, os analistas concluem que a imagem do cosmo descrita pelos primeiros filósofos é um reflexo da nova organização político-jurídica de suas sociedades, cuja dinâmica é metaforicamente transplantada da cidade para a cosmologia pelos pensadores, para explicar o universo.

\footnotetext{
${ }^{50}$ KAHN, Charles H.. Anaximander and the origins of Greek cosmology. s. ed. Indianapolis: Hackett. 1994, pp. 219-222.
} 
Equívoco completo.

O sentido em que se operou a mudança da explicação cosmológica é invertido pelas reconstruções modernas da história da filosofia. A explicação do cosmo fornecida pelos primeiros filósofos, contrariamente aos relatos míticos, estabelece um cenário de forças impessoais, de modo que não se deve interpretar seu surgimento como uma tentativa de enquadrar os fenômenos do universo nos parâmetros da sociedade humana. Ao contrário, a racionalidade descoberta no cosmo pela filosofia milésia é usada politicamente para fundamentar uma nova ordem na $\pi$ ó $\lambda \iota \varsigma$, em ataque à fonte mítica de legitimidade do regime anterior.

Toda a comunicação terminológica e estilística que se verifica entre a prosa filosófica e político-legal decorre da unidade de fundamentação em um mesmo cosmo, e não em um uso metafórico de categorias sociais para explicar o universo. A vigência de uma ordem espacial impessoal no universo é descoberta pelos filósofos com apoio em conhecimentos tecnológicos orientais, os quais continham em seu bojo um instrumental de racionalidade que informaria o desenvolvimento da forma primordial do discurso em prosa sobre a $\tau \dot{\varepsilon} \chi \nu \eta$ na Jônia, os textos sobre arquitetura, cujos métodos permitiriam a desmistificação da natureza que viria a inaugurar a filosofia e se somar à legislação escrita como fatores de enquadramento das práticas políticas em um padrão racional de estabilidade.

É o que passo a desenvolver.

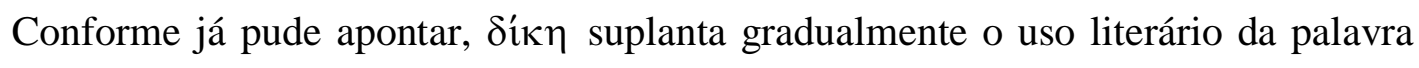
mais antiga, $\theta \dot{\varepsilon} \mu \imath \varsigma$, enquanto paradigma do direito. Isto provavelmente se dá em decorrência do caráter indicativo dos limites estabelecidos entre uma pluralidade de famílias inerente a $\delta_{i ́ \kappa}$, em contraposição ao predomínio patriarcal no seio de uma única

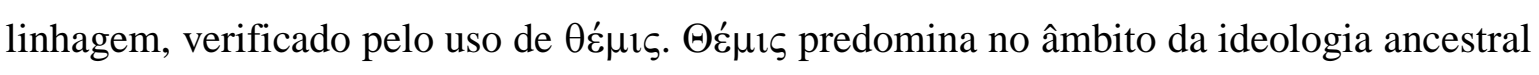
da civilização micênica, de acordo com o testemunho do ideário de formação e comando da nobreza guerreira colhido da Ilíada.

A superveniência da invasão dórica representou a desarticulação da civilização palaciana de Micenas, o que levou a novas formas de organização social, vez que a desagregação das unidades políticas até então existentes, as migrações forçadas e o forte declínio populacional acarretaram a formação de clãs autônomos, os ‘ै $\theta$ vor, distribuídos de 
maneira esparsa pelo território e sob o comando de lideranças familiares próprias. Com a gradual reorganização da vida comunitária, tais líderes passaram a constituir a realeza de cada região. $^{51}$

Juntamente com a reorganização social sobreveio a recuperação demográfica, o que certamente contribuiu para tornar mais complexas as relações sociais até então baseadas na dinâmica tribal, eventualmente ocasionando a contestação da autoridade dos antigos senhores dos $\check{\theta} \theta v o 1$, no cenário das $\pi$ ó $\lambda \varepsilon 1 \varsigma$ em formação.

É o processo de falência da dominação dos ع̋ $\theta$ vor que Aristóteles aparenta ter em mente, ao tratar da monarquia heroica em sua tipologia das diversas formas do regime monárquico (Política, 1285b). Há que se notar que Aristóteles enumera entre as ações notáveis dos monarcas a promoção da divisão da terra ao lado de fomentarem as artes $(\tau \dot{\varepsilon} \chi \vee \alpha \varsigma)$, conduzirem a guerra e os sacrifícios religiosos, bem como presidirem os julgamentos, que conduziam com o cetro. Algo melancólico, Aristóteles é sucinto ao mencionar que esses governantes de tempos antigos gradativamente perderam o poder, em parte devido à usurpação das multidões.

A pressão demográfica, para além de propiciar semelhante crise de legitimidade no seio da autoridade aristocrática, ocasionou o problema da disputa por terras cultiváveis. Ao longo da evolução da $\pi$ ó $\lambda \iota \varsigma$, mesmo em sua etapa clássica, continuou a posse da terra a ser um notável foco de conflito ao mesmo tempo em que seguia como um dos fatores mais intimamente relacionados à caracterização da cidadania, dando azo a diversas normas relativas à propriedade fundiária. ${ }^{52}$

O esforço aristocrático para a manutenção do poder se valeu de diversos instrumentos e inovações, que, no entanto, findaram por catalisar as contradições de sua dominação, favorecendo sua decadência. Dentre tais inovações, a primeira a ocorrer é a formação dos primeiros corpos regulares de hoplitas, grupos de infantaria pesada constituídos pela gente comum do povo, sob o comando das aristocracias locais.

No entanto, a constituição das falanges de hoplitas resultou ideologicamente no

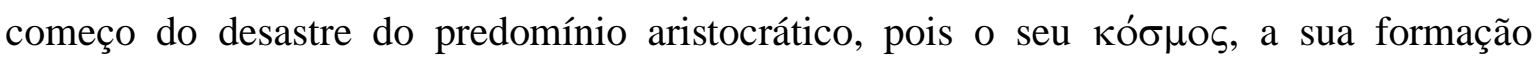
combativa, implicava a interdependência dos soldados, que marchavam alinhados para que

\footnotetext{
${ }^{51}$ HAHN, Robert. Anaximander and the architects: the contributions of Egyptian and Greek architectural technologies to the origins of Greek philosophy. $1^{\text {st }}$. ed. New York: State University of New York. 2001, pp. 66-67; 226-229.

${ }^{52}$ ARNAOUTOGLOU, pp. 119, 123-127.
} 
pudessem se proteger mutuamente com os pesados escudos. Devido à necessidade de manutenção da linha defensiva, a função de hoplita desencorajava em definitivo qualquer intento de realização de grandes atos heroicos individuais, o que ia de encontro à tradição

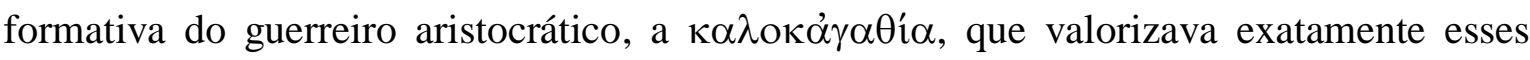
grandes feitos relembrados por meio da narrativa dos combates individuais na Ilíada, ditos aristeias. Cabe lembrar que este ideário aristocrático do guerreiro já fora rompido pela própria criação das falanges de hoplitas, já que isso significou o fim do privilégio aristocrático do cultivo das artes militares. ${ }^{53}$

Mais do que simplesmente contrariar os preceitos de um modo de vida tradicional, este adestramento militar com características de igualdade e de renúncia aos feitos de destaque favoreceu o surgimento do ideal da isonomia política. Durante todo o período de

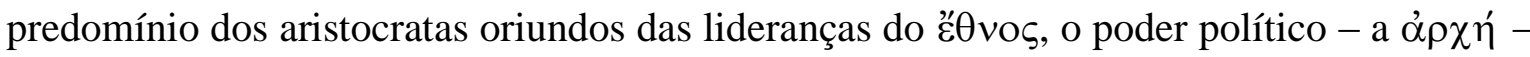
era compartilhada de forma relativamente igualitária entre aqueles nobres que se ocupavam das práticas militares, com a exclusão total das demais camadas da população. Por tais razões, o corpo de hoplitas, que primordialmente se tratava de um instrumento de

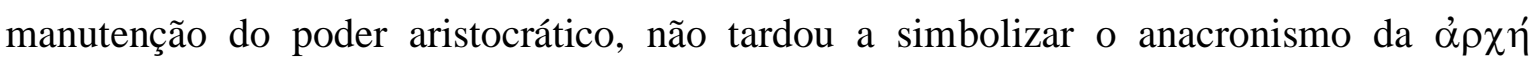
aristocrática, até o ponto de efetivamente se voltar contra os seus antigos senhores, incitado pelo questionamento do poder social fundado no $\varepsilon^{\prime} \theta v o \varsigma$, provocando sua derrocada.

Outro artifício para a manutenção do poder político pelas classes aristocráticas dominantes trata-se da instituição da tirania. Embora os próprios gregos tenham geralmente caracterizado a ascensão de regimes tirânicos como um movimento popular de usurpação do poder aristocrático, deve se levar em conta que, especialmente no caso da Jônia, a instauração de diversos regimes tirânicos sucessivos e de curta duração se deu sob a forma de golpes por parte de indivíduos oriundos das próprias classes aristocráticas, com a

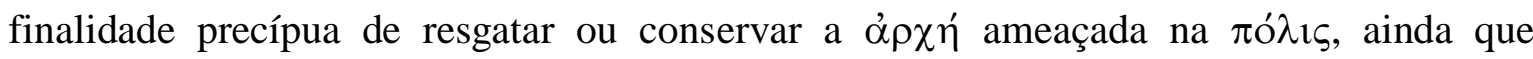
eventualmente com o apoio inicial das massas. Entreato na transição do domínio aristocrático para a instauração da isonomia, a tirania sucumbiu na generalidade das $\pi$ ó $\lambda \varepsilon 1 \varsigma$ jônicas devido ao personalismo do tirano, que levou à eclosão de reações populares, geralmente apoiadas na predominância numérica e na força dos hoplitas, conduzindo à efetiva reformulação das bases do domínio político. ${ }^{54}$

\footnotetext{
${ }^{53}$ HAHN, pp. 229-233. Sobre o ideal aristocrático de formação humana e, incidentalmente, suas concepções jurídicas, cf. JAEGER, pp. 23-60.

${ }_{54}$ HAHN, pp. 233-234.
} 
Como se pode aduzir do quadro apresentado, o desenvolvimento da $\pi$ ó $\lambda \iota \varsigma$, ao longo do período arcaico, foi caracterizado por lutas sociais que culminaram com o colapso da antiga dominação tradicional da aristocracia no seio do عُ $\theta v o \zeta$. Trata-se, vale repisar, do movimento que ocasionou a ascensão de $\delta i ́ \kappa \eta$, reveladora dos limites entre os homens, em detrimento da $\theta \varepsilon ́ \mu \iota \varsigma$ que regia a família extensa. O fato de ter sido um movimento marcado pela mudança do próprio paradigma cultural de direito denota o tamanho da instabilidade social que se deve ter verificado naqueles tempos.

Os conflitos ocasionados por essa situação de instabilidade social e a necessidade de consolidação da nova autoridade comunitária da $\pi$ ó $\lambda \iota \varsigma$ são elementos que podem ter justificado o surgimento das primeiras leis escritas entre os gregos. Nesse sentido, para Gagarin, a lei escrita decorreria de um esforço de consolidação e racionalização institucional no âmbito da expansão do poder da cidade. ${ }^{55}$

Deve-se ter sempre em conta o fato de que não há nenhuma evidência no sentido de que a lei tenha passado a ser estabelecida por escrito com vistas a preencher as necessidades de algum ideal democrático. Tão reproduzido entre comentadores modernos, o entendimento de que a lei escrita venha responder a anseios por garantias de igualdade e justiça corresponde mais a um ideal da Atenas do período clássico do que a uma intenção generalizada, especialmente no período arcaico. ${ }^{56}$

Há um texto de Aristóteles (Política, 1270b), no qual o filósofo, ao expor a constituição espartana, argumenta que os membros do Eforato, por serem escolhidos entre homens comuns, deveriam ter sua atuação adstrita à lei. Esta passagem é uma das fontes comumente tomadas pelos modernos para se estender anacronicamente a ideia do surgimento das inscrições legais como garante da democracia entre os gregos. Entretanto, além do fato de os espartanos serem notabilizados por seu repúdio à prática de escrever leis, o próprio Aristóteles, em outro momento da mesma obra (1272a), aponta a arbitrariedade dos julgamentos como um grave problema dos funcionários cretenses, muito embora seja entre os cretenses que tenha surgido um dos mais notáveis monumentos legais da antiga Grécia, o código das leis de Górtina. ${ }^{57}$

Monumento, aliás, é um termo bastante apropriado no que toca às diversas legislações escritas gregas, pois é característica comum a sua natureza epigráfica. Discorri,

\footnotetext{
${ }^{55}$ GAGARIN, p. 80.

56 Thomas, Rosalind. Letramento e oralidade na Grécia antiga. $1^{\mathrm{a}}$ ed. São Paulo: Odysseys. 2005, p. 94.

57 THOMAS, pp. 94, 203.
} 
no primeiro capítulo, sobre a semântica do vocabulário jurídico indo-europeu e sua natureza de manipulação material construtiva. A lei é uma pedra. Embora seja possível que, de início, tenha havido leis escritas em madeira e outros materiais perecíveis, a evidência literária e arqueológica aponta para a prática recorrente de inscrever os textos legais em monumentos de grandes dimensões, visíveis ao público. Se à primeira vista se pensa em um esforço para se franquear o acesso popular às leis, tal impressão não se sustenta com a análise do contexto social. A lei escrita não é condição suficiente para a instalação de uma situação de equidade. Entre os já referidos cretenses grassava o analfabetismo, de modo que pouca valia prática havia na exposição das leis, em termos de massificação do conhecimento. Ademais, é sabido que por muito tempo após o início da prática de se inscrever as leis em pedra persistiu o recurso a leis não escritas, sendo extremamente

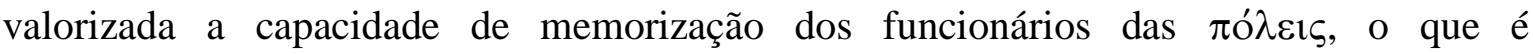
testemunhado inclusive pelos textos legais. ${ }^{58}$

A despeito da disseminação das legislações escritas, continuou a existir a figura dos $\mu \nu \eta ́ \mu o v \varepsilon \varsigma$, indivíduos que conheciam as leis ágrafas de cor, e que serviam de referência para a aplicação correta do direito. Da Creta criticada por Aristóteles em razão de seus juízes arbitrários vem o caso emblemático de Espensítios, ao mesmo tempo um $\mu \nu \eta ́ \mu o v$ e

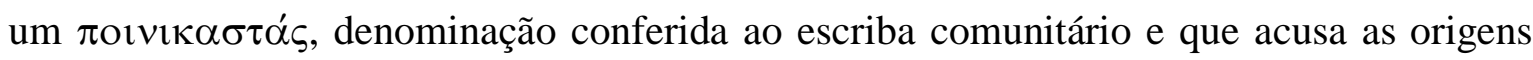
fenícias ("púnicas") da escrita alfabética grega. Ora, na qualidade de escriba e guardião da tradição oral, Espensítios simplesmente dominava todos os aspectos da aplicação do direito em sua comunidade, tanto oral quanto escrito. ${ }^{59}$

A convivência entre leis orais e escritas leva às contradições que se encontram no cerne da tragédia de Antígona, com o embate entre as leis ágrafas, de caráter religioso e familiar, e as normas escritas da $\pi$ ó $\lambda \iota \varsigma$ que se afirma perante as antigas famílias.

À vista dessas evidências, há que se buscar outras possíveis funções para a prática grega de tornar públicas as leis mediante inscrições monumentais. Para Hahn, a lei escrita não era a panaceia democrática, e sim o símbolo da autoridade da $\pi$ ó $\lambda$ เ aristocráticas resistentes à nova ordem. Thomas, em seu belo trabalho sobre o surgimento e as funções da escrita na Grécia, argumenta que a análise não deve se restringir à funcionalidade do texto escrito enquanto veículo de acesso à informação, mas deve considerar também o seu significado simbólico. Sendo verdade que as leis escritas

\footnotetext{
58 ThOMAS, pp. 92, 96-102, 202-209.

${ }^{59}$ THOMAS, pp. 97-99.
} 
dificultavam a manipulação dos conteúdos, ao mesmo tempo em que reforçavam normas que não contavam com a concordância generalizada da comunidade, forçoso admitir que tais fatores por si sós não conferem caráter coercitivo às leis. ${ }^{60}$

Muitas leis, não apenas do período arcaico, mas mesmo já na época helenística, traziam dedicações e invocações de divindades, imprecações e maldições. A sanção das leis do regime pós-aristocrático era fundada na religião da $\pi$ ó $\lambda \iota \varsigma$. A fundamentação religiosa aparece como uma maneira de rivalizar com o direito ágrafo dos aristocratas, sabidamente apoiado na autoridade divina. Lembre-se a discussão precedente sobre a $\theta \varepsilon ́ \mu ı \varsigma$, tida como um dom conferido pelos deuses aos reis homéricos (os monarcas heroicos de quem falava Aristóteles). Nesse sentido, Thomas ${ }^{61}$ :

\begin{abstract}
A inscrição de uma lei em pedra criava um memorial grandioso para todos verem, mas também um objeto físico que poderia ser mais facilmente dedicado à divindade e posto sob sua proteção. De modo semelhante, formular a lei escrita em forma de maldição era tomar um costume bem conhecido e adaptá-lo à grandiosa forma monumental. A inscrição em pedra monumental fora talvez inicialmente uma tentativa de dar às novas leis políticas e processuais o peso, o status - e, o mais importante, a proteção divina - que já eram concedidos às leis não escritas. Nisso, o uso principal e mais proeminente da escrita pela pólis arcaica, o impacto da escrita pode inicialmente ter sido amplamente o de conferir peso monumental e talvez autoridade religiosa à nova organização política da cidade-estado em desenvolvimento.
\end{abstract}

Gagarin está certo ao afirmar que as leis escritas refletem o enfraquecimento geral do poder das grandes famílias locais, e não um ideal de democracia ou justiça. Mas a função simbólica da lei é deixada em segundo plano por este autor. Gagarin não vê um ideal de justiça nas leis gregas deste período. E efetivamente não há. Mas é justamente por procurar e não encontrar tal ideal que ele acaba identificando as legislações gregas como normas de procedimento, o que tampouco reflete a essência daquelas leis. ${ }^{62}$

A lei escrita, portanto, atuou como um fator de neutralização do antigo direito, em favor do estabelecimento de uma nova ordem. A religião surge como outra frente aberta pelos aristocratas para tentar assegurar a manutenção de seu poder. Nesse sentido, o

\footnotetext{
${ }^{60}$ HAHN, pp. 52-53; THOMAS, pp. 99, 204-205.

${ }^{61}$ ThOMAS, p. 100.

${ }^{62}$ Por esta razão, Gagarin aborda o problema do surgimento do direito grego a partir da perspectiva de Hart, adotando o critério de normas de reconhecimento formulado por este autor. Contudo, me parece que o problema analisado por Hart, as fontes do direito, não coincide com o objeto em questão para os gregos, por ser um problema que emerge com a modernidade burguesa, embora em ambos os casos seja admissível a existência de um clamor subjacente por segurança, ainda que por razões diversas. Cf. GAGARIN, pp. 1-17, 99119.
} 
estabelecimento do culto dos heróis serviu à afirmação do poder social vigente em razão do estabelecimento de genealogias míticas que associavam os semideuses da tradição às famílias aristocráticas contemporâneas. Essa associação não se prestava exclusivamente ao reforço da legitimidade do domínio do عُقvos, mas também desempenhava importante função no contexto de luta pelo domínio das terras cultiváveis, porque ao se imputar ao antepassado heroico, provavelmente um totem do $\varepsilon$ $\theta v o \varsigma$, o domínio sobre uma região específica ou o seu sepultamento naquele local, se afirmava o direito de sua descendência ao domínio sobre a mesma terra. ${ }^{63}$

A respeito disso, basta refletir sobre a composição, mesmo muito tempo depois dos eventos em comento, de outra tragédia de Sófocles, Édipo em Colono, que ainda exibe com vigor a crença na conexão benfazeja existente entre o herói mítico e a terra que contém seus ossos, com as repercussões cúlticas decorrentes desse sepultamento no solo pátrio.

Mas o mais importante esforço político conservador na seara religiosa foi a prática do patrocínio aristocrático da construção de templos. Nessa época, as $\pi o ́ \lambda \varepsilon ı \varsigma$ ainda não se encontravam tão bem organizadas politicamente a ponto de conseguirem financiar obras de tal porte com os recursos do tesouro público, o que se tornaria usual no período clássico. É sabido que muitas personalidades da aristocracia, tiranos e mesmo reis remanescentes tomaram para si a iniciativa de financiar a construção de templos. Foi o que fizeram os Alcmeônidas em Delfos, o tirano Polícrates em Samos e o rei Creso em Mileto. O interesse em se promover esse tipo de construção é evidente, e se encontra em conexão com a busca de legitimidade proporcionada pela afirmação genealógica do culto dos heróis. Não apenas a construção de templos propiciava o controle social mediante a integração de grupos potencialmente desviantes nas manifestações ordenadas desenvolvidas no âmbito do culto, como também emprestava autoridade às classes dominantes. O patrocínio da construção acarretava aos olhos das massas a boa vontade da divindade em relação ao patrono, conferindo-lhe prestígio social e possibilidades políticas decorrentes, de modo que essas construções se tornassem $\theta \alpha u ́ \mu \alpha \tau \alpha$, maravilhas capazes de causar o "assombro" popular ante a imponência do templo e o esplendor de seu construtor, favorito da divindade padroeira do edifício, conferindo reforço ao status quo. Não por acaso, os atenienses, sob o regime democrático, rechaçaram a proposta de Péricles, que pretendeu pagar com seus próprios recursos a condução de obras públicas em Atenas, vez que aos olhos dos cidadãos

${ }^{63}$ HAHN, pp. $235-236$. 
tal oferta equivalia a uma indevida tentativa de arrogar para si a ampliação da autoridade, um risco à isonomia. ${ }^{64}$

Vale ressaltar, nesse sentido, que a religiosidade promovida pela aristocracia desempenhava função eminentemente conservadora, ao declarar a inescrutabilidade da natureza divina, com a qual o homem não pode pretender se medir, bem como a imprevisibilidade inerente ao destino humano. A ignorância quanto aos desígnios divinos

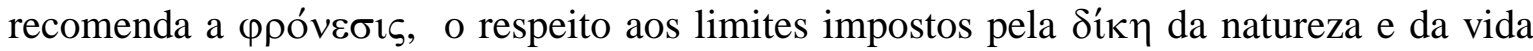
comunitária. Dessa forma, a desmedida, úßpıৎ, passa a ser considerada uma transgressão gravíssima, sujeita a severa punição por parte das divindades.

A religião grega, portanto, em função de um pessimismo da razão no que concerne à sua capacidade de alcance da compreensão holística do homem sobre o cosmo, promove uma ética oposta à que se encontra na espiritualidade judaico-cristã, uma vez que desencoraja a imitação do deus. Este, tomado pelo sentimento de "ciúme divino", o $\varphi \theta$ óvos $\theta \varepsilon \hat{\omega} v$, punirá todo o excesso de qualidades ou defeitos, a fim de moderar a existência humana por meio da punição da arrogância. Nesse sentido, a ética religiosa da Grécia arcaica foi eficaz em reservar o sucesso à divindade e negá-lo ao homem - ao menos como resultante de sua iniciativa e responsabilidade -, traduzindo-se em uma moral negativa, pois delimitada majoritariamente por tabus, e não por mandamentos. Ademais, ressalte-se que o monopólio da manutenção e refinamento da cultura por uma minoria impede a expansão da civilização, o que é via de regra uma empreitada coletiva, seja por meio do comércio ou da guerra. ${ }^{65}$

Sobre a construção dos templos, diz Hahn ${ }^{66}$ :

Thus, the house of the goddess was not to be inhabited by mortals and yet its design and awesome proportions were intended to overwhelm and impress the visitor to the sanctuary; the temple design was an expression that the archaic community came to regard as appropriate to honor the highest and best. In this sense, by means of the house-building tradition, patronized by archaic aristocrats, the ruling class externalized their internal vision of kalos kai agathos, the most beautiful and best in their community. Stated differently, they sought to externalize themselves and further secure respect and authority at a time when the challenges to authority and control of land were on the increase. In the process, the aristocratic plan was to enhance their rightful authority; they

\footnotetext{
${ }^{64}$ HAHN, pp. 223-226, 234-238.

65 JAEGER, pp. 23-36; ZOJA, Luigi. História da arrogância: psicologia e limites do desenvolvimento humano. S. ed. São Paulo: Axis Mundi. 2000, pp. 36-37, 43-46.

${ }^{66}$ HAHN, p. 74.
} 
sought to reinforce their dominant position by externalizing the vision of the highest and best by overwhelming their communities through patronage of monumental proportions and sought to align themselves with the best and most powerful forces in nature. And no one should doubt that the development of the sanctuary provided a social vehicle by which the disparate elements in the thriving city could be organized cohesively.

Havia, portanto, razões políticas que alimentavam uma grande demanda pela construção de templos, em dimensões cada vez mais monumentais, até então nunca realizadas por construtores gregos. Isso acarretou a necessidade prática de elaboração de tratados de arquitetura em prosa, a fim de disseminar o conhecimento técnico necessário. Atribui-se a Teodoro, arquiteto responsável pela construção do templo de Hera em Samos, a invenção de certos instrumentos, tais como a régua e o relógio solar, além de métodos que lhe permitiram aferir o êxito de operações de terraplenagem, mediante o uso de um peso amarrado no vértice de uma estrutura triangular, e desviar o curso de um rio para viabilizar a construção do templo. O culto de Hera, deusa relacionada à fertilidade, demandava a construção do templo em área pantanosa, fonte de vida por excelência. Por volta daqueles anos, perto dali, em Mileto, Tales anunciava a água como $\alpha \rho \chi \eta \dot{~}{ }^{67}$

Note-se que muitos êxitos idênticos àqueles obtidos pelos arquitetos no campo da geometria aplicada são atribuídos pela tradição aos primeiros filósofos. Diz-se que Anaximandro teria sido o introdutor do relógio solar na Grécia. Tales, por sua vez, conseguia estimar a altura da pirâmide de Quéfrem e a distância de navios no mar por meio das mesmas relações do triângulo que fundamentam o funcionamento do instrumento de medição de Teodoro, além de ser conhecido por ter desviado o curso de um rio para permitir a passagem das tropas do rei Creso. Tales é retratado como um homem que acreditava que o cosmo é dotado de uma ordem cujo conhecimento é acessível aos mortais, permitindo-lhes interferir na natureza, o que está no fundamento da $\tau \dot{\varepsilon} \chi v \eta$ arquitetônica. Havia muita competição entre os arquitetos em atividade na Jônia, todos ávidos de demonstrar a superioridade de seu gênio. Enquanto a prosa de Ferécides, discutida logo adiante, ainda possui caráter patentemente subordinado à literatura oral, servindo de suporte e memória à performance de um aedo, os tratados arquitetônicos e os textos filosóficos jônicos possuem os mesmos intentos de informar acerca de uma compreensão

${ }^{67}$ HAHN, pp. 61-65, 72-73. 
da natureza e documentar ou testemunhar o êxito de tais reflexões. Ambas as vertentes da prosa se igualavam em sua função de instrução e celebração. ${ }^{68}$

Muito embora o ofício do arquiteto deva o seu florescimento ao patrocínio aristocrático da construção de templos, vê-se que a sua $\tau \dot{\varepsilon} \chi v \eta$, desenvolvida em bases racionais e práticas por tentativa e erro, viabilizou importantes alterações na mentalidade dos gregos, que conduziram a um processo de desencantamento cujos atores mais conhecidos são os primeiros filósofos. A $\tau \dot{\varepsilon} \chi \vee \eta$ da arquitetura demonstrou que a natureza possui uma estrutura definida e determinada, cujo conhecimento permite aos homens realizar grandes obras. A previsão quanto ao comportamento dos materiais, a manipulação de grandes colunas e blocos de pedra, o traçado das dimensões do prédio no terreno, o planejamento da estrutura e a tensegridade do conjunto exigiram um planejamento cada vez mais racionalizado de todos os fatores envolvidos na construção. Uma percepção equivocada sobre o comportamento da estrutura ou do terreno poderia acarretar um colapso estrutural, com sérios riscos à vida de um grande número de pessoas, para não mencionar a superveniência de enormes prejuízos financeiros. ${ }^{69}$

A possibilidade de compreender uma natureza impessoal é a grande novidade cosmológica trazida da arquitetura pelos filósofos milésios, que, como figuras de transição, convivem com personagens que propõem explicações cosmológicas comprometidas com o esquema anterior, cosmogônico. O exemplo mais notável é o de Ferécides de Siros. Sua cosmogonia se inicia com Zás, Ctônia e Chronos, entidades que sempre teriam existido, o que denota, da mesma maneira que a enumeração das gerações divinas hesiódicas, a busca de uma solução para o paradoxo da criação ex nihilo. Zás e Ctônia se unem em matrimônio; aquele fabrica, como presente de casamento para a noiva, um tecido no qual estão estampados a superfície terrestre e Oceano. Em seguida, Zás cria um carvalho alado (!), por sobre cuja copa abobadada lança o tecido terrestre, configurando, desta forma, um mundo não mais discoide, como na cosmogonia de Homero, mas convexo. Abaixo do carvalho divino, está o quinhão do Tártaro, morada dos mortos. Enquanto tudo isso se

\footnotetext{
${ }^{68}$ HAHN, pp. 55-58, 64-66, 76-77, 80-81.

${ }^{69}$ HAHN, pp. 84-85. Sobre os métodos, vestígios e características gerais da arquitetura do período jônico arcaico, RoberTSON, D. S. Arquitetura grega e romana. 1a ed. São Paulo: Martins Fontes. 1997, pp. 107-123.
} 
sucede, Chronos trava combates com outras entidades e dá origem a divindades e seres diversos por meio da masturbação. ${ }^{70}$

Ferécides escreve em prosa, mas a essência de seu tratamento das origens cósmicas é poética. É verdade que não aceita que as divindades tenham surgido do vazio, mas também é fato que tenha aceitado explicações de caráter popular, tais como as fundações "vegetais", por assim dizer, da Terra. Embora haja controvérsia quanto à época em que se situou sua vida e produção literária, todos os testemunhos da Antiguidade e as ponderações modernas convergem para algum momento entre Hesíodo e Pitágoras (que, segundo alguns relatos, teria sido seu aluno), o que coloca a possibilidade dramática de que as figuras tão díspares de Ferécides e de Anaximandro tenham sido contemporâneas.

Nessa época surgia a prosa arquitetônica, para assentar os conhecimentos técnicos relativos à construção de estruturas monumentais. É sabido que já os gregos do período micênico haviam sido responsáveis por obras de grandes dimensões. Entretanto, o conhecimento arquitetônico micênico havia sido perdido em decorrência da desorganização da civilização urbana acarretada pela invasão dórica. Os condutores da reurbanização e da construção dos grandes templos, séculos depois da derrocada de Micenas, tiveram que recorrer a outras fontes para obter o know-how exigido para tais obras, o que foi obtido, segundo Hahn, com os egípcios, detentores de mais de dois mil anos de conhecimento e prática contínuos em construção de templos e monumentos, bem como de tentativas de construção de canais. A oportunidade para a absorção da $\tau \dot{\varepsilon} \chi v \eta$ arquitetônica e de engenharia de águas surgiu com a atuação dos milésios e dos habitantes de outras cidades da Jônia como construtores navais, marinheiros e mercenários para os egípcios, entre os séculos VII e VI a. C., tempo do Faraó Psamético e de seus sucessores imediatos, aliança que propiciou a Mileto o privilégio de fundar o entreposto comercial de Náucratis, no delta do Nilo. ${ }^{71}$

Para que se possa depreender o que seria o porte de uma construção monumental no contexto do estilo jônico arcaico, apresente-se o templo de Ártemis patrocinado por Creso em Éfeso e descrito pelo historiador da arquitetura Robertson ${ }^{72}$ :

\footnotetext{
${ }^{70}$ KiRK, G. S. RAVEn, J. E. SChOFIELD, M. Os filósofos pré-socráticos. $6^{\mathrm{a}}$ ed. Lisboa: Calouste Gulbenkian. 2008, pp. 45-68; Hahn, 50-51.

${ }^{71}$ HAHN, pp. 66-69.

${ }^{72}$ ROBERTSON, pp. 108-109.
} 
O templo de Creso propriamente dito foi um empreendimento de monta, executado com uma liberdade e uma variedade que lembram a arquitetura medieval. O degrau superior media mais de 54,5 m por aproximadamente $109 \mathrm{~m}$ e a cela era circundada por um pteroma duplo formado por enormes colunas - a fileira exterior compunha-se de oito nas fachadas e vinte ao longo das laterais. $O$ eixo, como de hábito, corria na direção leste-oeste, mas o acesso, contrariando a norma, dava-se pelo oeste. As colunas eram de mármore maciço, mas o cerne das paredes, revestidas também com mármore, era em calcário. Havia um profundo pronaos in antis, que provavelmente continha oito colunas em quatro pares e haveria ainda ou um ádito ou um opistódomo. É provável que existissem colunas internas, mas sua localização é hipotética: Plínio, o Velho, afirma que havia um total de 127 colunas, mas é possível que tal fosse verdadeiro apenas no caso do templo do século $\mathrm{IV}$.

As técnicas egípcias de construção incluíam o uso de plantas em plano aéreo. É bastante provável que essa prática tenha sido apresentada aos construtores gregos, pois, muito embora não haja evidência sobrevivente de plantas entre os gregos (achadas no Egito, apesar de não terem sido encontrados exemplares feitos em escala, cuja existência entre os egípcios é discutida), sabe-se que os construtores gregos faziam o desenho das estruturas no próprio solo, em escala 1:1, demarcando o exato lugar a serem erguidas as paredes e colunas, prática comum entre os egípcios desde o Antigo Império. Ademais, os

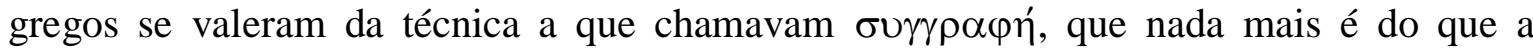
descrição textual das estruturas e dimensões a serem empregadas em cada construção.

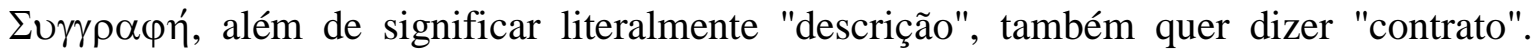

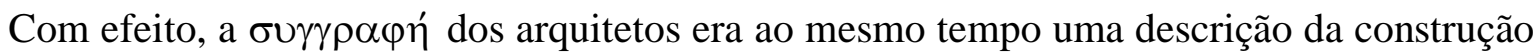
a ser realizada e o instrumento de contrato da obra, por meio do qual o patrono aristocrata aprovava o projeto. ${ }^{73}$

Uma das mais importantes inovações trazidas do Egito pelos pioneiros da arquitetura megalítica na Jônia foi a técnica para a edificação das colunas dos templos. Com os egípcios, os gregos aprenderam as facilidades decorrentes da substituição das colunas monolíticas (que demandavam grandes esforços para serem talhadas, transportadas e posicionadas) por tambores de coluna, cilindros de pedra atarracados que deveriam ser sobrepostos para formar uma única coluna. A estabilidade da coluna formada por diversos tambores sobrepostos sem o uso de argamassa era assegurada por meio de duas técnicas principais, a anatirose e o empólio. A primeira técnica consistia em escavar as superfícies inferior e superior de cada tambor, tornando-as côncavas, de modo que a parte central da superfície superior de um tambor não estivesse em contato com a superfície inferior do

${ }^{73}$ HAHN, pp. 97-120, 137. 
tambor que se lhe sobrepusesse, o que eliminava a necessidade de polir totalmente essas faces para propiciar o encaixe adequado, bastando que se polisse as bordas das superfícies. Por vezes, apenas o ponto mais central do tambor não era escavado, a fim de que ali se fizesse um orifício circular ou quadrado, para receber uma pequena peça (na forma correspondente de um cilindro ou de um paralelepípedo), encaixada como um eixo entre um tambor e outro, para que estes não deslizassem para as laterais, o que consiste na técnica do empólio. ${ }^{74}$

As colunas constituíam elementos muito importantes do templo grego, havendo diversas hipóteses a respeito de seu simbolismo. Uma das explicações possíveis apresenta a coluna como um elemento de separação entre a terra e o céu, simbolizando o eixo central do cosmo. Ademais, o fato de a evolução das plantas dos templos ter forçado o deslocamento das colunas, antes localizadas dentro do recinto do templo, junto ao altar, para os limites da construção, a fim de suportar o peso do telhado, concentrou o foco do culto no centro do prédio, onde se localizavam a estátua do deus e o fogo ritual, o que foi entendido por alguns comentadores como a possível explicação para o entendimento grego de que a posição central no espaço contém o poder, aspecto que retomarei mais adiante. ${ }^{75}$

À vista da figura da coluna como eixo cósmico que divide céus e terras, não é de se estranhar que a Terra, no modelo cosmológico de Anaximandro, tenha tomado a forma de um tambor de coluna interposto no cosmo. Não se trata de projetar no universo as características de um símbolo feito pelo homem, mas de descrever o cosmo em concordância com uma figura que já é considerada - ainda que por conta de um pressuposto cultural que não herdamos - a forma do eixo cósmico. De acordo com os relatos referentes ao modelo do cosmo, o tambor terrestre, assim como os das colunas dos templos, tem altura equivalente a um terço de sua largura. Sua face superior, que é a superfície habitada da Terra, é côncava, do mesmo modo que a superfície escavada do tambor de coluna conforme o método da anatirose. O conjunto formado pela coluna terrestre e pelas órbitas das estrelas, da lua e do sol delineia um diagrama muito similar à mesma imagem da superfície escavada da coluna, situando-se a Terra na posição central, imóvel tal como a peça encaixada do empólio. Sem ter ele próprio deixado algum desenho conhecido do modelo cosmológico, Anaximandro o teria descrito à moda de uma verdadeira $\sigma u \gamma \gamma \rho \alpha \varphi \eta ́$, na qual se diz ter estabelecido a distância entre a Terra e os discos

\footnotetext{
${ }^{74}$ HAHN, pp. 76, 149-162; ROBERTSON, p. 51.

${ }^{75}$ HAHN, pp. 86-95.
} 
das estrelas, da lua e do sol, respectivamente, em 9, 18 e 27 diâmetros terrestres. O aspecto fundamental a ser considerado nessa proporção não é o respeito à tradição hesiódica das distâncias contadas em múltiplos de nove, mas o raciocínio da arquitetura dos templos, que define as dimensões do conjunto a partir das medidas de um objeto central. ${ }^{76}$

A identificação do cosmo de Anaximandro com a figura de uma superfície de coluna à qual se aplicou as técnicas de anatirose e empólio só é possível se o modelo for visto a partir do alto, isto é, mediante o emprego da perspectiva em plano aéreo, uma inovação de proveniência egípcia na arquitetura megalítica do período. Muitos, à vista do modelo e de suas órbitas circulares, cogitaram que o cosmo proposto por Anaximandro tivesse forma esférica, o que não procede, pois o movimento giratório dos corpos celestes em torno da Terra constitui um sólido de revolução virtual, de forma cilíndrica, desenhando a coluna que é o próprio eixo cósmico. Com efeito, Anaximandro deve ter se valido de todas as possibilidades oferecidas pelo estado da arte, pois, como conclui Hahn, a partir dos estudos de Couprie, apenas a perspectiva tridimensional de uma coluna inclinada permite ao modelo explicar o movimento aparente do sol ao longo do ano. ${ }^{77}$

A Terra se encontra fixa no centro, como o empólio. Muito se discutiu sobre a natureza dessa fixidez. Aristóteles diz que a Terra permanece no centro porque se situa em ponto equidistante dos extremos, em equilíbrio estático, portanto, porque não sofre qualquer impulso para nenhum dos lados. Simplício, por seu turno, sustenta que a Terra se encontra imóvel em razão do movimento dos discos dos diversos corpos celestes, que constituiria um vórtice que mantém o cilindro terrestre em equilíbrio dinâmico. A equidistância aventada por Aristóteles condiz com a perspectiva em plano aéreo, já que nesta a Terra aparece como um círculo. Mas, se mantido o plano aéreo e pensada a Terra como um cilindro, não há como subsistir a característica de equidistância. A dualidade de perspectiva arquitetônica - plano aéreo e tridimensional - se apresenta como a única possibilidade de conservação da explicação fornecida por Aristóteles. ${ }^{78}$

A imagem do vórtice é poderosa para a compreensão da formação desse sistema cósmico descrito por Anaximandro. Do mesmo modo como a cosmogonia hesiódica pressupõe que o mundo tenha passado por vários estágios ou gerações até chegar à sua configuração atual, o modelo de Anaximandro não é formulado ex nihilo; ao contrário,

\footnotetext{
${ }^{76}$ HAHN, pp. 137-148, 180-198.

${ }^{77}$ HAHN, 200-218.

${ }^{78}$ HAHN, 198-200.
} 
denota a existência de um mecanismo que possa ser explicado, no que muito difere das cosmogonias elaboradas por Hesíodo e Ferécides, embora Hahn também chame, impropriamente, o processo impessoal descrito por Anaximandro - talvez por falta de

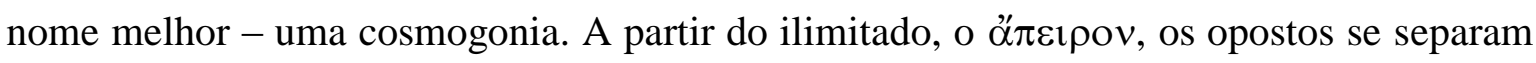
em um movimento eterno, como o de uma roda de carroça, progressivamente fundindo-se em uma roda de fogo com a mesma aparência dos anéis de um tronco de árvore (as árvores, recorde-se o que disse Cornford, foram os primeiros templos; apenas muito depois são substituídas pelas colunas de pedra) da qual se formam os diversos astros, em torno da Terra úmida. ${ }^{79}$

Presente no seguinte trecho de Simplício (Physica, 24, 17), encontramos o único fragmento subsistente de Anaximandro, que descreve esta dinâmica determinada pela

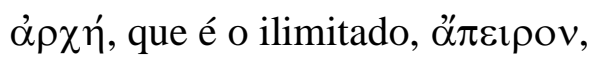

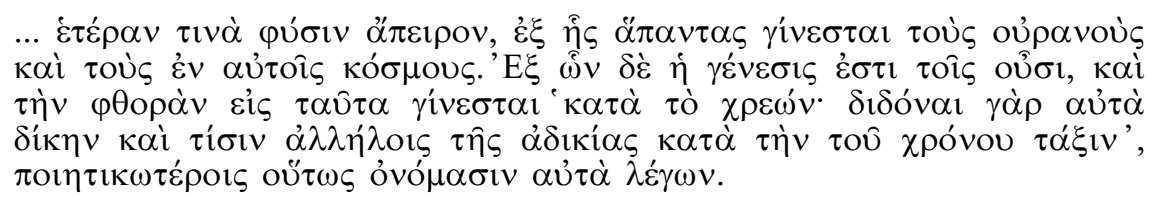

que se traduz, comumente, da maneira seguinte:

... uma outra natureza ilimitada, de que provêm todos os céus e mundos neles contidos. E a fonte da geração das coisas que existem é aquela em que a destruição também se verifica "segundo a necessidade; pois pagam castigo e retribuição umas às outras, pela sua injustiça, de acordo com o decreto do tempo", sendo assim que ele se exprime, em termos assaz poéticos.

A narrativa cosmogônica de Ferécides e as descrições cosmológicas de Anaximandro se inscrevem no número dos primeiros textos gregos em prosa. Anaximandro é claramente influenciado em sua mundivisão pelos métodos da arquitetura de base egípcia desenvolvida na Jônia, igualmente veiculada em prosa. Concomitantemente, surgem, também sob forma prosaica, as legislações das $\pi$ ó $\lambda \varepsilon ı \varsigma$ que chegaram até nós. Anaximandro parece ter sido também de alguma forma influenciado pelos textos legais, não apenas em estilo, mas igualmente quanto ao vocabulário de que se vale, o que tem confundido os intérpretes, que veem em sua prosa a descrição de uma natureza dotada de caráter antropomórfico.

${ }^{79}$ HAHN, 188-193. 
Anaximandro é o primeiro a colocar esse processo por meio de um vocabulário que facilmente identificamos com a linguagem das leis e dos tribunais. Para muitos comentadores contemporâneos, isso indica tratar-se o fragmento de um dito metafórico,

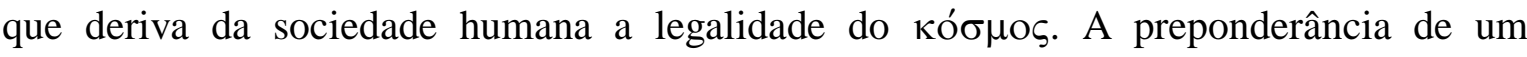
elemento sobre o seu contrário constitui um ato de injustiça - $\alpha \delta$ เ

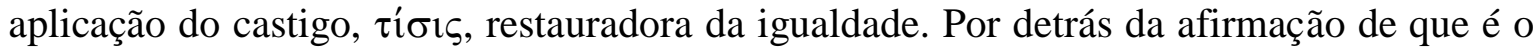
Tempo quem profere a sentença, há a ideia de inevitabilidade da punição, além da noção de que esta se dá após certo prazo. Dado ser o par de opostos mais presente nos filósofos pré-socráticos aquele composto de quente-frio ou seco-úmido, é fácil imaginar a superveniência regular das estações como um bom exemplo da punição entre os opostos de acordo com o decurso do tempo certo.

A explicação da gênese e da destruição dos elementos e dos mundos a partir da interação de substancias contrárias poderia ser uma herança da explicação de ordem sexual do modelo cosmogônico anteriormente predominante? É possível que sim, e semelhante possibilidade permitiria ir além, para aventar ainda que a metáfora jurídica em Anaximandro, assim como o fora a alegoria matrimonial cosmogônica, opera com base em um mecanismo de personificação dos elementos naturais.

Esta seria a coroação perspicaz de uma explicação definitiva do fragmento, não

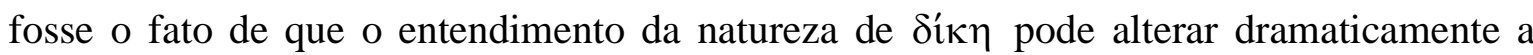

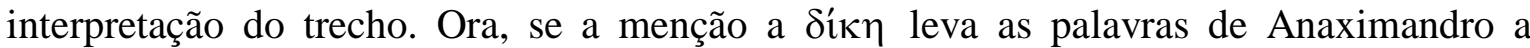
assumir natureza "assaz poética", mesmo já aos olhos de Simplício, isto se deve à evolução semântica posterior do termo, que apenas tardiamente incorpora o sentido ético de justiça.

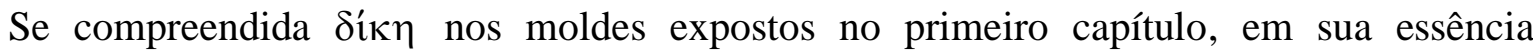
primordial de uma palavra in-dic-adora de limites naturais, percebe-se que ela não se limita aos negócios humanos - antes, abarca-os. Naquele capítulo, tive a oportunidade de

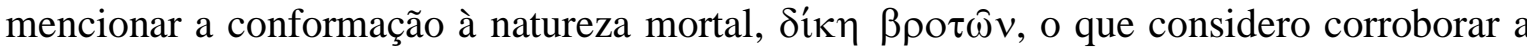
pertença de a um patamar maior que o próprio homem, que nela está incluso.

No mesmo espírito, de que outra maneira poderíamos interpretar, sem recorrer à fácil solução da metáfora, o seguinte fragmento de Heráclito (fr. 94 DK): "H $\lambda$ ıos oủ $\chi$

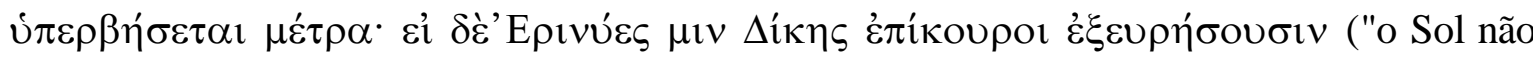
transporá os seus limites: caso contrário, as Erínias, executoras da justiça, saberão descobri-lo")? 


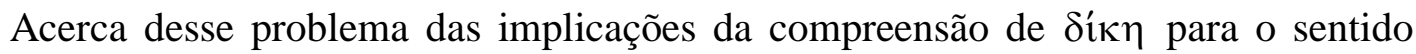
humano dos fragmentos dos pré-socráticos, veja-se o comentário de Heidegger a respeito do fragmento de Anaximandro. O filósofo alemão apresenta uma interpretação demasiadamente sofisticada do dito de Anaximandro, a fim de demonstrar que os comentadores que creem tratar o fragmento exclusivamente do domínio do "natural", de algo alheio ao homem, partem do pressuposto aristotélico de que a noção de entes, $\tau \grave{\alpha}$

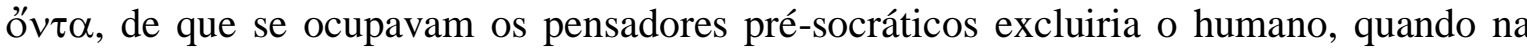
verdade se refere à multiplicidade daqueles entes em sua totalidade, o que abarca o divino, ao lado dos homens e das coisas criadas pelos homens, assim como de todos os eventos e estados causados pela ação ou omissão do homem. ${ }^{80}$

Haveria, por assim dizer, uma ontologia pré-aristotélica que incluísse em seus domínios o campo da técnica e seus produtos, como elementos integrantes do Ser e que repercutem no âmbito do Ser.

Dessa forma, não subsistisse o dogma interpretativo aristotélico da restrição do enunciado às coisas da natureza, não haveria mais como afirmar que aquilo que pertence ao domínio das ciências naturais fora dito de maneira metafórica, pois também o moral e o jurídico passariam a ser abrangidos pela realidade afirmada no fragmento. Inexiste mesmo a especialização dos saberes, não cabendo falar em intrusão do vocabulário de uma área por outra. O sentido dos termos é amplo, o que não quer dizer que seja impreciso, e sim que subjaz, de maneira enriquecedora, a uma variedade de situações. ${ }^{81}$

A compreensão heideggeriana abrangente dos őv $\tau \alpha$, objeto do discurso de Anaximandro, é formulada a partir da seguinte passagem da Ilíada (I, vv. 68-72):

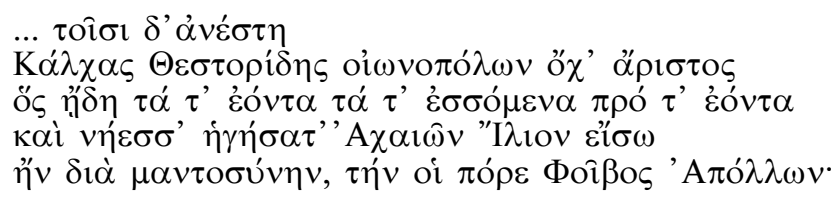

assim traduzida:

... de novo se ergueu

Calcas, o Testórida, o mais sábio dos videntes,

Que via o que é, o que será e o que foi,

\footnotetext{
${ }^{80}$ HeidegGer, Martin. La sentencia de Anaximandro. In: Caminos de bosque. $1^{\text {a }}$. ed. Madrid: Alianza. 2008. pp. 239-277, pp. 245-246.

${ }^{81}$ HeIDEGGER, p. 246.
} 
Interessante notar que o atributo do vidente é ser aquele que via, ö $\zeta \not \emptyset \eta$, vale dizer, a ação de prever pertence ao passado. Prever é ter visto com antecipação. Para tanto, o que é visto é aquilo que, existente, não é percebido em razão de estar ausente, fora do alcance da visão. O que faz o vidente é atravessar com sua visão o encoberto, para enxergar o ausente, é subtrair-se momentaneamente por meio do frenesi, do transe, para ter acesso ao ausente. $^{82}$

Isto parece ser confirmado pela caracterização dada por Homero àquilo que é visto:

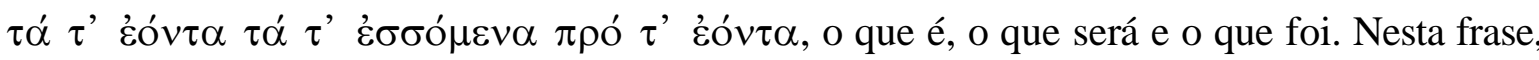

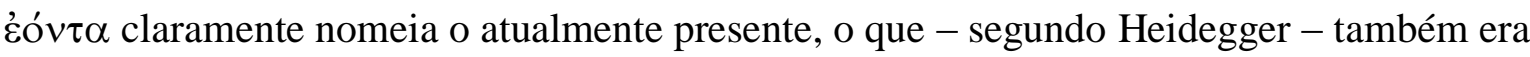
chamado entre os gregos $\tau \grave{\alpha} \pi \alpha \rho \varepsilon o ́ v \tau \alpha$, onde $\pi \alpha \rho \alpha$ significa "junto a", ou seja, o que está presente, o que é presente - entre o passado e o futuro. ${ }^{83}$

Com efeito, o equivalente latino literal de $\pi \alpha \rho \varepsilon o ́ v \tau \alpha$ é praesens, "presente". O que ocorre no presente é aquilo que ocorre às claras, na comarca do desocultamento. Com isso, pode-se entender a ambiguidade de nossa palavra presente, que se refere simultaneamente ao que é percebido no tempo e no espaço atuais. Praesens é também o particípio de praeesse, que significa "ser o primeiro", "comandar", "presidir".

O que está em evidência no presente se rebela contra a mera duração, anseia por permanecer na comarca do presente, onde mora - e demora - para evitar mergulhar novamente no oculto. Essa permanência extemporânea é o que Heidegger identifica como

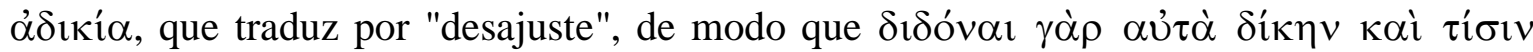

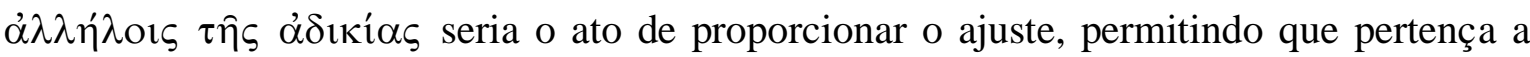
outro o que atualmente é seu, o ajuste com relação à procedência e à partida. O que mora provisoriamente em cada instância habita o ajuste que ajusta a presença em face da dupla ausência. $^{84}$

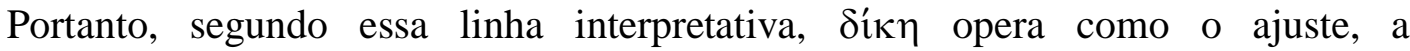
conformação. Ao longo de toda a presente reflexão apresentou-se a palavra em comento

\footnotetext{
${ }^{82}$ HeIDEGGER, pp. 256-258.

${ }^{83}$ HeIDEGGER, p. 257.

${ }^{84}$ HeIDEGGER, pp. 262-265.
} 
nesses exatos termos, como um indicativo de limites do mundo, abarcando com isso o âmbito humano.

O filósofo está correto ao tomar como pressuposto de sua análise a pertença do mundo humano da $\tau \dot{\varepsilon} \chi \vee \eta$ à totalidade da $\varphi v ́ \sigma ı \varsigma$, o que lhe permite efetivamente chegar à compreensão exata do sentido de termos como acordo com um parâmetro indicativo preexistente. No entanto, deve-se frisar que há um problema fundamental na interpretação oferecida por Heidegger, pois ela nos leva a desconsiderar a relação entre a literatura cosmológica e os primeiros textos legais.

A partir do fato de que o uso do vocabulário de Anaximandro não é metafórico e que não havia especialização do conhecimento entre os antigos, o pensador alemão simplesmente passa a sustentar que não tenha havido qualquer intercâmbio entre o pensamento filosófico e a atividade legiferante, colocando todas as consequências do pensamento contido no fragmento de Anaximandro na seara estritamente filosófica, que apenas concerne ao homem pelo fato de este estar inserido com todos os seus negócios na multiplicidade dos entes. Ao combater a concepção de que o fragmento de Anaximandro teria sido escrito em termos "assaz poéticos", Heidegger corre para o lado oposto, oferecendo uma interpretação que põe o texto em termos puramente ontológicos, "assaz abstratos".

Não posso concordar com a eliminação do espectro social que informa o pensamento do filósofo de Mileto. Seja pela fraseologia, seja pela estrutura do texto, não há razão para desconsiderar as implicações políticas diretas do dito de Anaximandro. É verdade que é muito pouco dizer que Anaximandro simplesmente se apropriou de uma terminologia de tribunal para descrever o cosmo, mas, se é possível concluir pela validade simultânea do fragmento para o mundo humano e para a totalidade, segue-se que isso se deva ao esforço de enquadrar a imprevisibilidade dos assuntos políticos em um esquema cósmico, especialmente em um ambiente político conturbado como o de Mileto e de toda a Jônia. Os fragmentos dos filósofos não são os primeiros textos cosmológicos em prosa, pois foram antecedidos nessa matéria pelas legislações. Como diz $\mathrm{Hahn}^{85}$ :

Anaximander, the politically active member of his community, credited with founding the colony of Apollonia (on the Black Sea?), sought to foretell for his fellow Milesians the ultimate prevailing of justice in human matters on the

${ }^{85}$ HAHN, p. 24. 
grounds of order and justice-preserving procedures he discovered in the cosmos. And like the legal procedures, they were written down in prose.

A muitos comentadores custa aceitar que era esperado de um filósofo grego a versatilidade, a incursão por uma diversidade de searas do conhecimento, uma vez que o paradigma grego do бoழós pressupõe a condição de polímata, aquele aspecto da personalidade de Pitágoras tão severamente censurado por Heráclito (fr. 40 DK). Ademais, a abordagem de Heidegger se aproxima da análise dos estudiosos presos à concepção platônico-aristotélica e cristã do marco ontológico da filosofia. O problema da ontologia como o cerne da tradição filosófica e a preponderância do pensamento diretamente devotado ao Ser em relação ao conhecimento sobre a realidade física induz a $\tau \dot{\varepsilon} \chi \nu \eta$ a um papel secundário, vez que esta, aparentemente, nada pode dizer diretamente sobre o problema ontológico: apenas a transcendência dos sentidos dá acesso ao conhecimento dos objetos reais. ${ }^{86}$

Conforme já exposto, deve-se à $\tau \dot{\varepsilon} \chi \nu \eta$ arquitetônica contribuições basilares para o desenvolvimento da filosofia milésia. A argumentação de Heidegger não está em condições de assimilar este fenômeno, e só o que lhe resta é tentar encontrar na estrutura da linguagem, em si e por si, uma filosofia completa.

Também Kahn contesta a opinião de que o vocabulário de Anaximandro seja indicativo de uma expressão poética, ao asseverar que a fraseologia do fragmento não pertence à língua artificial dos poemas épicos, mas corresponde efetivamente à linguagem

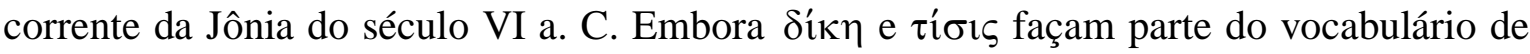
Homero, essas palavras jamais ocorrem, nos poemas, em associação à forma verbal $\delta 1 \delta o ́ v \alpha 1$. Daí Kahn afimar que the fragment of Anaximander represents the earliest example of what must have been a very common phrase in the law courts. No entanto,

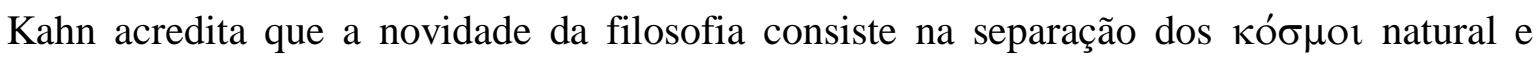
humano, cuja unidade, na visão do autor, é uma característica inerente ao pensamento préfilosófico. $^{87}$

Ora, o que se segue da argumentação que busca relacionar o surgimento da filosofia ao desenvolvimento das formas da $\tau \dot{\varepsilon} \chi \nu \eta$ é exatamente o oposto, a saber, que a unidade

\footnotetext{
${ }^{86}$ HAHN, pp. 80-83.

${ }^{87}$ KAHN (1994), pp. 168-170, 190-193.
} 


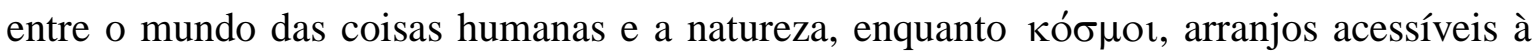
razão humana, é um pressuposto da filosofia nascente.

Dito isso, retome-se um problema anterior. Conforme aventado, a planta do templo grego é uma das possíveis origens para a concepção de que o poder está localizado sempre na posição central do espaço. Há várias formas de poder. Em outros momentos, foi

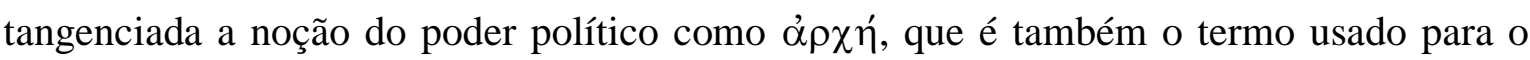
elemento primordial buscado pelos filósofos milésios. Mas o poder também é expressado

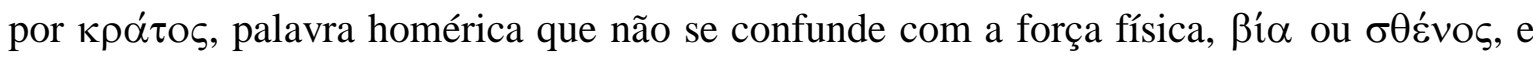

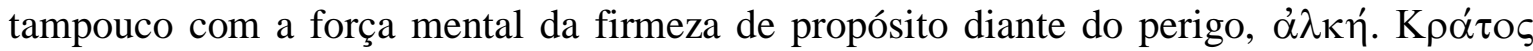
serve para designar tanto o poder prevalecente por conta da superioridade na batalha quanto o exercício político do poder, por meio da autoridade perante o $\lambda \alpha \alpha_{\circ} \varsigma$, a assembleia de guerreiros, no que mais se aproxima da noção de poder político. ${ }^{88}$

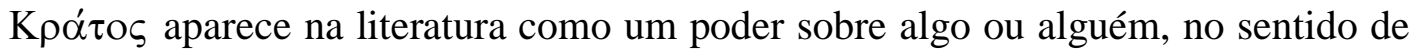
se conseguir assimilar ou dominar o seu objeto. Já se tratou da Terra, que permanece no centro, por si só, a despeito de não ter quem a domine - ن́đò $\mu \eta \delta \varepsilon v o ́ \varsigma \kappa \rho \alpha \tau o u \mu \varepsilon ́ v \eta v$. Também Anaxímenes tratou desta dominação como inerente à relação entre os elementos, ao comparar o Ar circundante do mundo com a alma que domina ( $\sigma \mho \gamma \kappa \rho \alpha \tau \varepsilon \hat{)}$ o corpo. Esta palavra é usada pela medicina grega com o significado de "digestão", enquanto que as inscrições legais a usam para expressar o direito de reter ou dispor de algo, bem como a noção correlata de ser o mestre ou proprietário de algo. Disto se conclui, segundo Vernant,

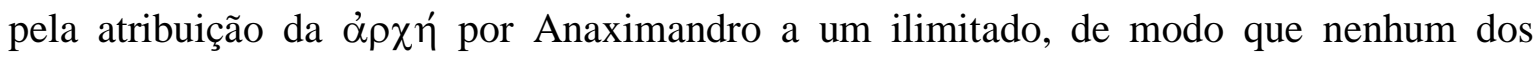

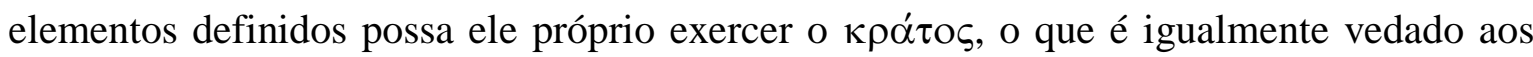
particulares na cidade em que impera a isonomia. Este ilimitado é também a origem dos demais elementos, o que é bastante interessante por representar a reunião do poder do

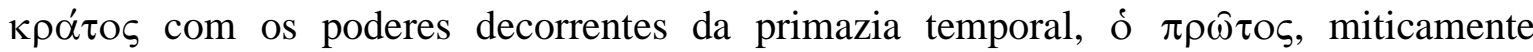
dissociados nas figuras de Cronos e Zeus. O ö́єєıрov, o ilimitado de Anaximandro, não é um monarca, mas tal como a lareira pública, um mediador que promove a similitude entre os elementos circundantes. A própria Terra, por sua posição centralizada no cosmo, é denominada lareira por Anaximandro e pelos astrônomos dos períodos posteriores. ${ }^{89}$

\footnotetext{
${ }^{88}$ BENVENISTE, vol. 2, pp. 71-83.

${ }^{89}$ KAHN (1994), pp. 80-81. VERNANT, Jean-Pierre. Mito e pensamento entre os gregos: estudos de psicologia histórica. $2^{\mathrm{a}}$ ed. São Paulo: Paz e Terra. 2008, pp. 259-283.
} 
Mais acima foi exposto que a centralidade é uma característica da expressão espacial do poder, que alguns analistas entendem ser a chave para uma genealogia da isonomia no pensamento político a partir do simbolismo religioso da arquitetura do templo grego, que dispõe as colunas, possíveis representações de seres humanos, na periferia da construção, em torno do altar com a lareira e a estátua da divindade, na posição central, para onde se direciona o culto. Creio que essa explicação seja anacrônica, pois já nos poemas homéricos há a demonstração da importância do centro por meio da imagem da

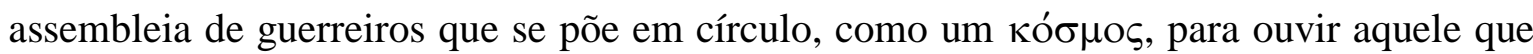
irá falar, posicionado no centro. Homero e Hesíodo preocuparam-se em deixar o mundo habitado na posição central, o que é depreendido de suas descrições do céu e do mundo subterrâneo como opostos simétricos. ${ }^{90}$

${ }^{90}$ Encontramos os relatos tradicionais sobre a origem e forma do universo nos poemas de Homero, em certa medida sistematizados por Hesíodo. Para Homero, o mundo consiste em um disco achatado, sobre o qual se sobrepõe o firmamento, que se supõe feito de metal, por causa de seu aspecto brilhante ("bronzeado", em grego $\sigma u ́ \delta \varepsilon \rho o v$, de onde, figurativamente, o espaço sideral - já tive a oportunidade de frisar a relação entre o firmus do firmamento e o radical *dhar-indoeuropeu). A parte mais alta do céu é envolvida pelas flamas do Éter, acima dos ares. O disco terrestre é contornado por um rio circular e infinito, Oceano, cujas águas desembocam em suas próprias nascentes. As raízes da Terra se fincam no Hades. Abaixo do Hades, há o Tártaro. Diferentemente de Homero, que apresenta um retrato final de uma concepção de mundo, Hesíodo estabelece uma história cósmica, sob a forma de uma cosmogonia, isto é, de uma sucessão de gerações, em

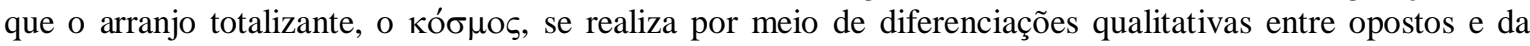

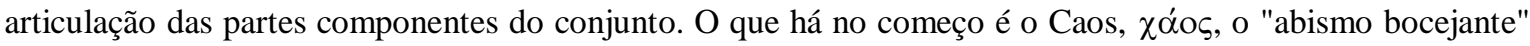
que permite a diferenciação entre Gaia e o Tártaro. Por partenogênese, Gaia forma Urano, o céu, a quem se une para originar o oceano circundante, a separar os continentes dos esteios do céu sólido, cujas partes superiores são preenchidas por éter, estando o interstício entre este e a superfície terrestre composto de névoa, formadora do ar e das nuvens. Abaixo do plano do solo, a Terra projeta raízes em direção ao Tártaro, que é literalmente um jarro, de onde brotam as raízes do mundo e todos os ventos, em uma mistura caótica. A vedação do colo do jarro por Zeus representa, nesta narrativa, a imposição de uma ordem coerente ao universo. Vernant aduz uma explicação de caráter psicanalítico para a figura do jarro, ao revelar a dupla utilidade desse utensílio entre os antepassados. Por um lado, os jarros eram enterrados nos celeiros com os frutos da terra, os quais inevitavelmente brotavam e atingiam a superfície. Por outro lado, também era costume o uso de jarros para o sepultamento. Portanto, as entranhas da terra são identificadas com o vaso enquanto símbolo do lugar do qual provém a vida e, concomitantemente, no qual habitam os mortos. Embora seja notável em ambos os poetas a preocupação em retratar um cosmo definido simetricamente, as primeiras menções a dimensões cósmicas quantitativas surgem apenas com Hesíodo, sob a forma de uma mensuração temporal: uma bigorna de bronze jogada do cimo do céu cairia por nove dias, até alcançar o solo no décimo. E daí até as profundezas do Tártaro, decorreria igual período de nove dias de queda, seguido do choque com as profundezas no décimo dia. Não se deve tomar essa indicação como uma medida dimensional precisa, porque esta fórmula quantitativa " $9+1$ " é recorrente em Homero, com sentido hiperbólico. Por nove anos os aqueus cercaram Troia, para tomá-la no décimo ano; por nove dias Apolo castiga os aqueus, até que Aquiles convoque uma reunião dos chefes militares no dia décimo; em diversas ocasiões - relatos de Sila e Caríbdis, dos lotófagos, da chegada à ilha de Calipso -, Odisseu e seus companheiros navegaram por nove dias para que se desse o evento de interesse no décimo dia; o mesmo Odisseu, tendo nove vezes liderado expedições militares, foi líder pela décima vez com a guerra de Troia. Portanto, o número nove deve ser compreendido como uma indicação de grandes quantidades ou de largo tempo decorrido previamente ao evento tratado. De tudo há duas características fundamentais das narrativas cósmicas míticas que devem ser enunciadas. Em primeiro lugar, o surgimento dos diversos elementos é explicado mediante sucessivas gerações, advindas da união entre grandezas preexistentes personificadas, atribuindo-se a origem dos diversos aspectos da realidade a um relacionamento sexual primordial. Em segundo lugar, o retrato mitológico do universo apresenta o 
De qualquer modo, o atributo da centralidade da lareira, que leva Anaximandro a assim denominar o eixo terrestre do cosmo, traz consigo enorme significância política e jurídica. A respeito disso, deve-se recorrer, mais uma vez, à esclarecedora narrativa de Heródoto. O historiador relata (História, 3, 142) os eventos subsequentes à morte de Polícrates, tirano de Samos: naquela ocasião, o sucessor escolhido por Polícrates, Maiândrio, fez erigir um altar em honra a Zeus Eleuthérios (libertador), e reuniu o povo em assembleia para anunciar que, embora lhe tenha sido confiado todo o poder e força de

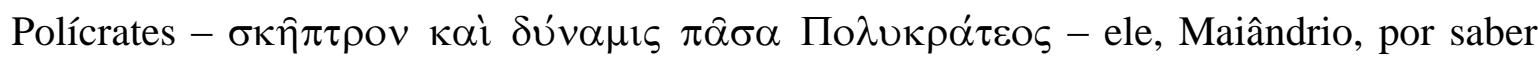
que não era com a aprovação de seus semelhantes que Polícrates exercera a tirania, resolveu depositar todo o poder no centro e proclamar com isso a isonomia. Tem-se aqui a clara confirmação da noção de que o exercício do poder está relacionado com a sua

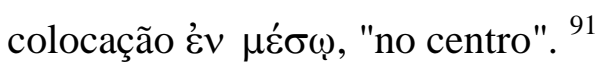

A presença de uma lareira no espaço público se deve à função contrastante por ela desempenhada, no sentido de oferecer uma antípoda em relação a todas as lareiras mantidas pelos particulares em suas residências. Ao situar-se no meio a lareira pública, e não qualquer das lareiras privadas, em relação às quais aquela se encontrava equidistante, dava-se a constituição e a própria expressão física da isonomia em vigor na $\pi$ ó $\lambda \mathrm{l}$ s. Desligada de qualquer das linhagens familiares, a lareira atua como um receptáculo do

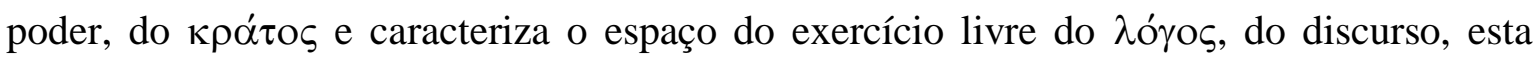
mesma prática que, segundo célebre interpretação etimológica de Heidegger, emerge paradoxalmente do âmbito privado, da atividade familiar de subsistência da colheita dos frutos da terra para se tornar o instrumento de exercício das relações políticas. O rearranjo arquitetônico da cidade expressa simbolicamente a gravitação dos espaços privados em torno do espaço público, que enseja para a vivência do direito a afirmação da isonomia e um movimento centrípeto, a crescente assunção das questões privadas pela $\pi$ ó $\lambda \iota \zeta$, por meio do vó $\mu \mathrm{o}$, da lei. ${ }^{92}$

Há que se ter em mente que o simbolismo da lareira privada remonta à antiga

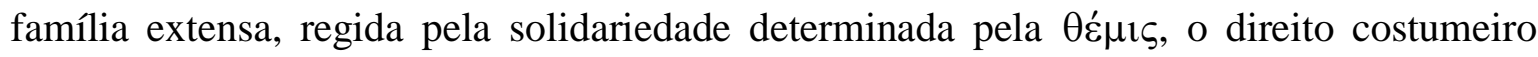

cosmo dividido em diversos níveis bem definidos e incomunicáveis entre si. Há o céu impenetrável, restrito aos deuses; em seguida, a terra, habitada pelos mortais; e o domínio obscuro subterrâneo. Não se trata ainda aqui das partilhas cósmicas dos $\delta \alpha \sigma \mu o$, analisados anteriormente, mas de divisões em planos estruturais do mundo, fisicamente apartados, incomunicáveis. Cabe ao poeta recorrer à divindade para poder oferecer uma visão holística do universo, que abarque todos os seus planos constituintes. Cf. HAHN, 169-176; KIRK et al., pp. 1-68; VERNANT, 243-258.

${ }^{91}$ VERNANT, p. 256.

92 PereirA M. H. R., vol. I, pp. 241-246; VERnANT, pp. 257-258. 
intrafamiliar anterior. A lareira doméstica é parte integrante do culto familiar, instituição que, segundo nos ensina Fustel de Coulanges, constituiu a forma originária de religião, muito antes da instituição do culto aos grandes deuses nacionais. Cada família tinha os seus próprios ritos a serem realizados perante seu fogo sagrado, cujo conteúdo era interdito aos que não pertencessem àquele núcleo familiar. A centralidade do culto ao fogo doméstico pode ser explicada, ainda segundo o historiador francês, pelo fato de que, em sua gênese, a chama seria acesa sobre o túmulo familiar, que se costumava situar na própria habitação. De acordo com as crenças então vigentes, os espíritos dos antepassados seguem vivendo junto aos corpos sepultados, transformadas em deuses subterrâneos que demandam, para sua alimentação, a realização de sacrifícios periódicos por parte de seus descendentes vivos, com o fim de que os espíritos ancestrais operem favoravelmente aos vivos. Separado do túmulo, o fogo manteve seu caráter sagrado, sendo-lhe oferecidos cantos e libações, ao mesmo tempo em que lhe eram dirigidas preces. ${ }^{93}$

O túmulo e o espaço doméstico governado pela lareira possuem naturezas semelhantes, no sentido de ambos serem espaços ocultos, fechados à luz em que se dão as atividades comunitárias, comerciais e políticas. A esfera privada, composta de lar e túmulo, é o espaço em que se operam os eventos da geração, do nascimento e da morte, relações misteriosas que devem permanecer alheias à imortalidade e notoriedade dos negócios preservados no espaço público. O único interesse público concernente à vida privada deve ser o de garantir a incomunicabilidade entre os diversos espaços privados entre si, e destes com a própria esfera pública, de modo que as leis cumprem a função de garantir a aparência dos limites do privado, delimitando-o, ocultando-o e evidenciando-o como o sinal de que o cidadão partilha de um lugar no mundo das coisas humanas, com um lar e a

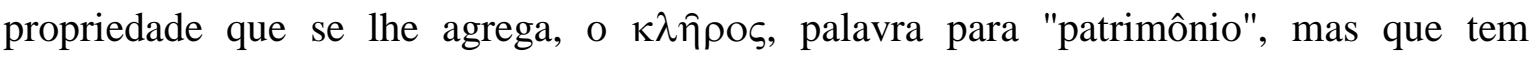
originalmente o sentido de "lote", "divisão". A lareira é a deusa Héstia, uma divindade doméstica que se encontra ao mesmo tempo associada e contraposta a Hermes, deus ligado aos espaços e atividades externos ao ambiente familiar. É característica do sexo feminino, em uma sociedade patriarcal e exogâmica, verdadeira mobilidade interfamiliar, embora única no curso da vida, consistente em deixar o lar paterno com o casamento para dirigir-se ao lar da família de seu marido, de sorte que a virgindade da deusa Héstia garante, por sua

\footnotetext{
93 Benveniste, vol. 1, p. 317; Fustel De Coulanges, Numa-Denis. A cidade antiga. $4^{\text {a }}$ ed. São Paulo: Edipro. 2009, pp. 17-37.
} 
consequente presença perpétua no lar, a coesão e a continuidade da família que lhe rende culto. ${ }^{94}$

A respeito disso, Vernant recorda o ponto de vista generalizado entre os gregos, expresso na tragédia da Electra de Sófocles, sobre a personagem Egisto, que é definido como um homem de natureza afeminada por causa de seu relacionamento com Clitemnestra, em função do qual passa ele próprio a habitar o palácio real de Micenas ao lado de sua cúmplice no assassinato do rei Agamêmnon. Tanto quanto em razão do adultério e do regicídio, o aspecto repulsivo desta relação reside na contrariedade ao ciclo natural determinado pelos vínculos familiares regidos por Héstia, em que à mulher cabe deixar a casa para seguir o marido, e não o contrário. ${ }^{95}$

O ideal expressado pelas legislações escritas é de moderação e conformação da cidade a uma concepção cósmica de ordem. Ao menos é o que se depreende da reflexão sobre os fragmentos de Sólon, responsável por dar início à legislação escrita entre os atenienses, por volta de 600 a. C. Dedicado não somente à $\tau \dot{\varepsilon} \chi v \eta \eta$ legislativa, mas também

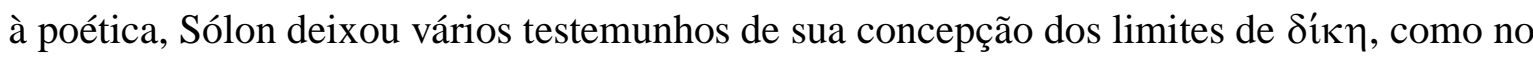
fragmento $36 \mathrm{~W}$, no qual o legislador-poeta afirma ter feito leis para o bom e para o mau,

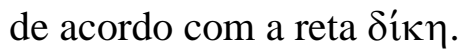

Hesíodo, no contexto de violentas lutas sociais, foi o primeiro a colocar o direito como um referencial comunitário, o que possivelmente se fez sentir nas lutas nas cidades jônias, anteriormente relatadas. Coube a Sólon desenvolver as ideias hesiódicas referentes à correlação entre o direito e a ordem divina do mundo, com a consequente crença no castigo decorrente de sua transgressão. No entanto, ao prenunciar tais questões no âmbito das discórdias entre os atenienses, Sólon se afasta do realismo cru de Hesíodo para fazer

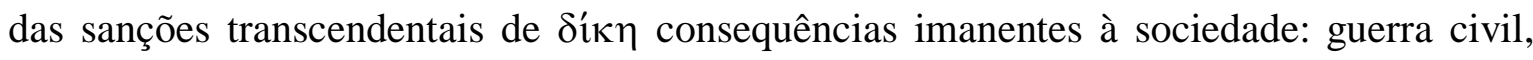
desordem, injustiça, miséria. Sólon realiza a primeira enunciação objetiva do nexo causal entre violação do direito e perturbação social, ao estabelecer a paz social como

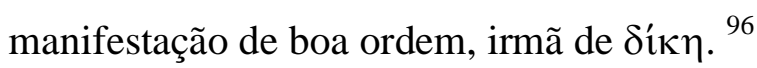

Sólon concebe uma legalidade intrínseca à vida política, uma causalidade social que se dá paralelamente à causalidade natural que Tales e Anaximandro começavam a

\footnotetext{
94 ARENDT, pp. 68-78; FuSTEl DE COULANGES, pp. 39-45; VERNANT, pp. 195-200, 207-212, 216-225.

95 VERNANT, pp. 200-207.

96 JAEGER, pp. 178-180.
} 
descobrir, na mesma época, para o devir eterno da natureza. O desenvolvimento da cidade obedece a normas regulares, o que Sólon deixa explícito em seu poema (fr. $10 \mathrm{~W}$ ), o qual diz que do domínio de homens poderosos sobrevém a ditadura, como das nuvens vêm a chuva e o granizo e ao raio se segue o trovão. Sem embargo, a ação humana individual na comunidade segue sujeita à imprevisibilidade. De qualquer modo, a injustiça só se mantém

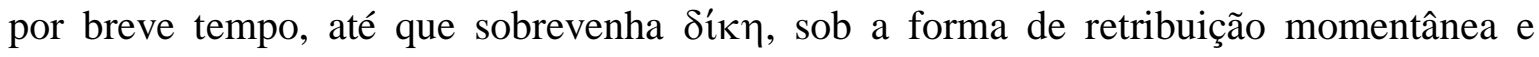
inesperada de Zeus, abatendo-se no presente ou sobre as gerações futuras. Sólon acreditava que, embora a riqueza aspirasse à própria ampliação, são os deuses que retiram o excesso de tesouros para reconduzir ao equilíbrio. Os poemas de retrospectiva de sua atividade política mostram a íntima conexão entre sua ação política e sua religiosidade: busca de um justo meio-termo entre abundância e pobreza, sem deixar que um dos partidos prevaleça. Sólon sabe que sua força reside unicamente em sua autoridade moral de pessoa reta e desinteressada entre os dois partidos. À massa basta obedecer à lei, mas aquele que estabelece as leis tem que ter uma alta medida, não escrita em nenhum lugar. Da íntima legalidade cósmica, o mais difícil, segundo Sólon, é a percepção inteligente da medida invisível que confere os limites a todas as coisas. ${ }^{97}$

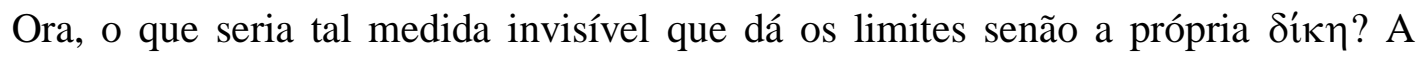
transição do período arcaico para o clássico da história grega traz consigo as marcas de todas as lutas políticas precedentes. Duas vertentes começam a operar para oferecer respostas à crise, atentas ao problema da centralidade do poder no espaço urbano. De um lado, reformadores sociais como Sólon e Clístenes, atentos à expansão da participação política demandada pela classe média crescente; de outro, os filósofos, como Pitágoras e Platão, ávidos de influir nos rumos da condução dos negócios públicos. De ambos os lados sobrevém o propósito de estabelecer leis para recriar o espaço da cidade.

${ }^{97}$ JAEGER, pp. 180-189. 


\title{
4. Os centros do cosmo: a ágora e a acrópole
}

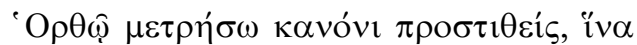

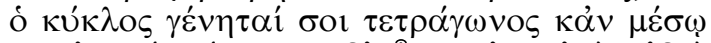

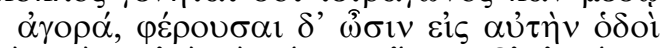

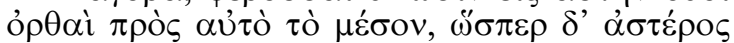

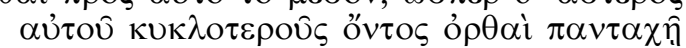 \\ $\dot{\alpha} \kappa \tau \hat{\imath} v \varepsilon \varsigma \dot{\alpha} \pi \mathrm{o} \lambda \alpha^{\prime} \mu \pi \omega \sigma v$. \\ $\ddot{\alpha} v \theta \rho \omega \pi \mathrm{\sigma} \varsigma \alpha \lambda \eta \hat{\varsigma}$. \\ - Medirei com reta régua estendida, de modo a \\ Gerar-te um círculo com quatro faces, em cujo meio \\ Haverá a praça; e ela apresentará caminhos \\ Retos, direcionados ao seu centro, como uma estrela que, \\ Sendo ela própria arredondada, em todas as direções retos \\ Raios propaga. \\ - Esse homem é um Tales!
} Aristófanes, As aves, vv. 1004-1009.

Embora a Ática tenha sido a última região a formular uma literatura própria, o que se deu justamente com os fragmentos de Sólon, houve plena conjugação de um forte sentimento comunitário e de Estado e a intimidade da esfera espiritual do indivíduo. Devese ao próprio Sólon, como informa Jaeger, tal capacidade de unir adequadamente o pensamento relativamente livre da Jônia, como uma força centrípeta, à força educadora implícita no ideal da nova ordem jurídica e de seu projeto político de liberdade. O forte senso de submissão às exigências da vida comunitária decorrentes desse amálgama teria condicionado o florescimento posterior da grande literatura política e histórica. Como se sabe, as leis de Sólon não buscaram suprimir o domínio aristocrático confirmado pela legislação draconiana, paradigma apenas alterado após a tirania dos Pisistrátidas, com as reformas de Clístenes. ${ }^{98}$

Como visto, o triunfo progressivo das novas forças sociais sobre a antiga classe

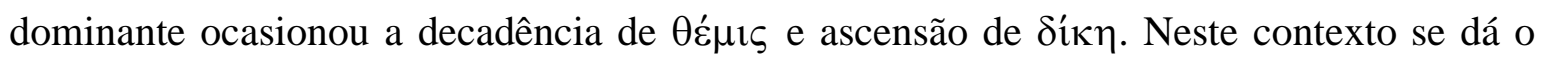

98 JAEGER, pp. 173-177. 
surgimento da filosofia e da legislação escrita como fenômenos concatenados com a racionalidade da $\tau \dot{\varepsilon} \chi \vee \eta$ arquitetônica.

Esses eventos são consequência direta dos movimentos populacionais que, no final da Idade das Trevas, acarretaram a desagregação da tribo e o início da propriedade privada,

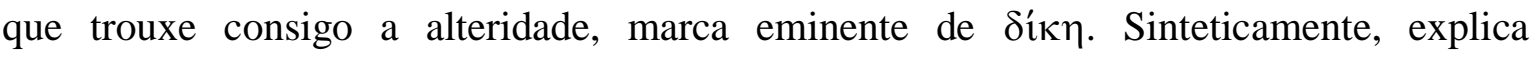
Benveniste ${ }^{99}$ :

L'époque ancienne est caractérisée par la grande famille où, en se mariant, tous les fils continuent à vivre, où ils élèvent leur famille propre, où parfois même les filles amènent leurs maris. A ce stade, il n'y a pas de propriété indistincte; il n'y a pas à proprement parler d'héritage, la grande famille restant propriétaire sans que cessent à aucun moment ses droits sur le bien. Puis cette grande famille s'est trouvée brisée. Pour des raisons économiques, les fils essaiment assez tôt. Les termes connotant cette "grande famille" deviennent d'un emploi de plus en plus rare; la notion même ne répond plus à la realité de l'institution; la grande famille se scinde en groupements plus étroits quand les descendants vont à leur tour fonder de nouveaux foyers.

A decadência do paradigma tribal ocasionou, ao seu tempo, a organização da sociedade de acordo com referenciais geográficos, e não mais familiares. Nesse sentido, prossegue o autor:

La seconde transformation est l'établissement des guerriers achéens dans la pólis ( $\left.\pi o^{\prime} \lambda \mathrm{s}\right)$, la ville commune. Cette évolution a lentement aboli les cadres sociaux antérieurs au profit de nouvelles divisions, celles-ci territoriales. Les anciennes divisions sociales, fondées sur la descendance généalogique, sont remplacées progressivement par les groupements que détermine l'habitat commun.

A instalação dos guerreiros na cidade, com a militarização das comunidades, é um evento que concorre para a conformação da vida política aos parâmetros estabelecidos pela

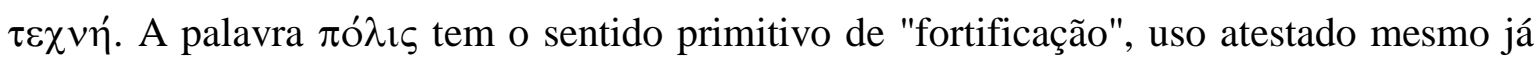
em tempos históricos, na prosa de Tucídides. Пó $\lambda ı \varsigma$ não designa simplesmente a cidade, e sim o "muro circundante", ideia que também origina a antiga palavra alemã Zaun e a

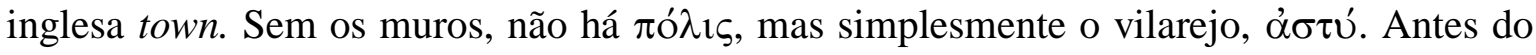
século VI a. C., época na qual se consolidou a transição ora tratada, a maior parte dos assentamentos gregos era desprovida de muralhas, embora fosse comum a existência de

${ }^{99}$ Benveniste, vol. 1, p. 309. 
uma cidadela elevada, a acrópole. Fortificação separada da área das habitações, dotada de templos e situada no alto de alguma colina que, em muitos casos, se tratava do local de algum antigo palácio micênico e refúgio para os habitantes; em outros tempos, serviria de baluarte para algum tirano local. O exemplo mais notável de uma cidade que, ao longo de toda a sua história de $\pi$ ó $\lambda \varsigma \varsigma$ independente, jamais foi dotada de muros é Esparta, por sinal, a mesma cidade que jamais aceitou que suas leis fossem escritas. ${ }^{100}$

Conforme se asseverou anteriormente, o crescimento e o subsequente enfraquecimento das tribos deram causa a uma profunda instabilidade da organização fundiária. Tal situação bem pode ter propiciado as condições para o surgimento de complexas regras sucessórias, que Benveniste afirma inexistirem na família extensa. A $\pi$ ódıৎ gradualmente estende sua autoridade sobre o domínio familiar. Sólon já havia elaborado normas sobre adoção. A herança está provavelmente ligada à estabilização da propriedade da terra, como permite supor o texto de uma lei da Lócrida, no século V a. C, reproduzida a seguir. Perceba-se a grave sanção prevista para aquele que apenas se atreva a aventar a alteração da divisão das terras. Entre uma e outra disposição, a invocação da autoridade do deus, aspecto anteriormente discutido ${ }^{101}$ :

\footnotetext{
Esta lei sobre propriedade de terras será válida para a divisão das terras de Hília e Liscária, tanto para as terras privadas quanto para as públicas. $O$ direito à terra caberá aos pais e ao filho; se não houver filho, caberá à filha; $e$ se não houver filha, ao irmão; e se não existir irmão, o proprietário será o parente mais próximo, de acordo com a lei; e se não houver parentes [...]. Tudo o que for plantado será protegido. Será amaldiçoado aquele que introduzir uma moção para divisão de terra ou votar a favor de tal moção no Conselho dos Antigos, na pólis ou no Conselho eleito, ou incitar a disputa civil pela divisão de terra; sua propriedade será confiscada e sua casa será demolida, de acordo com a lei sobre homicídio, a menos que, em caso de guerra, cento e um cidadãos da aristocracia ou a maioria decida trazer como colonos duzentos homens com idade e capacidade militares. Esta lei é dedicada a Apolo Pítio e aos outros deuses adorados no mesmo santuário. Aquele que transgredir essas cláusulas será amaldiçoado, ele e seus descendentes, e aquele que as respeitar será abençoado pelos deuses. Metade da terra pertencerá aos ocupantes anteriores, $e$ a outra metade, aos colonos. Os terrenos do vale devem ser divididos. As trocas serão válidas contanto que se façam diante de um magistrado. Se o demiourgoi obtiver mais lucro do que o permitido, tal lucro será consagrado a Apolo como uma oferenda por nove anos, e isso não será inscrito como lucro.
}

Considera-se da mesma época uma placa de bronze, que contém uma inscrição legal que se considera referente a Naupactus, uma colônia da mesma Lócrida. O texto

${ }^{100}$ ARENDT, p. 73, BENVENISTE, vol. 1, p. 367. RoBERTSON, p. 215-216.

${ }^{101}$ ARNAOUTOGLOU, p. 126. 
determina minuciosamente as normas e condições para a sucessão familiar na propriedade das pastagens e estabelece exceções e penalidades para a violação dessas regras, com menção a uma lei sobre homicídios anterior. Claramente, trata-se de uma comunidade antiga que se estende sobre uma nova área, determinando as novas divisões da terra. A lei

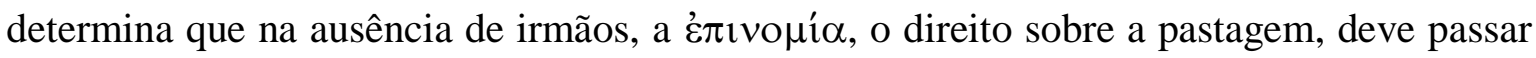

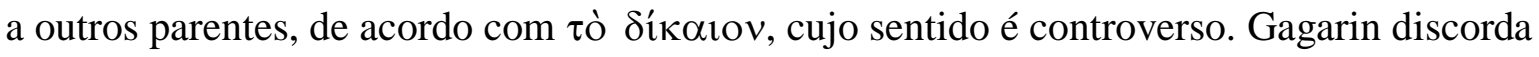
da ideia de que seja uma referência à lei, para afirmar que se trata de algo according to what is right or just. Contudo, conforme estudado anteriormente, a acepção ética da justiça

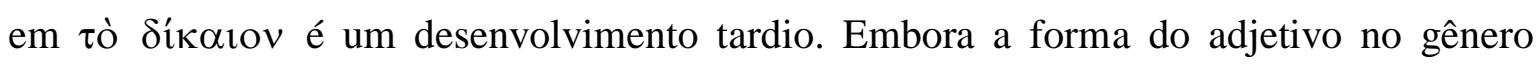
neutro corretamente sugira a Gagarin um sentido generalizante, descabido para mencionar

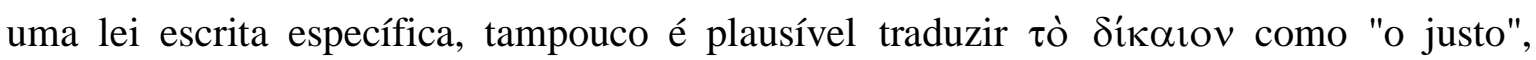
soando mais adequado interpretar a expressão à luz dos sentidos originais já analisados de

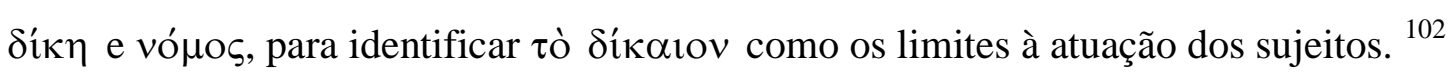

Os fatores enumerados por Benveniste - identidade determinada geograficamente e propriedade privada acompanhada da desvinculação da organização tribal fundada no sangue - são os fundamentos da reforma elaborada pelo legislador ateniense Clístenes, por volta dos mesmos anos em que as duas leis da Lócrida sobre propriedade foram elaboradas.

As reformas políticas implantadas por Clístenes em Atenas estiveram visivelmente apoiadas em alterações referentes à organização do espaço urbano. Tradicionalmente organizada segundo sua divisão em tribos ligadas por laços de parentesco religioso, a $\pi$ ó $\lambda 1 \varsigma$ doravante deverá abandonar tal agrupamento dos indivíduos por critérios gentílicos em favor do estabelecimento de um princípio territorial. Cada região da Ática passará a ser designada a cada uma das dez tribos, de modo que o pertencimento a uma tribo será determinado pelo solo, e não mais pela descendência.

Aristóteles (Política, 1275a, final) discute a imprecisão do critério de sangue para a determinação da cidadania, pois a adoção de tal parâmetro caracteriza o que conhecemos por trilema de Münchhausen: 1) o critério não se sustenta por si, uma vez que a regressão ad infinitum mostra que os primeiros habitantes da cidade não descendiam de cidadãos; o que denota fundamentar-se a qualificação para a cidadania em 2) parâmetros arbitrários; ou 3) na autoridade. ${ }^{103}$ Em resumo, há uma circularidade insolúvel em dizer que "cidadão é

\footnotetext{
102 GAGARIN, pp. 94-95.

103 O que, para efeitos práticos, dá no mesmo.
} 
aquele que é filho de outro cidadão". Apresentado o impasse, Aristóteles menciona as reformas de Clístenes, que tiveram por efeito a inclusão de muitos estrangeiros e exescravos no número dos cidadãos de Atenas. A despeito das dificuldades apontadas para a cidadania por descendência, Aristóteles não aprova de todo as determinações de Clístenes, uma vez que se questiona se todos os que obtiveram a cidadania nessas condições deveriam tê-la recebido, logo havendo dúvida sobre serem efetivamente cidadãos.

Com a determinação dos componentes de cada tribo em uma base geográfica, resta garantida a homogeneidade entre os integrantes da $\pi$ ó $\lambda ı \varsigma$, já que a identidade tribal deve corresponder tão somente à delimitação do território de cada tribo no mapa da Ática. A homogeneidade dos cidadãos é decorrente da homogeneidade do solo pátrio. Há apenas uma única porção de terra em destaque, que é o centro da cidade, reorganizado e remodelado para refletir não mais o centro religioso da vida comunitária, mas o centro político da representação política equânime, pois na ágora estão igualmente representadas

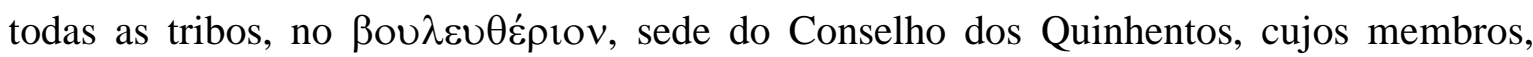
segundo critérios de revezamento entre todas as tribos, exercem a pritania, presidindo as sessões com o privilégio de se alojar no Lar comum, enquanto lhes couber a função. ${ }^{104}$

Ali está também a lareira, conforme já se pôde apontar. Lareira cujo simbolismo ora se encontra um tanto mais desvencilhado de suas origens relacionadas ao culto ctônico, embora retenha seu significado religioso - é importante que se assevere o fato de não se tratar de um movimento laico, conceito descabido nesse momento histórico. De qualquer forma, o simbolismo da lareira alcança patamares mais elevados de abstração, pois a partir

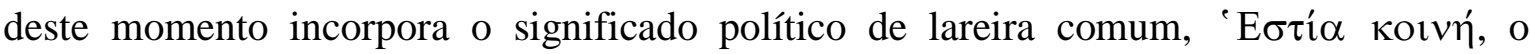
denominador comum, o equalizador de todas as casas que compõem a cidade, uma vez que não se identifica com nenhuma de suas respectivas lareiras familiares. A lareira, enquanto se transforma de centro do espaço religioso emocional e qualitativo em centro do espaço arbitrário e relacional, passa a figurar o princípio da igualdade cidadã.

Como dito, a transfiguração da lareira não é sintomática de um esforço de construção de um espaço público laico. Trata-se de um reordenamento de caráter crescentemente abstrato, sem dúvida, mas se deve ter em mente que a racionalidade, por si só, não configura um afastamento do plano religioso. O que se tem com as reformas de Clístenes é a possível fundação de uma religião política.

${ }^{104}$ VERNANT, pp. 288-290. 
Nesse sentido, Jean-Pierre Vernant ${ }^{105}$ :

\begin{abstract}
Se estamos com a Lareira comum, em um contexto ainda religioso, trata-se de uma nova forma de religião, de uma religião também política, e, no equilíbrio desses dois termos, é o último que pesa mais, com esse caráter "de racional e quase que de planificado" que os gregos cedo conferiram ao que se refere ao político. Toda magistratura, faz-se observar - e se tem razão em fazê-lo -, conserva um caráter religioso. Essa verdade tem sua contrapartida. Depois de Clístenes, certos sacerdócios, cuja importância não cessará de aumentar no curso dos séculos V e IV, são autênticas magistraturas. Fato significativo, e que os autores valorizam justamente: é a Clístenes que parece ligar-se a instituição do sacerdócio de tribos, sacerdócios anuais, escolhidos por sorteio na totalidade do corpo cívico, segundo o mesmo sistema de designação que as magistraturas com função propriamente política e, diríamos hoje, profana. Esses sacerdócios cívicos contrastam com os antigos sacerdócios gentílicos, privilégios de alguns gene, detentores de segredos religiosos e ligados aos cultos locais.
\end{abstract}

Ao promover a remodelação do espaço, Clístenes acabou dando causa, por via transversa, à reformulação da percepção do tempo na $\pi$ ó $\lambda$ ıs. Isto porque o calendário cívico, base para a alternância de poder entre as tribos ao longo do ano, deveria estar necessariamente seccionado em períodos iguais, correspondentes ao governo de cada uma das tribos. Deste modo, opôs-se ao calendário religioso, baseado em doze meses lunares, o calendário pritânico, dividido em dez pritanias. Como dez eram as tribos, e estas foram divididas em conformidade com o critério da partilha territorial, tem-se que a compreensão do tempo se fundamentou na prévia organização política do espaço. ${ }^{106}$

O número doze é muito caro à religião grega, sua importância não se resume à definição do número de divisões do calendário. Doze são os trabalhos de Héracles. Doze são também os deuses do panteão olímpico, bem como os titãs que os precederam. A organização do $\delta \hat{\mu} \mu \mathrm{o}$ em dez tribos por Clístenes tem o objetivo explícito de afastar o arranjo que vigorava anteriormente, em trítias, que se distribuíam em um total de doze grupos. Bem sabida a proveniência religiosa deste número, discute-se qual seria o critério de escolha do número dez em substituição, por parte de Clístenes. A razão mais provável se refere à disseminação, nesse período, do sistema de numeração dito herodiano, estruturada em uma contagem de base 10. A adoção desse novo sistema de numeração parece estar relacionada à difusão da moeda e às necessidades práticas do desenvolvimento da contabilidade escrita. Desnecessário repetir - pois muito já se frisou - o caráter

\footnotetext{
105 VERNANT, p. 289.

106 VERNANT, pp. 290-291.
} 
eminentemente político da escrita, introduzida nos negócios da cidade para o registro da lei no domínio público. ${ }^{107}$

A divisão da população da Ática em tribos definidas com base em parcelamentos homogêneos do território é um fator de reforço da nova ideologia isonômica, uma vez que a reorganização espacial acarreta a indistinção política entre áreas urbanas e rurais. Esse esforço pela neutralização da oposição entre o rural e o urbano vai claramente de encontro à situação vivenciada por ocasião da tirania de Pisístrato, que obteve apoio político junto à antiga aristocracia rural. O período compreendido entre o final do governo daquele tirano e a ascensão de Clístenes testemunhou o crescimento do $\delta \eta \hat{\mu o \zeta ~ u r b a n o, ~ c o m p o s t o ~ d e ~}$ artesãos e comerciantes, ao lado da nobreza citadina. Desta maneira, Clístenes deliberadamente se empenhou em erradicar a distinção campo-cidade como uma categoria significativa para a definição do lócus político individual. Apenas a pertença a uma das tribos arranjadas em derredor da ágora deveria ser tomada em consideração para a conferência do status da cidadania. ${ }^{108}$

Contudo, o ideal de homogeneidade provavelmente não figurou na ordem do dia para todos os reformadores políticos gregos. Tal parece ser o caso de Hipódamo, reconhecido como o primeiro a desenvolver o ideal do planejamento urbanístico, ao lado de ser o primeiro teórico da política, tendo concebido o espaço urbano com implicações totalmente opostas àquelas que animaram as reformas de Clístenes.

Com efeito, enquanto Clístenes imaginou uma repartição territorial que anulasse as diferenciações sociais entre os cidadãos da $\pi$ ó $\lambda \iota \varsigma$, Hipódamo sustentava a necessidade de se dividir o território em conformidade com a diferenciação por função entre os cidadãos. Como explica Aristóteles (Política, 1267b-1269a), a cidade de Hipódamo seria composta por dez mil cidadãos divididos em três grupos: artesãos, lavradores e guerreiros. Por sua vez, a terra seria dividida também em três porções, conforme fosse destinada ao desempenho do culto, ao sustento dos guerreiros ou à propriedade dos camponeses. Também as leis seguiriam a divisão tripartite, ao versarem sobre insulto, injúria e homicídio, que Hipódamo teria considerado como as três matérias que originavam casos judiciais.

${ }^{107}$ Eves, Howard. Introdução à história da matemática. $5^{\mathrm{a}}$ ed. Campinas: Unicamp. 2011, p. 32; VeRNANT, pp. 291-292.

${ }^{108}$ VERNANT, pp. 292-294. 
O advento da $\pi$ ó̉ıৎ na Jônia se volta para a realização da ordem política que se traduz na simetria urbana, justificada por meio do recurso a uma ordem cósmica recentemente descoberta pelos primeiros filósofos. A concepção cosmológica é caracterizada por seu funcionamento relacional, que põe os componentes do mundo em situação de equivalência e equilíbrio. Por sua vez, a configuração urbana apresentada por Hipódamo coloca o desenho da cidade em função direta de uma concepção do universo em termos de proporção, de uma harmonia que perfar-se-á no momento em que cada componente do cosmo estiver situado em seu devido nicho. ${ }^{109}$

Não se pode perder de vista o fato de que, além de teórico político e primeiro urbanista, Hipódamo era tido pelos antigos como um $\mu \varepsilon \tau \rho o ́ \lambda o \gamma o \varsigma$, alguém dedicado ao estudo dos fenômenos celestes. Como aduz Rykwert, o traçado ortogonal do plano urbano não é uma criação de Hipódamo, mas um aspecto disseminado entre as cidades de inúmeras culturas em todo o mundo, sempre associado a uma específica concepção cosmológica de cada cultura. Méton de Colona é o único outro grego a que se atribuiu o qualificativo de urbanista, preocupado que estava em reformular a planta de Atenas segundo um plano circular, com ruas que irradiassem a partir do centro, o que lhe valeu ser ridicularizado por Aristófanes no trecho da comédia As aves que serve de epígrafe a este capítulo. Ao lado de ser teórico urbano, Méton era também um $\mu \varepsilon \tau \rho o ́ \lambda o \gamma o \varsigma$, como Hipódamo. ${ }^{110}$

Enquanto o modelo jônico busca efetivar uma ordem física racional mediante a mimetização da simetria espacial da ordem totalizante, a nova ideia de cidade apresentada pelo Hipódamo urbanista e teórico político pugna pela reafirmação de uma concepção conservadora, ligada a um modelo hierárquico de universo.

A ideia de que a $\pi$ ó $\lambda ı \varsigma$ deva se organizar em função de uma harmonia hierárquica não surge com as preocupações de Hipódamo. Não é outro o sentido do pensamento de Sólon, quando procura estabelecer, por meio de uma legislação que dá leis retas ao bom e ao mau, a boa ordem fundada na atribuição do correto lugar de cada um, de acordo com

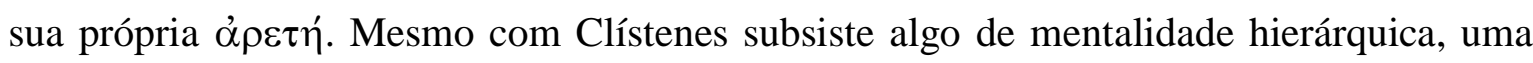
vez que o reformador não aboliu os antigos critérios censitários, evidente elemento de

\footnotetext{
${ }^{109}$ VERNANT, pp. 299-300.

${ }^{110}$ RYKWERT, pp. 91-92.
} 
distinção por classes sociais. De qualquer modo, a manutenção desse sistema não aponta para a tendência que governou o esforço reestruturante de Clístenes. ${ }^{111}$

Aristóteles, na passagem há pouco indicada da Política, critica duramente o modelo proposto por Hipódamo, não sem antes caracterizar o urbanista como um excêntrico e afetado, ávido de distinção. Para o Estagirita, a participação das três classes no governo na cidade não tem condições de perdurar, uma vez que apenas os guerreiros dispõem de armas, inacessíveis aos lavradores e aos artesãos. Como a maioria das magistraturas deve ser preenchida por membros da classe armada, a participação das demais classes no governo se torna impraticável. Todos esses problemas enfraquecem o corpo político, pois comprometem a lealdade dos cidadãos, ao mesmo tempo em que tendem a reduzir as duas classes desarmadas à submissão em face da classe dos guerreiros.

Especificamente no tocante à divisão territorial proposta por Hipódamo, Aristóteles não vê sentido na atribuição da propriedade aos lavradores, pois não está claro se esta classe é a responsável por cultivar as terras públicas, além das suas próprias. Se assim for, os lavradores, submetidos aos guerreiros, estarão sobrecarregados de trabalho, possivelmente não conseguindo produzir a quantidade de alimentos necessária para o sustento simultâneo de si e da classe militar. Se, ao contrário, forem os próprios guerreiros os responsáveis pelo cultivo da terra destinada ao seu sustento, então esta classe em nada se distinguirá daquela dos lavradores. Finalmente, se a responsabilidade pelo cultivo couber a uma quarta classe, ter-se-á um grupo desprovido de qualquer participação política.

Vernant e Benveniste, autores em que se fundamenta muito do que se diz neste trabalho, são avatares do estruturalismo francês. Em sua análise do modelo urbano concebido por Hipódamo, Vernant alude à teoria estruturalista da tripartição de funções, enunciada por estudiosos como Georges Dumézil e Émile Senart. Segundo essa teoria, haurida das pesquisas de mitologia comparada, as diversas religiões elaboradas pelos indoeuropeus estão organizadas a partir de tríades que expressam a ideologia das três funções, ou seja, um quadro no qual cada elemento ou divindade componente da tríade aludiria a uma das três funções elementares da sociedade humana organizada: a soberania, com seus aspectos mágicos e jurídicos; a guerra, com seus atributos de coragem e força física; e a vida agrícola, responsável pela subsistência e organização econômica da sociedade como um todo. Todo fato cultural é considerado como resultante da atividade dos homens do

${ }^{111}$ VERNANT, pp. 301-302. 
tempo, de modo que as três divindades refletiriam - e legitimariam, acrescento - as atividades das classes sociais dos aristocratas, dos guerreiros e dos agricultores-pastores. Vernant vê indícios da ideologia das três funções na divisão do território com fundamento nas ocupações sociais proposta por Hipódamo, entendimento que poderia ser facilmente estendido até o plano urbano pensado por Platão, como será visto adiante (Benveniste menciona o Críton de Platão em sua apresentação do tema). ${ }^{112}$

Suspeita-se que as ideias de Hipódamo tenham origem diretamente no pitagorismo, uma vez que esta doutrina notadamente havia dado ênfase à ideia de harmonia, definida por razões numéricas, que se sabe ter sido posteriormente estendida pelos seguidores de Pitágoras à seara política, no âmbito dos regimes estabelecidos pela seita na Magna Grécia.

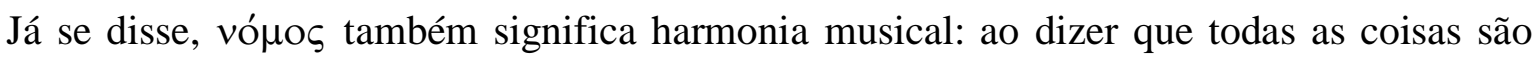
números, os seguidores de Pitágoras queriam expressar uma figuração espacial, determinada matematicamente mediante o recurso à noção de harmonia, obtida do campo da música e daí extrapolada para uma explicação do universo. ${ }^{113}$

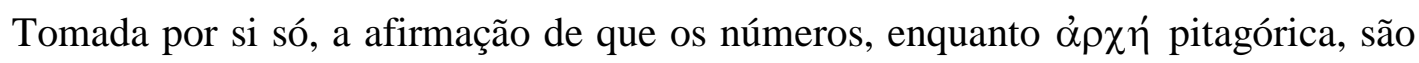
entes corpóreos pode conduzir a equívocos, pois isto não significa dizer que os números existem por si, idealmente, mas que todos os objetos são desdobramentos espaciais do número quatro, pois o um é a unidade; com o dois, define-se a linha; três pontos dão a área; e quatro, o volume. ${ }^{114}$

Daí a figura sagrada formada por esses conjuntos de pontos receber o nome de $\tau \varepsilon \tau \rho \alpha \kappa \tau u ́ \varsigma$, conforme representado a seguir:

Há quem tenha visto nesta figura sagrada pitagórica o fundamento da opção constitucional de Clístenes pelo número de dez tribos. Contudo, em conformidade com o

\footnotetext{
${ }^{112}$ DuMÉZIL, Georges. Mythe et épopée I. II. III. $1^{\text {ère }}$. éd. Paris: Gallimard. 1995, pp. 39-57; BENVENISTE, vol. 1, pp. 279-292; LePARGNEUR, Hubert. Introdução aos estruturalismos. S. ed. São Paulo: Herder. 1972, pp. 105-111; VERNANT, p. 306.

${ }^{113}$ VERNANT, pp. 302-303

114 Copleston, p. 47.
} 
que se expôs mais acima, tal escolha está relacionada a outras questões. As ideias pitagóricas, por terem entre suas consequências o estabelecimento de paradigmas cósmicos hierárquicos, guardam muito mais afinidade com as concepções políticas de Hipódamo do que com os esforços neutralizantes de Clístenes. Tendo sido o responsável pelo planejamento da colônia de Turi, na Magna Grécia, é muito provável que Hipódamo tenha estado em contato com o ambiente intelectual do pitagorismo.

Os pares de contrários, comuns entre outros filósofos pré-socráticos, que explicam a estabilidade cósmica a partir da constante superação antinômica de um pelo outro, em perfeita polarização, são dispostos hierarquicamente pela doutrina pitagórica, com a disposição das qualidades do limitado e do ilimitado. A saúde, por exemplo, não é mais simplesmente o oposto da doença, mas também lhe é qualitativamente superior. A relação cósmica definida pela harmonia defendida pelos pitagóricos era, portanto, qualitativa, hierárquica. ${ }^{115}$

Em verdade, há autores, como Kirk-Raven-Schofield e Copleston, que indicam que a real importância da escola de Pitágoras se funda muito mais na extensão de sua influência do que nas inovações filosóficas de sua doutrina, pouco agradável a uma perspectiva positivista da história da filosofia, em razão de seu reavivamento das doutrinas de Orfeu. ${ }^{116}$

Como se sabe, o movimento pitagórico é notável pelo grau de engajamento político de seus integrantes, tradicionalmente se contando, entre os discípulos de Pitágoras, considerável número de legisladores. Tal fato, no entanto, apenas passou a receber a devida atenção em tempos recentes. A crítica tradicional optou por seguir Zeller, que se funda em Aristóteles para denegar ao pitagorismo o valor de movimento político. Tal foi a orientação que informou inclusive a seleção dos fragmentos por Diels-Kranz, que claramente põem em relevo os aspectos relativos à doutrina dos números, em detrimento dos ensinamentos éticos da escola. ${ }^{117}$

Hodiernamente é realçada, contudo, a existência de duas categorias de praticantes da doutrina de Pitágoras: os mathematici, que se dedicaram à especulação sobre a música e

\footnotetext{
115 COPLESTON, pp. 48-49; KIRK et al., pp. 242-245.

${ }^{116}$ Copleston, p. 50; KIRK et al., p. 248.

${ }^{117}$ CoRNELli, Gabriele. Refundar a cidade: do projeto filosófico-político das cidades pitagóricas à utopia projetual da República de Platão. In: XAVIER, Dennys Garcia. CoRnelli, Gabriele (orgs.). A República de Platão: outros olhares. s. n. São Paulo: Loyola. 2011, p. 156; GAGARIN, p. 125.
} 
o número; e os acusmatici, em geral homens mais velhos, ocupados com a política, e que adotaram os preceitos éticos da escola como estilo de vida. Tais preceitos eram enunciados

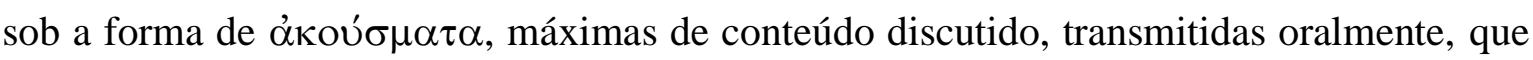
provavelmente se tornaram objeto de memorização - como um "catecismo" - e que, dado seu caráter sigiloso, podem ter servido ainda como senha para o reconhecimento mútuo dos membros da seita. ${ }^{118}$

Com efeito, muito da atividade de Pitágoras relatada pelas fontes antigas consistia em atividades exortativas. Consta que, ao chegar a Crotona vindo de Samos, de onde teria saído por ocasião da tirania de Polícrates - o mesmo a quem sucederia Maiândrio, com seu importante discurso sobre a centralidade física do poder político - Pitágoras se dedicou de início à pregação de seus preceitos éticos entre os variados segmentos da sociedade local (homens, mulheres, crianças e jovens). Seus discursos teriam logrado, sempre segundo as fontes antigas, arrebatar grande quantidade de seguidores para a sua doutrina, os quais passariam a constituir verdadeira comunidade política. ${ }^{119}$

Essa comunidade política pitagórica se assentava em dois pilares: a convivência comum naquilo que se chamava a casa dos ouvintes, onde se escutava as exortações do mestre; e a propriedade comum de todos os bens, compartilhados entre os membros do grupo. Tais caracteres davam aos pitagóricos a conformação de uma verdadeira koıvoví $\alpha$, de uma comunidade. Com o crescente número de adeptos e a consequente ampliação exponencial de seu poder, é sabido que a comunidade passou a controlar não apenas uma $\pi$ ódıৎ, mas toda uma região no sul da Península Itálica, ora sujeita às inovações políticas dos pitagóricos.

É natural que tamanha expansão, ao promover inovações que se traduziam em reformismo político e colonização jurídica de um vasto território, tenha dado causa a esforços de oposição em vários lugares, que acabaram por conseguir restringir cada vez mais a área sob domínio dos pitagóricos. Ao tempo do declínio, Árquitas de Tarento surge como o último herdeiro das ambições políticas da seita. Eis o contexto de sua tentativa de articulação com Dioniso de Siracusa, intermediada pela atuação diplomática de uma personagem improvável aos olhos modernos: Platão.

\footnotetext{
${ }^{118}$ KIRK et al., pp. 239-241, 244.

${ }^{119}$ KIRK et al., pp. 232-239.
} 
A despeito da já assinalada impossibilidade de se imputar genealogia pitagórica às reformas de Clístenes, tal como traçada anteriormente para Hipódamo, é importante que se estabeleça nuanças no contraste feito entre essas duas personagens, uma vez que as motivações de um e outro são idênticas, embora diversos os métodos. Clístenes e Hipódamo estão ambos preocupados, como Sólon estivera antes deles, com a condução adequada dos conflitos sociais, que já haviam propiciado a reorganização da $\pi$ ó $\lambda ı \varsigma$ na Jônia, como visto em capítulo precedente. ${ }^{120}$

Vernant, mais uma vez ${ }^{121}$ :

No contexto histórico já modificado, as preocupações de Hipódamo não deixam de ser bastante próximas [às de Clístenes]. A isonomía de tipo clisteniano não conseguiu suprimir os antagonismos sociais. Muitas cidades do século $V$, e mais ainda do século IV, estão divididas por lutas intestinas, em que as considerações de interesses - o que nós denominaríamos o econômico - tomaram uma importância que elas não tinham na época de Clístenes. Essas contradições não cessarão de se agravar, e Platão poderá denunciar, por trás da aparente unidade do Estado democrático, o combate dos ricos e dos pobres, dispostos em dois campos inimigos. No espírito de seus partidários, as teorias das classes funcionais - que parecem retomar a tradição indo-européia relativa à organização tripartida da sociedade - visam institucionalizar a diferenciação das classes sociais apenas para assegurar melhor a unidade e a homogeneidade completas do Estado. Aliás, a solução de Hipódamo distingue no corpo social três classes que permanecem fechadas em sua função própria: guerreira, artesanal, agrícola; divide o território em três setores: domínio sagrado, reservado aos deuses; público, reservado aos guerreiros; privado, atribuído aos agricultores. Mas todas as classes acham-se unidas e igualadas no plano propriamente político: elas compõem conjuntamente um só e mesmo dêmos que elege seus magistrados. O sistema hipodâmico, se implica uma imagem diferenciada da sociedade humana, não institui hierarquia na esfera política no sentido próprio. Hipódamo distingue e classifica os diversos tipos de atividades que são necessárias à vida do grupo, e que entretanto permanecem exteriores ao político compreendido como o exercício em comum do poder de comandar. $O$ que é novo nele e que constitui a peça magistral de seu sistema é a especialização da função militar, confiada a uma classe de guerreiros profissionais. Ora, a função guerreira, ao contrário das atividades artesanais e agrícolas, ressalta aos olhos dos gregos como sendo do domínio público; concerne à comunidade em seu conjunto; é integrada ao político. É nesse sentido que há, apesar de tudo, uma certa disparidade no status das três classes sociais. Por que essa situação particular dos guerreiros na pólis? Para Hipódamo, ao isolar a função militar, por sua natureza próxima do político, tratava-se de purificar de todo contato com a vida econômica, com essa esfera de interesses privados que agora aparece como um fator de divisão e de oposição entre os cidadãos. Os militares não têm propriedade pessoal. Como em Esparta, são sustentados pelo Estado com a terra comum. Uma vez que sua especialidade, como classe funcional, consiste em encarregar-se de um setor que pertence ao domínio comum ou público, não podem possuir nada de particular; sua atividade social não deve revestir-se de nenhum caráter privado.

\footnotetext{
${ }^{120}$ VERNANT, p. 303.
}

${ }^{121}$ VERNANT, 305-307. 
Não é possível pensar uma proposta urbanística como a de Hipódamo, com suas implicações no seio da doutrina política pitagórica, sem que venha à mente o modelo da cidade platônica. A $\pi$ o $\lambda \imath \tau \varepsilon i ́ \alpha$ anunciada por Platão se assenta sobre os mesmos fundamentos das comunidades conduzidas pelos discípulos de Pitágoras, a saber: a prática da escuta e o compartilhamento de bens. Por outro lado, como indica Vernant, o modelo platônico converge com o plano de Hipódamo no que se refere à especialização da função militar, cujos membros são consequentemente desprovidos de lugar na esfera privada.

No trecho, Vernant assevera ainda que Platão se mostrou sensível ao mesmo problema que motivara Clístenes e Hipódamo, qual seja a implantação das condições para a existência de uma comunidade isonômica. Seu objetivo final é a constituição de um Estado que seja verdadeiramente uno e homogêneo. Tal ideal de homogeneidade adquire contornos imagéticos com o mito platônico dos metais, no qual cada classe é comparada a um metal, de modo que a miscigenação das melhores classes só pode acarretar a decadência da linhagem, assim como a mistura dos metais mais preciosos invariavelmente resulta em uma liga inferior. Enquanto Hipódamo buscava igualdade política por meio da hierarquia social, Platão necessariamente conjugava a igualdade política com a igualdade de condições na vida social. Quando Clístenes baralhou todas as classes e famílias em tribos dispostas territorialmente, Platão tratou de estabelecer a mais absoluta clivagem entre os grupos. ${ }^{122}$

À luz de passagens da Carta Sétima, tais como 336c-337c e 351a-351d, nas quais Platão expõe sua posição acerca das práticas da instrumentalização do governo da cidade em favor de interesses privados (ou em desfavor de interesses privados de outros grupos, o que provavelmente tem o mesmo significado) como causadoras dos males que levaram à morte de Dion e à desorganização política da Sicília, tem-se a demanda de uma depuração sistemática da atividade política que excluísse todos os que não se dedicassem integralmente à vida pública.

Em 337b e s., Platão chega a colocar critérios para a seleção dos homens a serem encarregados da feitura das leis: pais de família; de certa idade; oriundos de uma ancestralidade de boa reputação; e dotados de suficiente propriedade. Estes deveriam ser atraídos, mediante a oferta de honrarias, para fora do âmbito privado, a fim de se 
dedicarem de maneira imparcial à elaboração de leis. Os membros dessa classe seriam em número de cinquenta, o que Platão julga suficiente para uma cidade formada por dez mil chefes de família.

A segmentação de uma classe política deve ser entendida como uma condição sem a qual é impossível a implantação exitosa de qualquer esforço reformador de inspiração clisteniana, de clara intenção homogeneizante. Platão provavelmente diria que o erro de Clístenes esteve em fazer da homogeneidade dos cidadãos um meio, e não a efetiva finalidade da reforma. Mas, ao colocar entre a esfera privada e a pública um muro que se torna uma barreira intransponível em vez de simplesmente ocultar uma da outra, Platão implode a possibilidade de participação política ampliada.

Para Platão, portanto, há que se transformar a política em uma atividade especializada - uma profissão. Paradoxalmente, a política como profissão é também uma contraprofissão, na medida em que se volta integralmente à esfera pública, ao contrário de todas as demais profissões, devotadas ao privado.

A organização física do espaço urbano preconizada por Platão guarda importantes divergências em relação ao modelo de Clístenes. Platão tratará dessas questões de maneira mais detida nas Leis, texto em que o filósofo apresenta um esquema de organização política que, diferentemente do que se observa na República, leva em conta as imperfeições humanas. É de se ressaltar o fato de que a cidade ora apresentada por Platão não tem em seu centro a ágora, mas a acrópole. Esta é uma inovação importante porque a acrópole não é um lugar dedicado à atividade política, como o é por excelência a ágora. A acrópole é destinada aos deuses, ao culto. A evidente consagração da cidade às divindades é confirmada pelo retorno à divisão da população em doze tribos, dedicadas cada qual a uma divindade. Consequentemente, observa-se a restauração da divisão do espaço entre as doze tribos, bem como do ano em doze meses. ${ }^{123}$

É significativo que o rearranjo espacial concebido por Platão denote os aspectos reacionários de sua proposta. A comunidade ateniense caminhava em sentido oposto ao de seu pensamento: à evidência do caráter simbólico da lei escrita, literalmente um monumento à autoridade suprema da $\pi$ ó $\lambda \iota \varsigma$, conforme discutido anteriormente, é notável que a decisão que marca o ponto de inflexão para a consolidação da democracia ateniense

${ }^{123}$ VERNANT, pp. 307-309. 
tenha sido a transferência das leis de Sólon, então mantidas na Acrópole - lugar sagrado, de onde governavam os homens como deuses - para a Ágora, onde serviriam, como os demais monumentos ali localizados, de garantes da liberdade e igualdade democráticas. Tal medida tem o caráter simbólico de afirmação da ordem política democrática, tal como se deu com o patrocínio pela $\pi$ ó $\lambda \iota \varsigma$ dos festivais públicos, encenações cívicas e obras de arte com motivos históricos (referentes à queda dos tiranos e às guerras médicas). ${ }^{124}$

Senhores do espaço e do tempo, os deuses regem a cidade, posicionados દ́v $\mu \varepsilon \dot{\varepsilon} \sigma \omega$, no centro, na acrópole, onde doravante estará localizada também a deusa Héstia, a lareira comum, historicamente posicionada na ágora. Se a democracia ateniense retirou as leis de Sólon da acrópole e as colocou na ágora, Platão desloca o fogo público sagrado da ágora para a acrópole.

A concepção platônica, tal como a clisteniana, busca organizar as porções do território de cada tribo de forma circular em relação ao centro. Havia, porém, a dificuldade de se dispor adequadamente os lotes das 5040 famílias de maneira equidistante em torno do centro. Muitos lotes ficariam necessariamente longe do centro urbano e próximos à fronteira, para não mencionar o fato de que muitos estariam inteiramente situados na área rural.

A solução apresentada por Platão para esse problema é engenhosa. Consiste em dividir cada lote em dois meios-lotes, dos quais um ficaria situado nas proximidades da acrópole, enquanto o outro estaria localizado à mesma distância com relação à fronteira. Dessa forma, os primeiros lotes teriam uma metade contígua ao centro e a outra contígua à fronteira; um segundo grupo de lotes teria um meio-lote fazendo divisa com as terras mais próximas à acrópole, e o outro meio-lote divisando com os terrenos junto à fronteira; e assim sucessivamente, de modo que os últimos lotes entregues seriam equidistantes em relação ao centro e às bordas do território. No conjunto, todos os lotes apresentam idêntica distância média para os mesmos referenciais espaciais. ${ }^{125}$

Como consequência desse projeto, cada cidadão seria proprietário de uma área urbana e de outra rural, o que anularia a distinção entre citadinos e camponeses. O gênio de Platão logra criar um modelo de cidade que promove a homogeneidade pretendida por

\footnotetext{
${ }^{124}$ HÖLKESKAMP, Karl-Joachim. (In-)Schrift und Monument. Zum Begriff des Gesetzes im archaischen und klassischen Griechenland. In: Zeitschrift für Papyrologie und Epigraphik, Bd. 132 (2000), pp. 73-96, disponível em http://jstor.org/stable/20190691 (Acessado em 09/11/2011 11:17), pp. 92-96.

${ }^{125}$ VERNANT, 308-309.
} 
Clístenes entre o urbano e o rústico, ao mesmo tempo em que, apesar de motivado pela valorização da religiosidade tradicional, consagra no pensamento ático o ideal jônico do plano simétrico da $\pi$ ódıs.

Aristóteles, no segundo livro da Política (1265b) critica a divisão dos lotes proposta nas Leis, por duas razões: primeiramente, por discordar da interdição platônica da ampliação da propriedade da terra, o que considera incoerente com a permissão de aumento em até cinco vezes das demais formas de riqueza e propriedade; ademais, Aristóteles duvida que a divisão em meios-lotes seja capaz de propiciar a boa condução da vida doméstica, pois a família se verá obrigada a conduzir suas atividades com dificuldade, em dois lugares separados, concomitantemente.

Já se disse, Platão tem consciência de que sua proposta de organização da cidade constitui um modelo. Contudo, o fato de o filósofo ter considerado as imperfeições dos homens na concepção de seu projeto aponta claramente para a viabilidade do modelo. $\mathrm{O}$ que terá impedido a ação de Platão, no sentido de promover a concretização de sua proposta política?

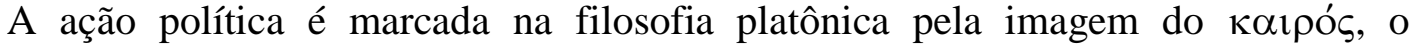
momento oportuno. A solução vislumbrada por Platão para salvar a política é entregar sua gestão a uma classe especializada, que não é outra senão a dos próprios filósofos. Esta seria a única maneira de assegurar que os responsáveis pela condução dos negócios públicos não se desviassem dos interesses da $\pi$ ó $\lambda ı$ c. O caráter idealista dessa proposta, como aponta Cornelli, não está na ingênua sinceridade com que se professa a retidão incorruptível dos filósofos e se propõe lhes entreguem o poder, mas no simples fato concreto de que praticamente não subsistem filósofos na cidade. Os poucos que restam são vistos com desconfiança pelo povo, ao mesmo tempo em que se mantêm como homens

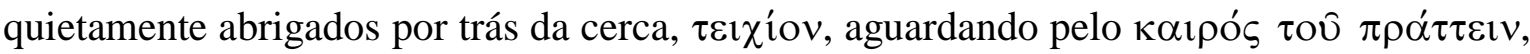
o melhor momento para agir. ${ }^{126}$

Essa cerca, literalmente um "murinho", é a própria Academia, em contraste com a cidade, representada por seu muro ( $\tau \varepsilon i ̂ \chi \varsigma)$. O filósofo se abriga nesse espaço para pensar a cidade, enquanto lhe é impossível agir. Como seu pensamento tem em vista sempre o problema da política, o espaço de reflexão da Academia está em contínuo processo de

${ }^{126}$ CORNELLI, p. 153. 
comunicação com a vida extramuros, nunca se colocando como uma forma de escape ou em substituição à vida política. Atrás da cerca, há o jardim, lugar adequado para a

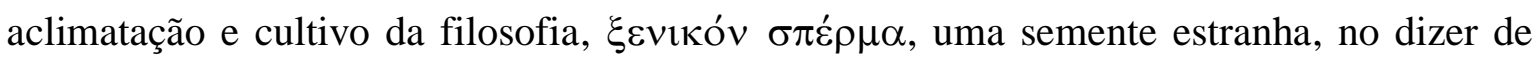
Sócrates, para a qual o solo de Atenas tem se mostrado pouco fecundo. ${ }^{127}$

Sócrates, ao levar sua missão filosófica às últimas consequências, afirma que, houvesse tido a oportunidade em alguma outra cidade mais adequada, teria tido sucesso em sua atividade filosófica e, junto com a própria vida, teria salvado o bem comum. Diante de tal constatação, mostra-se equivocado supor que o modelo platônico constitua uma utopia da evasão. Ao contrário, no dizer de Cornelli, trata-se de uma utopia projetual de reconstrução, que se pretende seriamente uma alternativa ao estado de coisas vigente. Deve ser encarada, portanto, como uma proposta idônea de reformulação espacial da $\pi$ ó $\lambda ı \varsigma$. 128

A expectativa de plausibilidade do projeto político de Platão é nutrida pelo antecedente bem sucedido da experiência dos pitagóricos no sul da Itália, conforme anteriormente explorado. Segue Cornelli, para afirmar que o pitagorismo havia inaugurado a expressão de uma concepção itálica da política, de nova forma de relacionamento entre o poder e o saber, na qual a escola de pensamento não mais se limitaria a enunciar uma doutrina, mas passaria a consagrá-la como uma forma de organização e de agir concretos, enfeixando doutrina filosófica e poder político. ${ }^{129}$

A confusão entre saber e poder é uma diretriz fundamental herdada pelo projeto platônico para a cidade. O Sócrates platônico valoriza as artes da legislação e da construção como as atividades que verdadeiramente se deveria chamar de políticas, porque são as únicas que fornecem algum grau de confiabilidade, já que desempenhadas com o saber de um artesão. Com isso, Platão visa combater o paradigma da ação política ilimitada e imprevisível, desprovida de sentido porque centrada no discurso, e não no conhecimento. 130

Árquitas de Tarento seria, nesse contexto e em sua época, o epígono do poder pitagórico na península. O relato de Platão (Carta Sétima, 338c-339e) permite supor que o desdobramento de maior significância para as ambições políticas do tarentino fora o

${ }^{127}$ CORNELLI, p. 154.

${ }^{128}$ CORNELLI, pp. 153-154.

${ }^{129}$ CORNELLI, pp. 156-158.

${ }^{130}$ ARENDT, pp. 208-209. 
estabelecimento da relação de $\varphi \imath \lambda i ́ \alpha$ com Dionísio de Siracusa, mantida a instâncias da ação intermediadora do próprio Platão, que àquela altura já agia mais por conta da insistência de Árquitas do que com base em qualquer esperança na suposta conversão do tirano siciliano ao estudo da filosofia.

No entanto, se a presença de Platão junto à corte de Siracusa era necessária para a persecução dos propósitos políticos de Árquitas, o convencimento de Dionísio era preciso para a concretização das intenções políticas específicas de Platão. O filósofo ateniense pretendeu, mediante sua ação exortativa de aconselhamento, submeter toda a Sicília ao governo impessoal das leis em lugar do mando dos tiranos (Carta Sétima, 334c-334d), ignorantes do Bem e da Justiça divinos e humanos, praticantes de um domínio que escraviza e que se prova ruim para dominadores e dominados.

Hans Kelsen, em seu exercício psicanalítico sobre Platão, não deixa de situar o projeto platônico no âmbito dos ideais, apresentando a $\varphi \imath \lambda i ́ \alpha$ que uniu o filósofo a Dion de Siracusa como a grande motivação para o que vê como uma participação aventureira e ingênua nos eventos da Magna Grécia. Para Kelsen, a dedicação de Platão à filosofia por toda a vida se deve ao fato de este nunca ter vislumbrado o momento oportuno para a ação política. ${ }^{131}$

De qualquer modo, é interessante ressaltar a convergência que se dá entre as figuras de Pitágoras e Platão, no sentido de que ambos partilham de um projeto político fundado nas mesmas práticas doutrinadoras e no mesmo regime de propriedade; um projeto animado pelo intuito de superação de uma situação de opressão tirânica, a fim de propiciar a instituição do modo de vida filosófico. Pitágoras foge do jugo de Polícrates para fundar a Magna Grécia como entidade política única, moldando-a conforme sua doutrina. Platão se encontra em uma Atenas hostil aos filósofos, de onde pretende pelo menos se evadir, a fim de estabelecer alhures - possivelmente na mesma Magna Grécia - o governo filosófico preconizado por sua utopia séria.

Portanto, a conclusão paradoxal a que conduz o acompanhamento do contexto político em que se dá o projeto da cidade platônica é que este se despe de seu rótulo idealista para assumir os contornos de verdadeira realpolitik, que se põe como uma via possível, amadurecida mediante o conhecimento dos erros e acertos dos esforços daqueles

${ }^{131}$ Kelsen, Hans. A ilusão da justiça. $4^{\text {a }}$ ed. São Paulo: Martins Fontes. 2008, pp. 152-154, 171-175. 
que o precederam (os pitagóricos e Sócrates), bem como do próprio tatear diplomático no presente. A utopia platônica não é um exercício estéril de imaginação, mas uma atividade séria, a que se deve dedicar uma vida inteira para o adequado desempenho, como Platão faz exclamar Glauco na República. As ideias de Platão sobre a conformação da $\pi$ o $\lambda \iota \tau \varepsilon i ́ \alpha$ - e com isso, de seu próprio plano urbanístico, de sua disposição física - merecem ser contadas entre as propostas políticas, juntamente com a disposição simétrica das cidades da Jônia, com a legislação de Sólon e com o planejamento urbano reformador de Hipódamo e de Clístenes. ${ }^{132}$

${ }^{132}$ CORNELLI, p. 163. 


\section{A criação religiosa do espaço no direito romano}

Certabant, urbem Romam Remoramne vocarent; omnibus cura viris uter esset induperator.

Exspectant, veduti consul cum mittere signum volt, omnes avidi spectant ad carceris oras, quam mox emittat pictis e faucibus currus: sic exspectabat populus atque ore timebat rebus, utri magni victoria sit data regni.

Discutiam se chamariam a cidade Roma ou Rêmora, A qual dos dois seria imposto o cuidado de todos os homens.

Estavam atentos: como quando o cônsul vai dar o sinal, E todos ansiosos observam a boca do antro Adornado por cuja garganta logo sairá a carruagem. Assim o povo aguardava e temia os sinais

Para qual dos dois seria dada a vitória do grande reino.

Quinto Ênio, Anais, citado por Cícero, Sobre a divinação, I, 48.

Seguimos com os olhos voltados para a Península Itálica, onde tem lugar um importante ritual, com implicações das mais violentas: a fundação de uma cidade no Lácio.

Sobre esse evento, Plutarco (Vida de Rômulo, X), conta que Remo, ao saber que seu irmão fazia um sulco na terra com o arado, para traçar os futuros muros de uma cidade, dirigiu-se até o local, onde começou a ridicularizar e obstruir o trabalho, até o ponto de começar a pular sobre a linha traçada pela charrua e desmanchá-la, o que enfim levou Rômulo a assassinar o próprio irmão.

$\mathrm{O}$ ato de fundação da cidade aparece de modo recorrente relacionado à violência. Diante do caso de Roma, salta à vista o interessante paralelo com a tradição hebraica, pois Caim, tal qual Rômulo, é um fratricida e também o fundador de uma cidade. Caim, קין, qayin, também significa "lança", e está relacionado, por sua raiz, ao verbo que exprime, simultaneamente, as ações de "invejar", "ter ciúme" e "possuir", $q$ nנא'. O invejoso Caim é, naturalmente, também o pioneiro possuidor de um lote da terra, pois foi o primeiro a 
delimitar no solo traçado de uma cidade, à qual deu o nome de seu filho Enoque (cf. Gen. $4: 17){ }^{133}$

Para além dos fratricidas Rômulo e Caim, as tradições antigas dão conta de fundadores parricidas, como Teseu, bem como outros, infanticidas. A persistente atribuição do rito fundacional a homicidas se reporta à concepção da própria fundação da cidade como um ato de violência que, como tal, só pode ser desempenhado por homens violentos, ao mesmo tempo em que clama, em contrapartida, pelo sacrifício humano como o preço a ser pago para se obter a expiação em face da natureza ferida. ${ }^{134}$

Com efeito, o ato de construir é necessariamente uma atitude que se leva a cabo contra a natureza. A simples escolha do local da construção da cidade já implica separá-lo do ritmo do universo natural, razão pela qual Rykwert observa que o ato humano de construir se opõe, pelo fato de ser um processo consciente, ao que fazem os animais quando passam a habitar uma toca ou covil. ${ }^{135}$

Mas penso que não seja simplesmente por conta do caráter consciente da escolha humana de edificar e habitar que se dê a oposição entre o homem e o animal. A verdadeira diferença reside na efetiva modificação do espaço, pois a maior parte dos animais não promove alterações do ambiente habitado, geralmente se abrigando em cavidades naturais.

O caráter inconsciente das ações dos animais apenas é invocado quando é necessário justificar a especificidade da condição humana em face de animais gregários e construtores, como as abelhas. Justificativa que se faz necessária, por exemplo, em Aristóteles, que admite, já no Livro I da Política, que o Estado é uma criação da natureza, pois o homem não pode subsistir fora do corpo político. Ora, se o Estado é uma realidade natural, o que o faz diferente de uma colmeia? O dom da fala, que capacita o homem para a deliberação, dirá Aristóteles, na mesma passagem (1253a).

Não por acaso, os animais que também edificam - ainda que por instinto - são considerados pela cultura popular como seres, ao menos em algum grau, violentos: as abelhas; as formigas; o João-de-barro, cuja lenda, disseminada no interior do Brasil, diz ser a ave capaz de, por ciúme, aprisionar a fêmea no ninho até a morte. Formas um tanto humanas de violência.

\footnotetext{
${ }^{133}$ RYKWERT, pp. 2; 210.

${ }^{134}$ RYKWERT, p. 211.

135 RYKWERT, p. 210.
} 
Ao contrário do que se dá com os animais, o relacionamento do homem com a natureza não se limita a usá-la como suporte para o desempenho contínuo das atividades biológicas necessárias à sobrevivência. A ação do homem sobre a natureza é multiplicadora, no sentido de que permite criar um objeto mais ou menos durável, que pode ser usado como modelo para a confecção de outros objetos. A atividade de edificação de um mundo de coisas humanas é um ato de violência contra a natureza, uma vez que o ser humano se mede com as forças naturais para conseguir apartar do domínio da natureza uma porção de seu espaço e de seus elementos, dando-lhes existência perene. Em sua contínua luta contra o ritmo da natureza, o homem consegue amplificar exponencialmente sua própria capacidade destrutiva por meio do uso de instrumentos, eles próprios um produto dessa dinâmica violenta. Aliás, pode-se dizer que a natureza como um todo é instrumentalizada, pois sua submissão atende sempre a alguma finalidade humana. ${ }^{136}$

Não é raro nos depararmos com notícias sobre experimentos científicos em que a inteligência de variadas espécies de animais é medida a partir de sua capacidade de usar instrumentos.

Com a violência implícita ao ato da fundação, sobrevém um recorrente sentimento de culpa, a ser expiada mediante sacrifícios. É tão forte a correlação entre o sacrifício e a fundação que, em diversas culturas, a própria cidade fundada passa a ser identificada com a vítima. Rykwert enumera os exemplos: os sacrifícios humanos por ocasião da aradura e da construção da casa da família, entre os mais antigos chineses e diversos povos africanos; os dogons, que dispõem as partes de suas aldeias conforme as partes do corpo humano; os hauçás e sua esquematização do universo de acordo com um plano dividido em quatro partes, promovendo divisão semelhante nas suas cidades e nos animais sacrificados nessas ocasiões, que são esquartejados (outrora, eram vítimas humanas). ${ }^{137}$

A fundação da cidade é um ato de sacrifício, no qual a própria cidade se transubstancia em vítima. Os romanos contavam o tempo ab urbe condita, isto é, "desde a fundação da cidade". Sobre essa expressão, cabe lembrar que conditus é não somente o que está fundado e estabelecido, mas também o que está guardado, oculto e sepultado conditus in tumulo. ${ }^{138}$

\footnotetext{
${ }^{136}$ ARENDT, pp. 152-157.

${ }^{137}$ RYKWERT, pp. 211-218.

${ }^{138}$ SARAIVA, verbete Cōndǐtǔs, ă, ǔm.
} 
É praticamente um lugar-comum a divisão em quatro partes do universo (o mapa de Anaximandro?), da cidade (o hieróglifo egípcio para a cidade, um círculo com uma cruz inscrita?) e do corpo sacrificado (os fiéis de variadas denominações cristãs, que fazem a divisão de si próprios em quatro partes, ao persignar-se?).

Ademais do aspecto da violência, o episódio do fratricídio cometido por Rômulo é elucidado com a compreensão do verdadeiro sentido do ato de fundação como um ritual religioso. Sobre isso somos informados em passagem posterior da Vida de Rômulo (XI, 2): a fundação da cidade consistia em uma cerimônia na qual o fundador, com a cabeça coberta pela borda da toga, estabelecia o traçado do espaço urbano com uma charrua, tomando-se todo o cuidado possível para que nenhuma parcela da terra revolvida ficasse para fora do espaço demarcado, o que era assegurado pela posição oblíqua da lâmina do arado e pela assistência do povo, que recolhia a terra eventualmente caída para fora da linha - como a epígrafe deste capítulo demonstra, a cerimônia de fundação era um ato público. A linha traçada com a charrua indicava o lugar em que seriam erguidas as muralhas, daí ser este espaço demarcado dito pomoerium, isto é, post murum. ${ }^{139}$

Os muros da cidade eram dotados de importância religiosa. O muro erguido por ocasião da fundação, como é confirmado pelo testemunho de outras lendas da antiguidade grega e romana, é de altura diminuta, pois se trata de uma construção simbólica. Apenas em momento posterior seriam erguidos os muros defensivos, seguindo as linhas do sulco. As mesmas lendas informam sobre indivíduos que teriam saltado sobre tais fossos ou muros rituais, sendo mortos por isso. Portanto, a zombaria de Remo, que saltava por sobre os sulcos e perturbava o trabalho de Rômulo correspondia a um ato sacrílego, a uma impiedade punível com a morte.

A religiosidade oficial romana estava essencialmente assentada em escrituras sagradas, dentre as quais as principais eram os livros atribuídos ao anão Tages, entidade que, certa manhã, surge repentinamente sob o arado do áugure Tarcão e passa todo aquele dia ditando a este seus preceitos, que constituiriam os etrusca disciplina, os ritos da religião dos etruscos; e as instruções cerimoniais transmitidas pela ninfa Vegoia. Entre os preceitos contidos nesses libri vegoienses, cabe destacar os rituales, conjunto de normas relativas aos ritos da fundação das cidades e consagração de altares e templos, santificação

${ }^{139}$ RYKWERT, pp. 2-3; 62. 
dos muros, distribuição das portas e organização das tribos e dos exércitos e de tudo o mais que diga respeito à guerra e à paz. ${ }^{140}$

Há uma relação de identidade entre cidades e templos que esclarece a aplicação dos preceitos vegoienses a ambos os casos. O conceito de templo que conhecemos, como edificação, remonta ao templum minus, que é uma forma específica daquilo que os romanos denominavam templum, e que abrangia uma noção muito mais extensa do que a de um prédio destinado ao ofício religioso. O templum, originariamente, se tratava de um terreno delimitado por meio de uma espécie de diagrama traçado pelo áugure por ocasião da cerimônia da contemplatio. $\mathrm{O}$ diagrama em questão representava o terreno à frente do qual se colocava o sacerdote no momento daquele ritual. Após o avistamento de um augúrio (inauguratio), o áugure interpretava o sinal, daí extraindo os critérios para a delimitação do espaço sagrado, o qual era estabelecido justamente por meio do diagrama do templum desenhado no solo com uma vara ritual. Tal desenho era rigidamente ajustado em conformidade com os quatro pontos cardeais e tratava de reproduzir na superfície terrestre as divisões celestiais. ${ }^{141}$

A divisão do plano do templum em quatro partes; a obtenção do augúrio por meio da interpretação do conteúdo das vísceras de uma ave. Têm-se aí aspectos do caráter sacrificial dos ritos de fundação, ao qual se aludiu mais acima.

O sulco da charrua apenas era interrompido nos pontos correspondentes aos futuros portões da cidade, pontos nos quais o arado era erguido e carregado, sem tocar o solo, para então voltar a ferir a terra. Os antigos faziam derivar a palavra para os portões, porta, desse ato de carregar (portare) o arado. Muito embora, como nos informa Marky, os portões fossem considerados, juntamente com os muros, res sanctae, no sentido de estarem esses objetos sob a proteção dos deuses, os portões não estavam submetidos ao mesmo regramento religioso dos muros, pois eram via de trânsito de mercadorias e de cadáveres. Seu uso estava sujeito exclusivamente ao regime da jurisdição civil. ${ }^{142}$

Deve-se buscar a exata compreensão do que seja o caráter de sanctum atribuído aos portões e muros da cidade. Encontra-se sua definição no Digesto (I, 8, 8): sanctum est quod ab iniuria hominum defensum atque munitum est. O santo é o que está interdito à ofensa

\footnotetext{
${ }^{140}$ RYKWERT, pp. 4-5.

${ }^{141}$ RYKWERT, pp. 31-38.

${ }^{142}$ MARKY, Thomas. Curso elementar de direito romano. 8 a ed. São Paulo: Saraiva. 1995, p. 40; RYKWERT, pp. $2-3 ; 62$.
} 
dos homens. Mais adiante (I, 8, 9, § 3): proprie dicimus sancta quae neque sacra, neque profana sunt, sed sanctione quadam confirmata, ut leges sanctae sunt (...); quod enim sanctione quadam subnixum est, id sanctum est, et si deo non sit consecratum. "Dizemos propriamente santas as coisas que não são nem sagradas nem profanas, mas que são confirmadas por certa sanção, tal como as leis são sancionadas (...); o que está submetido a alguma sanção, isto é santo, mesmo que não seja consagrado ao deus". 143

Podemos extrair duas informações importantes dessas definições. Em primeiro lugar, resta claro que sanctum é, na verdade, o particípio passado de sancire, "sancionar". É santo aquilo que está protegido por uma sanção, sanctio, que é propriamente a parte da lei que enuncia a pena a ser aplicada a quem a transgredir. Portanto, sancire é geralmente entendido como poenam afficere. Nos princípios do direito romano, a aplicação da pena era um atributo dos deuses, que intervinham por meio da vingança privada. ${ }^{144}$

A segunda informação de relevo é que sanctum não é o mesmo que sacrum. De fato, o santo está no limiar, não é nem sagrado nem profano, mas um intermediário. Neste ponto, é necessário que se abandone a concepção decorrente do entendimento cristão da categoria do sacrum para compreender este termo em seu sentido original, tal qual posto pelo Digesto: sacrum é o oposto de profanum, vale dizer, sacrum é o que está, de algum modo, apartado do convívio humano. O sacrum não faz parte da vivência cotidiana. ${ }^{145}$

Isso nos permite compreender a obscura figura do homo sacer, o indivíduo portador de um signo que o exclui da sociedade dos homens, não incorrendo em ilícito algum aquele que o matar. Contudo, o homo sacer não pode ser morto em sacrifício, pois o sacrificium sacrum officium - é justamente o ato desempenhado pelo sacerdote, sacerdos, *sakro-dhōt$s$, de fazer (*dhe-) a vítima se tornar sacer, retirando-a do mundo humano, com a morte, para pô-la em contato com os deuses. Ora, o homo sacer já está fora do mundo humano em vida, não havendo sentido algum em sacrificá-lo. ${ }^{146}$

Uma das hipóteses que acarretavam para a pessoa a condição de homo sacer era a violação da lei, conforme a fórmula que acompanhava o ato de sancire leges: qui legem violavit, sacer esto. Portanto, a lex, ao se tornar sancta, tem o condão de tornar o conteúdo

\footnotetext{
143 Apud Benveniste, vol. 2, p. 189.

${ }^{144}$ BenVENISTE, vol. 2, pp. 189-190.

145 BenVeniste, vol. 2, p. 190.

${ }^{146}$ BENVENISTE, vol. 2, pp. 188-189.
} 
sancionado algo sacrum. São duas naturezas distintas. O sanctum é o que se põe nos limites do sacrum, a fim de barrar o profanum. ${ }^{147}$

A religião romana está apoiada nos auspicia e nos sacra. Rômulo fundou a cidade segundo a orientação dos auspícios; daí por diante, dedicou-se à guerra e a reunião das sete colinas no interior de uma mesma muralha. Seu sucessor, Numa, o grande legislador da monarquia romana, dedicou-se majoritariamente ao aspecto do sacrum, ao estabelecer o sacerdócio, a forma do culto religioso. Como dizem os próprios romanos, os auspicia descem do céu e são recebidos pelos homens; os sacra são emitidos para o céu, desde a terra. $^{148}$

Ora, Marky, no lugar mencionado, opõe às res sanctae, identificadas como os muros e portas da cidade, as res sacrae, que seriam os templos, que, no dizer do autor, são as coisas diretamente relacionadas ao culto. Porém, como já visto, o local do culto é apenas uma espécie, templum minus, do gênero templum. A própria cidade é um templum, sacra, portanto, enquanto os elementos que a envolvem - muros, portões e leis - estão todos dotados de natureza sancta. Conforme já visto, o ato de fundação está recorrentemente associado ao sacrifício; e a cidade, em muitas culturas, é anatomicamente identificada com a vítima sacrificial, que por sinal é apartada da natureza por meio do ritual, o que também acontece com a cidade fundada. Natural, portanto, que se siga o caráter sacer da cidade como um todo.

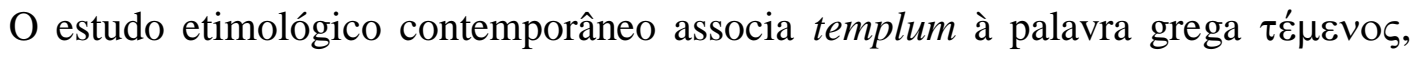
que dá nome a um lugar sagrado delimitado. Este substantivo é derivado do verbo $\tau \varepsilon ́ \mu \nu \omega$, "cortar", "talhar", o que tem sido interpretado como uma indicação de que tais templos fossem originalmente construídos com tábuas de madeira cortadas. ${ }^{149}$ Contudo, a relação entre os templa e a madeira - mais especificamente, com as árvores - é muito mais profunda, fazendo parte inclusive da fórmula de consagração do território demarcado pelo áugure:

Templa tescaque me ita sunto quoad ego caste língua nuncupavero. Olla veter arbos, quirquir est, quam me sentio dixisse, templum tescumque [finito in sinistrum.

\footnotetext{
${ }^{147}$ BenVENiste, vol. 2, p. 190.

${ }^{148}$ DUMÉZIL, pp. 299-306.

${ }^{149}$ RYKWERT, p. 32.
} 
Olla veter arbos, quirquir est, quam me sentio dixisse, templum tescumque [finito in dextrum.

Inter ea conregione, conspicione, cortumione, utque ea rectissime sensi.

Com base nesta fórmula, Varrão chega à conclusão de que as árvores funcionavam como limites do templum. Cornford, que transcreve a fórmula do áugure a partir do testemunho daquele autor latino, vai além ao relacionar a palavra latina para bosque,

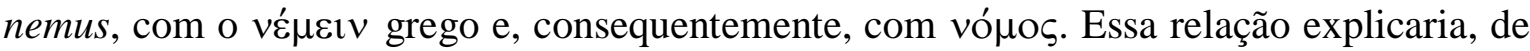
acordo com Cornford, a evolução de Nêmesis desde uma divindade dos bosques até um princípio impessoal de vingança divina, já que a deusa habitava o vépos, um bosquetemplo, lugar sagrado que não poderia ser contaminado pela presença humana profana, não purificada, sob pena de vingança da divindade zelosa contra a transgressão. ${ }^{150}$

A fundação de Roma, em cujo sítio havia um bosque sagrado, corresponde a uma daquelas cerimônias de contemplatio. Segundo a tradição, Rômulo e Remo observaram o voo das aves, augúrio interpretado em seguida pelo sacerdote de acordo com os libri rituales, ao que se seguiu o desenho do diagrama do templum. $\mathrm{O}$ ato de dividir a figura do diagrama em conformidade com as divisões celestes é denominado conrectio, o que nos remete à natureza ritual do rei e as implicações espaciais de suas funções, como se passará a analisar.

Com efeito, Benveniste demonstra etimologicamente o caráter espacial da atuação do rex, título derivado de um tema nominal *rēg-, por meio do qual está relacionado ao grego ỏ $\varepsilon_{\gamma}(\omega$, verbo com o significado de "estender em linha reta". A linha assim traçada pelo rex define uma região, regio, sendo prerrogativa deste indivíduo, mais sacerdote do que líder político, regere fines, ou seja, delimitar, por meio de uma operação mágica, o espaço de uma cidade ou de um templo. ${ }^{151}$

O instrumento usado no traçado da linha reta é a regula, que passa gradativamente a operar não apenas fisicamente, mas em termos mais abstratos, como "regra", o que explica a dualidade assumida pela tradução portuguesa do termo regula em latim ("régua" e "regra"). Com o tempo, rectus passa a qualificar não somente a qualidade da linha

\footnotetext{
${ }^{150}$ CORNFORD, pp. 31-33.

${ }^{151}$ BENVENISTE vol. 2, pp. 11-14.
} 
traçada no solo, como também os limites morais. Ao rectum, que é nosso Direito derectum - corresponde o raihts gótico, e daí o Recht alemão e o Right inglês. ${ }^{152}$

Portanto, Remo foi morto por contaminar, com seu ato de pilhéria, o ofício cerimonial de regere fines conduzido pelo rex Rômulo. Este delimita com a charrua o espaço mediante uma leitura do mundo, possível graças à interpretação dos auspícios.

A religião romana promove a leitura do mundo por meio dos auspícios. Benveniste se dedica à tormentosa questão da etimologia da palavra religião, termo presente em todas as línguas ocidentais modernas, mas originariamente atestado exclusivamente em latim. Muito difundida é a explicação de religio em relação com o verbo ligare, de modo a expressar o senso de obrigação decorrente do sentimento de conexão entre o indivíduo e a divindade, sendo a religião o ofício de religar homem e deus.

Benveniste se opõe àquela explicação, com fundamento na contundente interpretação de Cícero acerca do tema (De natura deorum, II, 28, 72):

Qui autem omnia quae ad cultum deorum pertinerent diligenter retractarent et tanquam relegerent, sunt dicti religiosi ex relegendo ut elegantes ex eligendo, ex diligendo diligente. His enim in verbis omnibus inest vis legendi eadem quae in religioso.

Cícero, como cultor por excelência da língua latina, tem consciência de que eligere e diligere estão etimologicamente ligadas a legere. Como o português não conservou evidente essa relação, a tradução resulta sofrível - mas necessária, a fim de que se esclareça o sentido procurado:

Do verbo reler são ditas religiosas aquelas coisas que retomem com diligência e de algum modo releiam o que pertença ao culto dos deuses; como do verbo eleger são ditas as coisas elegantes; e do verbo diligenciar, as diligentes. Todas essas palavras têm efetivamente o mesmo sentido de ler que há em religioso.

Com apoio nessa importante passagem e em outras razões, de ordem morfológica, Benveniste afasta a relação de religio com ligare em favor de outro verbo, legere. A "leitura" em comento não remete diretamente ao nosso entendimento moderno do ato de ler

152 Benveniste, vol. 2, pp. 14-15. 
algo escrito, mas antes a "recolher", "captar", "tomar". Legere equivaleria a recolher algo, da mesma forma que a negligência, neglectio (nec-lectio) seria um deixar de tomar para si algo que deveria ter sido colhido; e diligentia expressaria o recolher com preferência e especial atenção, daí diligere como "amar", "estimar". Nesse sentido, se à intelligentia corresponde o ato de "recolher mediante uma escolha, reter por meio de reflexão e compreender", pode-se inferir em religio o ato de recolher, a tomada a partir de uma nova escolha. ${ }^{153}$

Essencialmente, portanto, o ato religioso demanda uma operação reflexiva por parte do crente. Em outras palavras, trata-se de uma interpretação subjetiva em face da realidade concreta. Tal caráter subjetivo da religião romana foi sistematicamente combatido pelos primeiros autores cristãos em língua latina, tais como Tertuliano e Lactâncio, que se esforçaram por propagar a já aludida correlação entre religio e religatio. ${ }^{154}$

Com efeito, a interpretação defendida por Benveniste me parece ter o mérito de ajudar a situar a religião tradicional romana no âmbito de outras religiosidades indoeuropeias, como a grega e a hindu, as quais propõem ao crente um esforço de desvelamento do mundo, contrariamente à perspectiva de uma verdade revelada, típica das religiões abraâmicas, entendimento ao qual se coaduna de forma mais adequada o entendimento de religio como religare nos autores cristãos latinos.

De qualquer modo, sempre é válido recordar que é conhecida a relação semântica entre legere e lex. A junção de uma desinência típica do nominativo à forma reconstruída de um provável radical *legg- para legere resultaria em *leggs, daí lex e suas respectivas formas declinadas, dotadas de um $g$ vestigial (legem, legis etc.). A lex originária se refere aos limites condicionantes do objeto. Ovídio faz menção às condições de um lugar, lex loci, bem como ao movimento que governa os astros, qua sidera lege mearent. ${ }^{155}$

A lex romana se encontra imbuída de caráter religioso, sendo regida em sua criação pelos rituais dos augúrios, da mesma forma que se verifica no ato de fundação da cidade. Por questões ideológicas, tende-se hodiernamente a considerar a lex, especialmente no período da República romana, como manifestação solene da vontade do povo. A respeito

\footnotetext{
${ }^{153}$ Benveniste, vol. 2, pp. 268-272.

${ }^{154}$ Benveniste, vol. 2, p. 272.

${ }^{155}$ SARAIVA, verbete Lēx, lēgǐs.
} 
do equívoco subjacente à projeção anacrônica dessa concepção voluntarista do direito aos romanos, Ari Marcelo Solon, com apoio em Hägerström ${ }^{156}$ :

\begin{abstract}
(...) A lei em Roma também se submetia a limites formais decorrentes do direito dos auspícios. As leis contrárias aos auspícios caracterizavam-se como viciadas e nulas, corroborando a íntima vinculação entre ius e fas. De maneira análoga, apresenta-se o conceito de iustus como sinônimo, no direito sagrado, de purus, isto é, puro de qualquer mancha, gozando da benevolência divina: "ius é, na verdade, o poder sobrenatural, caracterizado pela pureza de contaminação de germes da morte, portanto, uma força vital mística. Iustus é, em conformidade a isto, o mesmo que purus, puro de germes da morte". Desta forma, o ius não continha nenhum preceito, mas era uma ordem de poder místico. Ius est, referindo-se às ações dos deuses, significa acarretar benevolência, eliminando os elementos capazes de provocar a ira divina. Ius non est $=$ Nefas significa o contrário: uma ação que provoca a ira divina. Por outro lado, para reforçar a tese de que a legislação em Roma não exprimia a vontade do povo, mas esta mystische göttliche Kraftordnung, aduz-se o argumento de que, por meio da lei, o povo romano poderia inclusive influenciar os deuses, tornando, assim, impossível conceber a lex, não obstante sua forma imperativa, como uma prescrição - a menos que se pudesse imaginar o povo romano dando ordens aos deuses!
\end{abstract}

Os atos religiosos da fundação da cidade e da criação de leis são sempre precedidos pela enunciação de auspícios. Importante ter em consideração o fato de que referidos auspícios não fornecem uma previsão acerca de eventos vindouros, e sim uma confirmação no que toca ao beneplácito divino, a pax deorum, para o ato a ser desempenhado, isto é, para a escolha envolvida na coleta de religio. Portanto, a divinação era voltada ao passado, não para o futuro. ${ }^{157}$

A conformação ao passado é um aspecto comumente aventado para tratar da ideia romana de autoridade. Etimologicamente, é sabido que a essa noção de auctoritas, tão importante para o entendimento do direito e das práticas políticas dos romanos, efetivamente se vinculam vocábulos tais como auspicium e augur. O liame entre todos aqueles termos se deve à raiz comum, que originou também o verbo augere. Esse verbo é geralmente traduzido por "aumentar", que efetivamente corresponde ao seu uso no latim clássico. É a tradução veiculada, entre nós, por Ferraz Jr., com apoio na opinião de Arendt. Para esses autores, com base naquela acepção, a auctoritas consistiria em uma responsabilidade política quanto à ampliação do ato fundador. O portador da auctoritas, nesse sentido, seria alguém politicamente legitimado a aumentar a fundação de Roma, em

${ }^{156}$ Solon, Ari Marcelo. Dever jurídico e teoria realista do direito. S. ed. Porto Alegre: Sergio Antonio Fabris. 2000, pp. 21-22.

${ }^{157}$ RYKWERT, p. 95. 
conformidade com o que fora estabelecido por Rômulo no início dos tempos, ab urbe condita. ${ }^{158}$

Contudo, a auctoritas é um atributo do auctor, e a ação do autor consiste em iniciar algo até então inexistente, e não em dar continuidade a uma realidade anterior. A atividade do autor consistia em alterar a realidade mediante a introdução de sua obra, algo novo, original. Auctoritas diz respeito à ideia religiosa de criação, como uma manifestação produtiva na materialidade do mundo. A auctoritas é a própria capacidade fundadora. A ideia de aumento corresponde a um sentido secundário da raiz. Ao lado de augmentum, surgem auctoritas e auxilium, e também Augustus, que é este indivíduo dotado de incríveis poderes mágicos: fazer surgir a vegetação e as leis. ${ }^{159}$

Diz Benveniste:

Le sens premier de augeo se retrouve par l'intermédiaire de auctor dans auctoritas. Toute parole prononcée avec l'autorité determine un changement dans le monde, crée quelque chose; cette qualité mystérieuse, c'est ce que augeo exprime, le pouvoir qui fait surgir les plantes, qui donne existence à une loi. Celui qui est auctor, qui promeut, celui-là seul est pourvu de cette qualité que l'indien appele ojah.

On voit que "augmenter" est un sens secondaire et affaibli de augeo. Des valeurs obscures et puissantes demeurent dans cette auctoritas, ce don reservé à peu d'hommes de faire surgir quelque chose et - à la lettre - de produire à l'éxistence. ${ }^{160}$

A prática dos auspícios está diretamente relacionada a esse intento de inovação da realidade. Diz Rykwert, acerca dessa questão, que a fundação de uma nova cidade equivaleria à instauração de uma nova religiosidade, consistindo em evento a ser desempenhado dentro de limites estritos de atuação, não restando muito espaço à discricionariedade dos fundadores - embora estes não raro tentassem manipular os augúrios para evitar uma resposta divina inconveniente... ${ }^{161}$

Com isso, impõe-se a questão: tratando-se de um ato regido pelos sinais divinos, em que medida os desígnios humanos eram levados em conta na determinação do sítio e das condições gerais da nova povoação? Afinal, como visto anteriormente, um dos traços distintivos da ação humana de edificar estava no caráter consciente da escolha do sítio.

\footnotetext{
${ }^{158}$ BenVEniste, vol. 2, pp. 148-149. FerRAZ JR., pp. 60-61.

${ }^{159}$ BENVENISTE, vol. 2, p. 150.

${ }^{160}$ BENVENISTE, vol. 2, p. 151.

${ }^{161}$ RYKWERT, pp. 94-95.
} 
Veja-se o que diz Cícero, a respeito da fundação levada a cabo por Rômulo ${ }^{162}$ :

\begin{abstract}
Quanto ao lugar para a Cidade, que deve ser planeado com todo o cuidado por quem tenta lançar a semente de um Estado duradouro, fez uma escolha espantosamente apropriada. Pois nem a levou para junto do mar, coisa que com aquele poder militar lhe era facílimo, nem avançou para o domínio dos Rútulos ou dos Aborígenes, ou para uma fundação na foz do Tibre, sítio onde muitos anos depois o rei Anco estabeleceu uma colônia. Mas este varão dotado de excelsa prudência teve a visão de compreender que a localização no litoral não é a mais conveniente para cidades destinadas a serem o centro de impérios duradouros, sobretudo porque as cidades marítimas estão expostas, não só a perigos variados, mas até desconhecidos.
\end{abstract}

Sem dúvida, tais fatores de ordem prática terão concorrido para a localização da cidade a ser fundada. No entanto, essas questões não sobressaíam em face das motivações de ordem religiosa. Em muitos casos, na verdade, o que se observa é que as questões rituais são tratadas de maneira extremamente minuciosa, segundo uma orientação racional, ao passo que os problemas eminentemente técnicos eram resolvidos de maneira vacilante, por tentativa e erro, sem uma abordagem racional apropriada. Embora os Antigos tenham desenvolvido fartamente o seu acervo de conhecimentos científicos, tiveram dificuldade em associar ao conhecimento teórico as aplicações técnicas que lhes seriam consequentes. O campo da técnica, deste modo, não era guiado por uma mentalidade científica, mas indutivamente, pelas necessidades práticas, e racionalmente, pelo ritual. ${ }^{163}$

Importante que se frise esse ponto, porque os modernos comumente tentam submeter o sentido religioso dos rituais e crenças a motivações de ordem prática e racional, quando na verdade são estas que se conformam àqueles, não raro amalgamando-se. O que faz Cícero no trecho acima transcrito é articular as questões práticas com as razões verdadeiramente fortes para a escolha do local, que são aquelas dadas pelo mito da fundação, previamente apresentado pelo autor. ${ }^{164}$

Um exemplo da conciliação entre explicações racionais e religiosas provém de Plutarco. Em sua Vida de Péricles, o historiador conta que o político ateniense teria trazido de sua propriedade rural uma cabeça de carneiro dotada de um único chifre, a qual foi submetida ao exame de Lâmpon, um adivinho, e do filósofo Anaxágoras. O adivinho vaticinou que aquele único chifre forte no meio do crânio do animal sinalizava que o

\footnotetext{
${ }^{162}$ Cícero, De re publica, II, 3.5, apud PEREIRA M H R, vol. 2, pp. 11-12.

${ }^{163}$ RYKWERT, pp. 8-9.

${ }^{164}$ RYKWERT, pp. 9-10
} 
governo da cidade seria conquistado pela facção daquele em cujas terras houvesse nascido a criatura. Por seu turno, Anaxágoras partiu o crânio, demonstrando aos demais a má formação do cérebro do carneiro, que não ocupava totalmente o espaço natural do encéfalo, havendo uma cavidade vazia junto à raiz do chifre único, o que apontava o filósofo como causa desta anomalia.

Para Plutarco, ambas as explicações são aceitáveis, pois Anaxágoras demonstrara a causa do prodígio, enquanto Lâmpon indicara a finalidade do ocorrido, o que Plutarco dá como comprovado pela definitiva vitória subsequente da facção de Péricles sobre a de Tucídides na disputa pelo controle dos negócios da cidade. Com isso, Plutarco assume uma posição defensiva tanto em relação aos que consideram o pensamento científico como blasfemo, por denegar as explicações religiosas, quanto em relação aos que acusam a religião de irracionalidade.

Dessa forma, vê-se que um argumento desligado do âmbito ritual era tomado como uma explicação entre todas as outras possíveis (o que inclui os aspectos mágicos e religiosos). Os modernos sempre consideram os feitos dos antigos em termos econômicos, ambientais e estratégicos, mas a verdade é que Cícero jamais teria sobreposto tais aspectos às indicações dadas pelos augúrios. Miscelo, fundador mítico de Crotona, retorna a Delfos para dizer ao oráculo que havia encontrado um sítio que lhe pareceu preferível àquele indicado pela divindade. Foi então repreendido, a fim de que não perseguisse o que não fora ordenado pelo desígnio divino, contentando-se com a indicação dada pelo oráculo para o local da cidade, pois do contrário apenas resultaria desgraça. ${ }^{165}$

Há na literatura muitos exemplos conhecidos de recomendações práticas de autores gregos e romanos sobre a escolha do sítio para a construção das cidades. Por exemplo, o arquiteto romano Vitrúvio aduz uma série de pormenores referentes à salubridade, que considera a qualidade prioritária a ser perseguida na escolha do lugar: o sítio deve ser elevado, nem úmido e nem excessivamente exposto às geadas; o clima deve ser temperado; não deve haver pântanos nas imediações; há que se evitar a exposição aos ventos quentes, de modo que as ruas da nova cidade devem ser dispostas em direção oblíqua relativamente aos ventos mais fortes, a fim de que estes se choquem com as paredes, dispersando-se. Entretanto, há autores de períodos posteriores, como Oribásio, responsável pela revisão e publicação dos textos do médico e filósofo Galeno, que defendem exatamente o contrário,

${ }^{165}$ RYKWERT, pp. 10-11. 
isto é, que os ventos devam correr livremente entre as ruas, em função do arejamento da cidade. ${ }^{166}$

Um catálogo exaustivo de critérios a serem observados na escolha do sítio urbano é oferecido pelo Livro VII da Política de Aristóteles. Ocorre que esse tipo de prescrição sobre o sítio urbano deve ter sido considerado verdadeira excentricidade, pois invariavelmente contrariava o tipo de lugar dado pelas indicações do oráculo ou do augúrio. Muitas cidades - até hoje habitadas - foram edificadas em lugares que seriam considerados insalubres, de acordo com os dogmas dos escritos médicos. Por todos, cite-se o exemplo de Roma, fundada defronte a um pântano desgraçadamente infestado de malária. ${ }^{167}$

Não há nenhuma indicação segura, portanto, quanto à efetiva adoção de critérios racionais para a escolha do lugar da nova cidade. As prescrições literárias soam como teorizações ex post facto, não tendo sido realmente levadas em consideração. Quando muito, costumava-se justificar o acerto da localização em termos comerciais e militares (como demonstra a passagem mencionada de Cícero), sempre para corroborar as verdadeiras razões, concernentes à religião. A incidência de sol e de ventos não era uma razão comumente lembrada pelos habitantes. ${ }^{168}$

Por outro lado, esperava-se que o desempenho dos rituais da fundação da cidade propiciasse força e fertilidade. Atrelava-se um boi e uma vaca ao arado que delimitava os muros, seguindo o macho do lado de fora da linha e a fêmea do lado de dentro, para que os homens fossem temíveis em face do inimigo externo e as mulheres fecundas na cidade. Não deve causar estranhamento a busca de um valor eminentemente rural por meio da cerimônia de fundação de uma cidade, porque inexistia então a oposição entre o rural e o urbano. A maior parte da população da cidade recentemente fundada certamente se dedicava às atividades agrícolas, como o provam os etruscos, primeira civilização urbana da Itália e exímios agricultores. Os romanos nunca restringiram a noção política de sua cidade ao espaço urbano, pois o ager publicus era considerado parte do Estado romano. $\mathrm{O}$ campo cultivado se encontra integrado aos valores da cidade, sendo importante arar e preparar a terra em que se vai erguer algo novo. 169

\footnotetext{
${ }^{166}$ RYKWERT, pp. 24-25.

${ }^{167}$ RYKWERT, pp. 23-26.

168 RYKWERT, p. 26.

169 ARENDT, p. 102; RYKWERT, pp. 158-159.
} 
Plenamente conscientes dessas implicações, os antigos quiseram ligar etimologicamente urbs, a cidade, a urvum, palavra para a curva desenhada pela relha do arado, embora o mais provável seja que a palavra urbs tenha origem etrusca, tendo o significado de "linha circundante", relacionado a orbis, "globo" ou "universo", etimologia que também já havia sido cogitada pelos próprios romanos. ${ }^{170}$

Portanto, o arado, no contexto ritual romano - e na mitologia de diversos outros povos indo-europeus -, é tido como um símbolo da fertilidade, relacionado ao falo e ao chifre do touro. Conforme anteriormente relatado, Tages, a entidade que estabelecera os Etrusca disciplina, era ele próprio nascido da terra após a abertura do sulco por um arado. Ao mesmo tempo, é um símbolo antigo da justiça, presente nas formas de prova das ordálias germânicas.

A oposição entre as esferas do urbano e do rural é tardia. No entanto, é bem marcada a dicotomia indo-europeia entre o campo não cultivado, ainda não integrado à

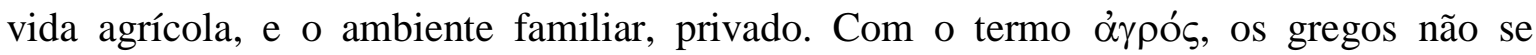
referem simplesmente ao campo, mas ao campo inculto, entendido como um espaço

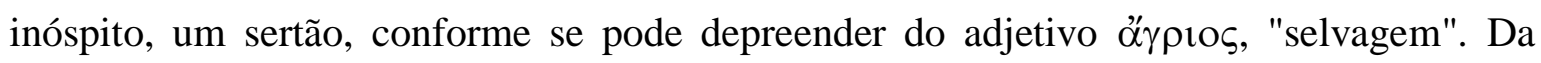
mesma maneira, em latim, é conhecida a oposição entre a realidade que integra o domus, (a ser entendido como o ambiente de relações governado pelo chefe da família, dominus, e não com a construção física da casa) e o ager, o campo. À qualidade do que é domesticus opõe-se o rusticus (*rowestikos). O boi que puxa o arado voltado para fora da linha divisória simboliza a força que se deve voltar contra o inimigo natural, aquele que está fora dos limites - o forasteiro - além dos campos, per-agrum: o peregrinus, o estrangeiro, com quem o romano lida por meio da guerra ou do ius gentium. ${ }^{171}$

Desse modo que o termo cives, antes usado simplesmente para designar o habitante da cidade, passa a ser usado em oposição ao peregrinus. Apenas os integrantes da civitas podem conviver sob o ius civile. Civitas passa gradualmente a ser a palavra usada para designar a cidade como corpo político, em correspondência ao termo grego $\pi$ ó $\lambda 1 \varsigma$, ao passo que a antiga palavra urbs é redefinida em contraposição ao rusticus, ao agrícola.

\footnotetext{
170 ARENDT, p. 73; RYKWERT, p. 157.

${ }^{171}$ Benveniste, vol. 1, pp. 293-314.
} 


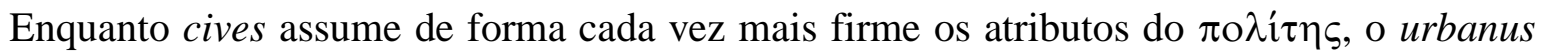
passa a caracterizar o "refinado" em face do habitante do campo. ${ }^{172}$

${ }^{172}$ BenVeniste, vol. 1, p. 367. 


\section{Conclusão}

Esta investigação se iniciou com o espanto decorrente da percepção de que as palavras usadas pelos povos indo-europeus para descrever as atividades relativas ao direito não são derivadas de alguma raiz comum que se refira a esse campo semântico. Este vocabulário tem sua origem em alguns radicais diferentes, que têm em comum o fato de designarem a ação criativa ou manipulativa de aspectos materiais, voltada para a organização do espaço físico.

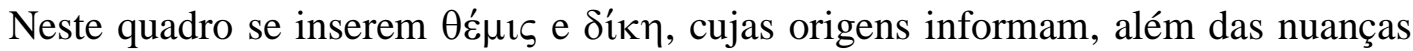
de seus significados espaciais, a evidência da mudança de um paradigma intrafamiliar para um cenário formado por várias famílias reunidas, que interagem entre si. A atividade de dizer o direito, em razão das alterações sociais que instauram a condição interfamiliar da alteridade, consiste em apontar os limites físicos objetivos entre os sujeitos.

Nas origens, ignora-se qualquer ideia ética da justiça, tal como a concebemos. O direito lida com indicações sobre o espaço. Carl Schmitt compreendeu que a história de vó $\mathrm{o}_{\mathrm{o}}$ não tem prosseguimento no conceito moderno de lei, um texto que veicula um enunciado normativo que o autor alemão acusa de ser mais dirigido aos procedimentos concernentes à administração do Estado do que à realidade da vida. Schmitt relata a história do vó $\mu$ o como um nehmen, como a tomada da terra.

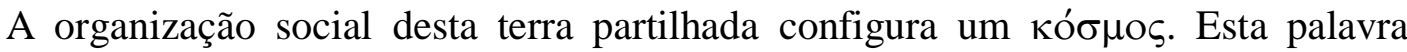
evolui desde um sentido puramente funcional e estético para uma noção política e um conceito filosófico, que busca enquadrar a cidade no sentido geral da natureza. A cidade passa a ser pensada segundo os padrões da nova racionalidade descoberta no universo; não é a filosofia que extrai a racionalidade da política, como pensam muitos historiadores. O acesso à racionalidade da natureza é aprendido pelos filósofos com os arquitetos. Ao mesmo tempo, a filosofia toma das legislações e da organização urbana muitos elementos que viabilizam sua descrição do universo, tais como a valorização do aspecto da centralidade no espaço. 
Em uma $\pi$ ódıৎ onde vigora a isonomia, não é um caudilho, mas a própria lei que ocupa o espaço central, o que denota a forte função simbólica da legislação epigráfica, que representa a vitória da nova ordem sobre o domínio das antigas famílias aristocráticas, o que também é evidenciado pela lareira pública, oposta a todas as lareiras das famílias, separadas entre si e do espaço público pelos muros das leis.

Clístenes reorganizou o espaço e, com isso, o tempo, para promover a isonomia em detrimento da antiga organização tribal. Encorajado pelo sucesso político dos pitagóricos, o planejamento urbano pensado por Platão pretendeu devolver o caráter religioso do arranjo, voltando a submeter a cidade ao universal, o que já estava presente no pensamento político e urbanístico de Hipódamo.

Por fim, Roma nasce da delimitação do espaço com o arado. O rei é responsável por traçar os retos limites, atividade que pressupõe a auctoritas, que é a capacidade religiosa de criar. A religião é um ato de leitura do mundo, atividade que tem na lex um de seus produtos. Os muros e as leis são santos, uma vez que sua sanção protege a sacralidade do ambiente urbano, uma terra violentamente apartada da natureza. O campo do entorno da cidade está a esta integrado, o que é evidenciado pela exaltação do valor rural da fertilidade no ato da fundação. Os estrangeiros são aqueles que estão além do campo, os peregrini, com os quais só se pode tratar por intermédio do ius gentium.

Os estudos linguísticos e filológicos mostram-se muito proveitosos para a pesquisa em direito, área notável por carecer de integração no plano geral dos estudos clássicos, uma vez que promovem a atualização do instrumental de análise e reflexão sobre a origem das instituições e sua continuidade histórica, o que permite excluir anacronismos de interpretação, ao mesmo tempo em que reconhece o direito como um fenômeno cultural, por meio de uma compreensão dialógica. Ademais, tal perspectiva tem o mérito de evitar que o pesquisador perca o sentido das origens e reduza o fenômeno à sua dimensão tecnológica moderna, alienando-se.

Evidentemente, a abordagem não se reduz a suas ferramentas. A análise linguísticofilológica propiciou o acesso a reflexões verdadeiramente atinentes a uma filosofia do direito, ao permitir questionar a situação do valor da justiça na operação do direito, bem como repensar a lei, no que se refere às suas funções e à sua relação com a política. De outro lado, sedimenta-se a via para o estudo do pensamento de autores contemporâneos 
cuja obra é influenciada pelas categorias ora estudadas, dentre os quais cabe destacar Axel Hägerström e as figuras antagônicas de Hans Kelsen e Carl Schmitt.

A compreensão hodierna do direito é bem diversa do sentido do arranjo espacial que ora se apresenta, o que faz com que muitas vezes não consigamos compreender o direito antigo. Ainda que preponderantemente dedicados aos estudos históricos, muitos juristas sustentam uma continuidade ilusória entre nossas instituições e aquelas dos antigos, o que acarreta o risco da petição de princípio, problema tão comum na pesquisa histórica.

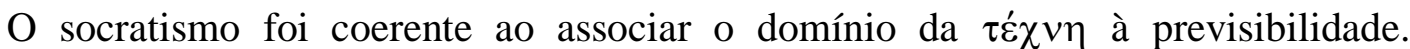
Modernamente, o pensamento técnico de manipulação da natureza, que informou a atividade do legislador antigo, foi alçado à esfera política propriamente dita, o que traz a função legiferante a primeiro plano, em detrimento do discurso. Em substituição às práticas antes tidas como eminentemente políticas, a prevalência legislativa não se presta a delimitar o espaço não violento do exercício da liberdade política essencialmente imprevisível, mas, ao contrário, a viabilizar a previsibilidade total, que trouxe em seu bojo a subversão da relação entre política e liberdade, enquanto o Estado passa também a deter a prerrogativa do monopólio da violência. 


\section{Bibliografia}

ARENDT, Hannah. A condição humana. 10ª ed. Rio de Janeiro: Forense. 2007.

ARISTÓTELES. Politics. S. ed. Cambridge: Harvard. 2005.

ArnaOutoglou, Ilias. Leis da Grécia antiga. 1ª ed. São Paulo: Odysseus. 2003.

BENVENISTE, Émile. Le vocabulaire des institutions indo-européennes. S. ed. Paris: Minuit. 1969. 2 vols.

CAMBraiA, César Nardelli. Introdução à crítica textual. $1^{\text {a }}$ ed. São Paulo: Martins Fontes. 2005.

Clackson, James. Indo-European linguistics: an introduction. $1^{\text {st }}$. ed. Cambridge: Cambridge University. 2007.

COPLeSTON, Frederick. Historia de la filosofía. 1ª ed. Barcelona: Ariel. 2007. Vol. 1.

CORNELli, Gabriele. Refundar a cidade: do projeto filosófico-político das cidades pitagóricas à utopia projetual da República de Platão. In: XAVIER, Dennys Garcia. CORNELl, Gabriele (orgs.). A República de Platão: outros olhares. s. n. São Paulo: Loyola. 2011. 
CORNFORD, F. M.. From religion to philosophy: a study in the origins of Western speculation. $1^{\text {st }}$. ed. Princeton: Princeton University. 1991.

DIELS, Hermann. KRANZ, Walter. Die Fragmente der Vorsokratiker Griechisch und Deutsch. 5. Auf. Berlin: Weidmannsche Verlag. 1935. 2 vols.

DuMÉZIL, Georges. Mythe et épopée I. II. III. $1^{\text {ère }}$.éd. Paris: Gallimard. 1995.

Eves, Howard. Introdução à história da matemática. 5a ed. Campinas: Unicamp. 2011.

FERRAZ JR., Tércio Sampaio. Introdução ao estudo do direito: técnica, decisão, dominação. $4^{\mathrm{a}}$ ed. São Paulo: Atlas. 2003.

Fustel De Coulanges, Numa-Denis. A cidade antiga. $4^{\text {a }}$ ed. São Paulo: Edipro. 2009.

GAGARIN, Michael. Early greek law. $1^{\text {st }}$. ed. Berkeley: University of California. 1989.

HAHN, Robert. Anaximander and the architects: the contributions of Egyptian and Greek architectural technologies to the origins of Greek philosophy. $1^{\text {st }}$. ed. New York: State University of New York. 2001.

HeIDEgGer, Martin. La sentencia de Anaximandro. In: Caminos de bosque. $1^{\mathrm{a}}$. ed. Madrid: Alianza. 2008. pp. 239-277. 
Heródoto. The History of Herodotus. In: Hutchins, John Maynard (org.). Great books of the western world. $1^{\text {st }}$. ed. Chicago: Britannica. 1952. vol. 6.

Hesíodo. Theogony. Works and days. Testimonia. S. ed. Cambridge: Harvard. 2006.

HöLKESKAMP, Karl-Joachim. (In-)Schrift und Monument. Zum Begriff des Gesetzes im archaischen und klassischen Griechenland. In: Zeitschrift für Papyrologie und Epigraphik, Bd. 132 (2000), pp. 73-96, disponível em http://jstor.org/stable/20190691 (Acessado em 09/11/2011 11:17).

HOMERO. Iliad. S. ed. Cambridge: Harvard. 1999. 2 vols. Odissey. S. ed. Cambridge: Harvard. 1995. 2 vols.

JAEGER, Werner. Paidéia: a formação do homem grego. $3^{\mathrm{a}}$ ed. São Paulo: Martins Fontes. 1994.

KAHN, Charles H.. Anaximander and the origins of Greek cosmology. s. ed. Indianapolis: Hackett. 1994.

A arte e o pensamento de Heráclito. S. ed. São Paulo: Paulus. 2009.

Kelsen, Hans. A ilusão da justiça. 4a ed. São Paulo: Martins Fontes. 2008. 
KIRK , G. S. RAVEn, J. E. Schofield, M. Os filósofos pré-socráticos. $6^{\mathrm{a}}$ ed. Lisboa: Calouste Gulbenkian. 2008.

Konstan, David. A amizade no mundo clássico. $1^{\text {a }}$ ed. São Paulo: Odysseus. 2005.

LEPARGNEUR, Hubert. Introdução aos estruturalismos. S. ed. São Paulo: Herder. 1972.

MARKy, Thomas. Curso elementar de direito romano. $8^{\text {a }}$ ed. São Paulo: Saraiva. 1995.

PEREIRA, Isidro. Dicionário grego-português e português-grego. $8^{\mathrm{a}}$ ed. Apostolado da Imprensa: Braga. 1998.

PereIRA, Maria Helena da Rocha. Estudos de História da Cultura Clássica. S. n. Lisboa: Calouste Gulbenkian. 1984. 2 vols.

PERROT, Jean. La linguistique. $2^{\text {ème }}$. éd. Paris: Presses universitaires de France. 1957.

Platão. The dialogues. Seventh letter. In: Hutchins, John Maynard (org.). Great books of the western world. $1^{\text {st }}$. ed. Chicago: Britannica. 1952. vol. 7.

PlutARCO. Lives. S. ed. Cambridge: Harvard. 2005.

Robertson, D. S. Arquitetura grega e romana. $1^{\text {a }}$ ed. São Paulo: Martins Fontes. 1997. 
RYKWERT, Joseph. A ideia de cidade. S. ed. São Paulo: Perspectiva. 2006.

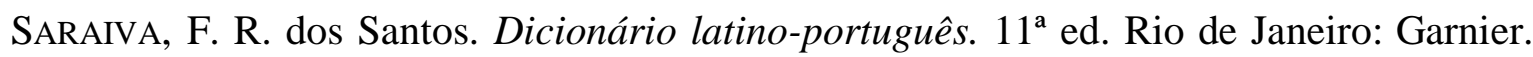
2000.

SchmitT, Carl. El nomos de la tierra en el derecho de gentes del "jus publicum europaeum". S. ed. Buenos Aires: Struhart. 2005.

Solon, Ari Marcelo. Dever jurídico e teoria realista do direito. S. ed. Porto Alegre: Sergio Antonio Fabris. 2000.

Direito e tradição: o legado grego, romano e bíblico. S. ed. Rio de Janeiro: Elservier. 2009.

THOMAS, Rosalind. Letramento e oralidade na Grécia antiga. $1^{\text {a }}$ ed. São Paulo: Odysseys. 2005.

VERNANT, Jean-Pierre. Mito e pensamento entre os gregos: estudos de psicologia histórica. $2^{a}$ ed. São Paulo: Paz e Terra. 2008.

VILLEY, Michel. Filosofia do direito: definições e fins do direito: os meios do direito. $2^{\mathrm{a}}$ ed. Martins Fontes: São Paulo. 2008.

ZARMANIAN, Thalin. Ordnung und Ortung/order and localization. In: LEGG, Stephen (ed.). Spatiality, sovereignty and Carl Schmitt: geographies of the nomos. $1^{\text {st }}$. ed. London: Routledge. 2011. 
ZOJA, Luigi. História da arrogância: psicologia e limites do desenvolvimento humano. S. ed. São Paulo: Axis Mundi. 2000. 